\title{
RESUMOS DE DISSERTAÇÕES DE MESTRADO E TESES DE DOUTORADO APRESENTADAS NA FACULDADE DE MEDICINA DE RIBEIRÃO PRETO - USP DE JULHO A DEZEMBRO DE 2002 EM SUAS DIFERENTES ÁREAS DE CONCENTRAÇÃO
}

\author{
BIOLOGIA CELULAR E MOLECULAR
}

\section{TRANSFERRINA DA RETINA DE COELHOS: ESTUDO BIOQUÍMICO E IMUNOHISTOQUÍMICO}

\author{
Maria Laura Pinto Rodrigues \\ Orientador: Prof. Dr. Eduardo Miguel Laicine \\ Tese de Doutorado apresentada em 22/10/2002
}

O objetivo deste estudo foi verificar o papel da retina neural de coelho como fonte de transferrina para vítreo. Explantes de retina neural foram cultivados na presença de ${ }^{35} \mathrm{~S}$-metionina e os extratos dos explantes e dos meios de incubação foram submetidos à imunoprecipitação com anticorpo anti-transferrina e os imunoprecipitados processados para eletroforese em gel de poliacrilamida-SDS seguidos de fluorografia. RNAm de transferrina da retina foi examinado através da técnica de RT-PCR seguida ou não de clonagem, com posterior seqüenciamento. Além disso in toto ou cortes histológicos espessos da parede da câmara vítrea foram processados para o exame imunohistoquímico de transferrina através de microscopia confocal. Os resultados obtidos permitiram concluir que: i) a metodologia utilizada para o cultivo de explantes de corpo ciliar-íris, desenvolvida neste laboratório, mostrou-se também adequada para o cultivo de explantes de retina, possibilitando a obtenção de marcação metabólica eficiente de proteínas para cultivos de até 16 horas: ii) ocorre a síntese de uma transferina aparentemente não secretória em porções de retina periférica desprovida de raios medulares, com peso molecular cerca de $3 \mathrm{kDa}$ menor que a transferrina do vítreo; iii) explantes de retina periférica orientados com fotorreceptores voltados para o meio de cultivo sintetizam e secretam transferrina, sendo esta a primeira evidência de secreção de transferrina por explantes de retina: iv) as regiões centrais da retina sintetizam e secretam transferrina, provavelmente à custa de astrócitos localizados junto aos vasos sanguíneos presentes nesta região; v) o RNAm de transferrina de retina periférica não apresentou diferenças estruturais significativas em relação ao RNAm de transferrina de fígado, a não ser por uma trinca de nucleótideos a mais, ao que tudo indica, sem repercussões na estrutura e no destino celular desta proteína. Portanto, não foram encontradas alterações estruturais na mensagem que pudessem explicar a diferença de peso molecular detectada, pelo menos quanto as regiões do RNAm de transferrina analisadas até aqui; vi) foi demonstrada a presença de transferrina intracelular nos fotorreceptores, nas células de Muller e nas pequenas células gliais da camada de fibras nervosas, além de outros tipos de neurônios, não identificados, encontrados na retina; vii) os resultados dos experimentos conduzidos neste trabalho sugerem que os fotorreceptores sejam capazes de sintetizar e secretar transferrina; viii) o estudo imunohistoquímico demonstrou, também pela primeira vez, a presença de transferrina na matriz interfotorreceptora.

\section{ESTUDO NEUROANATÔMICO E PSICOFARMACOLÓGICO DO DUPLO ELO GABAérgico ESTRIADO-NIGRO-TECTAL, DE CONEXÕES INTRAMESENCEFÁLICAS E DA INFLUÊNCIA DESSAS VIAS SOBRE O COMPORTAMENTO DE DEFESA ELICIADO POR ESTIMULAÇÃO DO COLÍCULO INFERIOR}

\section{Lissandra Castellan Baldan}

Orientador: Prof. Dr. Norberto Cysne Coimbra

Dissertação de Mestrado apresentada em 24/10/2002
A estimulação elétrica e química de algumas estruturas mesencefálicas, tais como a substância cinzenta periaquedutal dorsal (SCPd), as camadas pro- 
fundas do colículo superior (CPCS) e o núcleo central do colículo inferior (NCCI) eliciam respostas defensivas, associadas ao medo, que muito se assemelham àquelas que caracterizam a síndrome do pânico em humanos. A substância negra, rica em neurônios GABAérgicos, recebe aferências também GABAérgicas provenientes do corpo estriado e se projeta para o mesencéfalo dorsal, mais cranialmente, modulando o substrato neural do medo no colículos superior e SCPd.

O objetivo deste trabalho foi investigar se essas conexões GABAérgicas nigro-tectais também se estendem ao substrato aversivo do cálculo inferior de ratos, determinando sua influência sobre a modulação de respostas aversivas eliciadas por estimulação elétrica do teto mesencefálico dorsal, situado caudalmente. Também foi estudada a neuroanatomia de conexões entre o núcleo central do colículo inferior e as colunas dorsais e ventrais posteriores da substância cinzenta periaquedutal. A via foi traçada com o neutroçador fluorescente "fast blue", de captação e transporte retrógrado, microinjetado no núcleo central do colículo inferior (NCCI) e com o biodextran, um neurotraçador, anterógrado, microinjetado na substância negra, parte reticulada (SNpr) ou no NCCI. Os efeitos da diminuição de atividade dessa via foram estudados, através de lesões eletrolíticas e neuroquímicas (com ácido ibotênico) da substância negra, parte reticulada.

O neurotraçamento retrógrado mostrou células neuroniais localizadas na substância negra, parte reticulada que se projetam ipsi e contralateralmente ao núcleo central do colículio inferior. Essa conexão nigro-tectal foi confirmada pelo neurotraçameno anterógrado, que mostrou fibras axônicas no núcleo central de colículo inferior, após a microinjeção de biodextran na substância negra, parte reticulada. Tanto a lesão eletrolítica como a lesão neuroquímica da substância negra, parte reticulada, sensibilizaram o teto mesencefálico à estimulaçao aversiva. $\mathrm{O}$ estudo das conexões intramesencefálicas, estudadas através da microinjeção iontoforética de biodextran no núcleo central do colículo inferior, permitiu a identificação de uma via rica em fibras varicosas conectando o NCCI, às colunas dorsomediais e laterais mais posteriores da substância cinzenta periaquedutal (SCP).

\section{TRAÇANDO AS ORIGENS DE AMOSTRAS MONOFÁSICA SALMONELLA ENTERICA i 4, 5,} 12: I - : SIMILARIDADE GENÉTICA COM S. ENTERICA TYPHIMURIUM

\author{
Ana Isabela Lopes Sala \\ Orientador: Prof. Dr.Marcelo Brocchi \\ Dissertação de Mestrado apresentada em 25/10/2002
}

Salmonella enterica é um importante patógeno para humanos, causador de infecções que vão desde gastroenterites localizadas a infecções sistêmicas graves (Salyers \& Whitt, 1994). Esta espécie é subdividida em sorovariedades, sendo conhecidas mais de 2.300 . Typhimurium e Enteritidis são as sorovariedades mais frequientemente isoladas em fezes diarréicas de pacientes sofrendo infecções intestinais e/ou sistêmicas. No estado de São Paulo, particularmente na região de Ribeirão Preto, além das sorovariedades mencionadas acima, uma possível nova sorovariedade tem sido isolada com frequiência. Tais isolados apresentam características sorológicas e fisiológicas semelhantes à $\mathrm{S}$. enterica Typhimurium (ST), mas não apresentam a variação de fase flagelar, característica desta última sorovariedade (S. enterica I 4, [5], 12:i:-). Resultados prévios indicam que esta última sorovariedade é mais virulenta que ST (Dra. Sueli Fernandes, Instituto Adolfo Lutz de São Paulo, comunicação pessoal), podendo ser originária de $\mathrm{S}$. enterica sorovariedade Typhimurium (composição antigênica I 4, [5], 12:i:1,2) ou Lagos (I 4, [5], 12:i:1,5). Além disso, os isolados S. enterica I 4, [5]. 12:i:- (Sti) podem ser derivados de um único clone ou de diferentes clones que sofreram mutação que levou a não variação de fase flagelar em eventos diferentes e em épocas distintas. Recentemente, Ikeda et al. (2001) demonstraram que mutantes de S. enterica capazes de expressar somente o antígeno de fase flagelar classe 1, que é o caso das amostras Sti, são mais aptos a causar infecção sistêmica do que mutantes que expressam o antígeno de classe 2. Dada a importância epidemiológca destes isolados, sua associação com infecções graves em humanos (infecções enterocolíticas e sistêmicas) e os dados científicos interessantes que podem surgir do estudo destas quanto a virulência e evolução, o objetivo deste projeto foi avaliar a similaridade genética entre estes isolados e isolados de ST por diferentes técnicas moleculares como REP-PCR, Ribotipagem, tipagem com IS200 e 
perfil plasmidal. Como controle, foram adicionados isolados pertencentes as sorovariedades Enteritidis (SE) e Typhi (TY), também isoladas com frequiência na época do estudo. Os resultados indicam maior similaridade genética dos isolados Sti com ST, como esperado. Os isolados Sti foram separados em diferentes sub- grupos, indicando que podem derivar de clones distintos de ST. Um dado interessante foi verificar que estes isolados foram os de maior freqüência em infecções sistêmicas, sugerindo que as observações de Ikeda et al. (2001) com mutantes e no modelo murino podem também ser aplicadas para isolados humanos.

\section{ESTUDO DA LOCALIZAÇÃO DAS MIOSINAS VA e Vb EM TECIDOS DE GALINHA E RATO AO LONGO DO DESENVOLVIMENTO EMBRIONÁRIO E NO ADULTO}

\section{Cláudia Helena Pellizzon}

Orientadora: Profa. Dra. Enilza Maria Espreáfico

Tese de Doutorado apresentada em 29/11/2002

As três formas de miosinas da classe $\mathrm{V}, \mathrm{Va}, \mathrm{Vb}$ e Vc, descritas até o momento, em vertebrados, são motores moleculares envolvidos em uma série de funções essenciais, dentre elas, o transporte de vesículas pós-Golgi, compartimentos melanoendolisossômicos, retículo endoplasmático liso, mRNA, orientação do fuso mitótico e participação em via de transdução de sinal do cálcio. Contudo, durante o desenvolvimento embrionário de vertebrados, bem como em tecidos diferenciados do adulto, pouco se sabe sobre as funções específicas das miosinas da classe $\mathrm{V}$ e tampouco se conhece o padrão de expressão e distribuição tecidual dos diversos membros dessa classe. No presente trabalho, a expressão e distribuição tecidual das miosinas $\mathrm{Va}$ e $\mathrm{Vb}$ foram estudadas durante a embriogênese ini- cial em galinha e em tecidos de diversos orgãos especializados de ratos adultos. Para tanto, foram produzidos e caracterizados anticorpos monoespecíficos contra cauda terminal das miosinas $\mathrm{Va}$ e $\mathrm{Vb}$. A miosina Va mostrou-se mais abundante em lisado total embrionário nas etapas do desenvolvimento estudado (33, 72 e 120 horas). Imunomarcação em cortes histológicos revelou ampla distribuição dessas miosinas nos sistemas nervoso, digestivo, respiratório e urinário. Ambas ocorrem em todo o neuroepitélio, retina e epitélio dos túbulos renais com alguma diferença de intensidade de expressão. Em tecidos de animais adultos, mostramos que ambas as miosinas estão presentes na retina, tireóide, pâncreas, testículo, ovário, tuba uterina, traquéia, intestino delgado e rim. No entanto, na maioria dos tecidos, apresentam expressão diferencial, isto é, em tipos celulares específicos ou localização intracelular diferencial, o que sustenta a hipótese de que estas duas miosinas exerçam funções complementares e, de modo geral, não-redundantes no organismo.

\section{BIOQUÍMICA}

\section{ESTUDO BIOQUÍMICO E FUNCIONAL DE NEUTRÓFILOS HUMANOS DE PACIENTES COM DOENÇA DE GRAVES}

Elisa Maria de Sousa Russo Carbolante Orientadora: Profa. Dra. Yara Maria Lucisano Valim Tese de Doutorado apresentada em 12/07/2002

A doença de Graves (DG) é uma doença autoimune órgão específica da tireóide, caracterizada por hipertireoidismo, oftalmopatia e mixedema pré-tibial. Pacientes com esta doença têm uma reatividade imune, mediada tanto por células quanto por anticorpos contra os receptores de TSH, contra a tiroglobulina e contra a tireóide peroxidase. A reatividade imune inclui o desenvolvimento de anticorpos (Ac) a esses antígenos, reatividade dos linfócitos, desenvolvimento 
de imunocomplexos (IC) circulantes e depósitos de IC. Os Ac contra o receptor de TSH se ligam a esse receptor de uma maneira funcionalmente positiva levando à estimulação da tireóide e por conseqüência, à grande produção de hormônios.

Uma vez que esta patologia é de auto-imune, que há depósitos de IC e que uma das complicações importantes (oftalmopatia) é um processo auto-imune e inflamatório e, ainda, que os neutrófilos estão envolvidos na fisiopatologia destes dois processos, a proposição deste trabalho foi fazer um estudo bioquímico e funcional dos neutrófilos de pacientes com doença de Graves, em diferentes estágios da doença e do tratamento. Os estudos destas células envolveram: a) quantificação da produção de espécies reativas de oxigênio por quimioluminescência dependente de luminol ou lucigenina, mediadas por receptores para $\mathrm{IgG}$ bem como pela cooperação entre receptores do complemento e para IgG ; b) avaliação da expressão dos receptores para complemento (CR) e para IgG (FcyR); c) averiguação da presença de anticorpos ligados aos receptores dos neutrófilos de sangue periférico; d) medida da atividade da superóxido dismutase; e) medidas da produção de peróxido de hidrogênio pelos neutrófilos e f) medidas do conteudo de glutationa reduzida destas células.

Os resultados mostraram que a produção de radicais de oxigênio, mediada por CR e/ou FcyR, pelos neutrófilos de pacientes com DG, estava aumentada em relação à produção pelos neutrófilos de indivíduos saudáveis, quando estas células foram estimuladas por imunocomplexo (IC) opsonizados ou não. Este aumento poderia ser devido a fatores como o aumento de expressão de receptores de membrana ou alterações nos mecanismos envolvidos na produção ou eliminação destas espécies reativas de oxigênio.
A porcentagem de células que expressam receptores para complemento e para IgG e a média de fluorescência por célula encontrada nas células de pacientes e controles, analisadas por experimentos de citometria de fluxo, foi bastante similar. Esses resultados indicaram que o aumento do burst oxidativo, verificado nos experimentos de QL, não foi devido à expressão anormal dos receptores que medeiam este processo. Também foi demonstrado que não haviam imunoglobulinas previamente ligadas aos PMN, o que poderia causar a estimulação prévia dessas células, assim como uma ocultação dos receptores analisados.

Foi encontrado aumento da produção de peróxido de hidrogênio nos neutrófilos de pacientes de DG hipertireoideos em relação aos indivíduos controles saudáveis. E contrapartida, as defesas antioxidantes avaliadas (atividade da superóxido dismutase e conteúdo de glutationa reduzida) nos neutrófilos desses pacientes não estavam significativamente diferentes daquelas dos neutrófilos de indivíduos controles.

$\mathrm{O}$ conjuntos desses resultados nos indica que Os neutrófilos dos pacientes estudados apresentaram um estresse oxidativo, o que pode ser bastante prejudicial e contribuir para um maior dano tecidual, principalmente em situações onde exista um processo inflamatório. Este dano seria em conseqüência à liberação de potentes substâncias oxidantes que poderiam não estar sendo devidamente eliminadas pelos mecanismos antioxidantes dos neutrófilos. A produção alterada de radicais de oxigênio nestes neutrófilos pode estar relacionada com uma maior atividade da NADPH oxidase destas células.

Finalmente, sugerimos a introdução de terapia antioxidante aos pacientes de DG para que os efeitos tóxicos e deletérios dos neutrófilos, nos processos inflamatórios teciduais, sejam minimizados.

\section{ESTUDO DOS EFEITOS DA NIMESULIDA E DO SEU METABOLITO REDUZIDO EM MITOCÔNDRIAS E HEPATÓCITOS ISOLADOS DE RATO}

\section{Fábio Ermínio Mingatto}

Orientador: Prof. Dr. Carlos Curti

Tese de Doutorado apresentada em 12/07/2002

Nimesulida é um fármaco antiinflamatório não esteroidal (AINE) de amplo uso clínico devido à sua ação antiinflamatória, analgésica e antipirética, apesar de inúmeros relatos de hepatotoxicidade devidos ao mesmo terem sido relatados na literatura. No presen- te trabalho, foram realizados estudos em mitocôndrias e hepatócitos isolados de rato visando avaliar os possíveis mecanismos de toxicidade do fármaco envolvendo a mitocôndria, além de estabelecer uma relação estrutura/atividade por comparação com os efeitos do seu metabólito resultante da redução do grupo nitro ao amino.

Em mitocôndrias isoladas foi observado estímulo da respiração de estado 4 dissipação do potenci- 
al de membrana e oxidação do $\mathrm{NAD}(\mathrm{P}) \mathrm{H}$. As curvas concentração-efeito referentes a esses parâmetros foram similares, com tendência à saturação em concentrações do fármaco superiores a $10 \mu \mathrm{M}$. Alem disso, o inchamento das mitocôndrias em meio hiposmótico de acetato de potássio foi concentração-dependente, indicando que o fármaco é um desacoplador protonoforético.

Na mesma faixa de concentração nimesulida induziu efluxo de $\mathrm{Ca}^{2+}$ das mitocôndrias com inibição parcial por vermelho de rutênio, um inibidor do transporte de $\mathrm{Ca}^{2+}$ pelo uniporter; em presença do mesmo inibidor o fármaco induziu inchamento das mitocôndrias em meio isosmótico, uma resposta típica da transição de permeabilidade mitocondrial (TPM). O inibidor clássico da TPM, ciclosporina $\mathrm{A}$, não só inibiu o inchamento mitocondrial, como também o efluxo de $\mathrm{Ca}^{2+}$ em uma condição desfavorável ao inchamento. Além disso, ambos os processos foram inibidos em proporções semelhantes pelos moduladores da TPM $\mathrm{Mg}^{2+}$, ADP, ATP e e butil-hidroxi tolueno (BHT), enquanto que ditiotreitol (DTT) e n-etilmaleimida (NEM), embora tenham inibido o inchamento mitocondrial, apresentaram apenas um efeito parcial ou nulo sobre o efluxo de $\mathrm{Ca}^{2+}$, respectivamente. Esses resultados sugerem que TPM e efluxo de $\mathrm{Ca}^{2+}$ induzidos por nimesulida são eventos que resultam da dissipação do potencial de membrana e/ou oxidação dos $\mathrm{NAD}(\mathrm{P}) \mathrm{H}$, com a prioridade em relação ao tipo de resposta (TPM ou efluxo de $\mathrm{Ca}^{2+}$ ) dependendo simplesmente da hablidade da mitocôndria em prevenir o efluxo do cátion pelo reverso do uniporter. Inibição de síntese de ATP pela nimesulida, também foi observado.

O metabólito reduzido da nimesulida não apresentou quaisquer dos efeitos descritos para o fármaco, indicando que grupo nitro é determinante para manifestação dos mesmos. Além disso o metabólito apresentou atividade antioxidante, diminuindo o acúmulo de $\mathrm{H}_{2} \mathrm{O}_{2}$ gerada por $t$-butil hidroperóxido, e inibindo a lipoperoxidação da membrana mitocondrial mediada por $\mathrm{Fe}^{2+}$ /citrato.

Em hepatócitos isolados a nimesulida, mas não o seu metabólito reduzido, apresentou uma toxicidade concentração e tempo-dependente, demonstrada em ensaios de viabilidade celular por liberação da lactato desidrogenase $(\mathrm{LDH})$. A análise de alguns parâmetros bioquímicos de relevância toxicológica, tais como respiração e potencial de membrana das mitocôndrias, além dos níveis de ATP, glutationa reduzida $(\mathrm{GSH})$ e $\mathrm{NAD}(\mathrm{P}) \mathrm{H}$, demonstrou que o fármaco, mas não o seu metabólito reduzido, interfere tanto na energética das células quanto na defesa antioxidante, porém, sem provocar peroxidação dos lipídios de membrana . Estudos dos efeitos da nimesulida sobre a viabilidade celular em presença de frutose, oligomicina e ciclosporina A surgem que o fator energértico é particularmente relevante e que a TPM não está envolvida. Estudos em presença de proadifen, um inibidor do citocromo $\mathrm{P} 450$, o qual potencializou substancialmente o efeito da nimesulida sobre a viabilidade celular, sugere que o composto de origem é o principal responsável pela toxicidade observada nos hepatócitos isolados.

\section{CLÍNICA CIRÚRGICA}

\section{INFLUÊNCIA DO TABACO NA LESÃO DE ISQUEMIA/REPERFUSÃO EM RETALHOS CUTÂNEOS DE RATOS}

\section{Frederico Alonso Sabino de Freitas}

Orientador: Prof. Dr. Carlos Eli Piccinato

Dissertação de Mestrado apresentada em 02/08/2002

Múltiplos fatores têm sido implicados na patogênese da lesão de isquemia/reperfusão da pele, incluindo as espécies reativas de oxigênio (ERO). Por outro lado, sabe-se que a inalação crônica de tabaco resulta em depleção do sistema antioxidante endógeno e grau variável de vasoconstricção cutânea. Empregando-se o retalho epigástrico do rato como modelo de isquemia/reperfusão na pele objetivou-se avaliar a influência do tabaco inalado, na lesão de isquemia/ reperfusão cutânea, através da dosagem tissular de malonildialdeído (MDA), xantina oxidase (XO) e mieloperoxidase (MPO). Níveis tissulares elevados de 
MDA são indicadores de lesão de membranas celulares caracterizadas pela lipoperoxidação. A xantina oxidase é uma enzima relacionada à produção intracelular de ER0 e a atividade da MPO representa indiretamente o grau de infiltração neutrofilica tecidual. $\mathrm{O}$ estudo foi dividido em 2 fases. $\mathrm{Na} 1^{\text {a }}$ fase estudaramse 8 ratos. Foram confeccionados dois retalhos epigástricos em cada rato, sendo um retalho controle e o outro contralateral submetido à isquemia e reperfusão. Após período de 16 h de isquemia e 45 min de reperfusão, foram colhidas biópsias cutâneas nestes retalhos e simultaneamente nos retalhos controles, para dosagem tissular de MDA. Analisando-se os níveis de MDA cutâneos, observou-se tendência à elevação de MDA em retalhos isquêmicos. Após a reperfusão houve elevação significativa de MDA em relação aos controles. Utilizou-se na $2^{\text {a }}$ fase do experi- mento um equipamento de inalação passiva, desenvolvido na Faculdade de Medicina de Ribeirão Preto, em 2 grupos de ratos, sendo que 12 ratos inalaram tabaco durante 4 semanas no pré-operatório (GF) e outros 12 animais não o inalaram (GNF). Confeccionou-se um retalho epigástrico por animal e este foi submetido à $16 \mathrm{~h}$ de isquemia e $45 \mathrm{~min}$ de reperfusão. Após os períodos de isquemia e reperfusão foram colhidas biópsias cutâneas destes retalhos para análise tissular de MDA, XO e MPO. Houve aumento significativo de MDA nos retalhos de ratos do GF em relação aos do GNF, caracterizando-se maior taxa de lipoperoxidação no GF. As atividades tissulares da XO e da MPO elevaram-se significativamente no GF em relação ao GNF. Com base nesses resultados, conclui-se que o tabaco inalado provocou agravamento das lesões de isquemia reperfusão em retalhos cutâneos de ratos.

\section{AVALIAÇÃO DA ATIVIDADE ELÉTRICA ATRIAL EM PACIENTES VALVOPATAS MITRAIS OPERADOS COM CIRCULAÇÃO EXTRA-CORPÓREA}

\section{Cesar Augusto Ferreira}

Orientador: Prof.Dr.Walter V. de Andrade Vicente Dissertação de Mestrado apresentada em 09/08/2002

A via de abordagem da valva mitral é fator crítico para boa exposição e minimização dos riscos de lesão das estruturas circunjacentes. O uso do acesso subseptal lateral direito clássico pode oferecer exposição difícil, sendo utilizadas vias alternativas, cujos efeitos na atividade elétrica atrial e no resultado cirúrgico são contraditórios. Foi estabelecida metodologia padronizada de investigação, cujo fundamento é a avaliação da atividade elétrica atrial, através da detecção dos distúrbios do ritmo cardíaco por meio de eletrocardiograma convencional e da monitoração eletrocardiográfica contínua (sistema Holter), nos períodos pré e pós-operatórios. A função do nó sinusal e o tempo de condução interatrial, foram obtidos por meio de estimulação atrial programada, pelo método de Narula, através dos fios de eletrodo epicárdicos atriais, posicionados nos átrios direito e esquerdo. Esta avaliação foi realizada à luz do quadro clínico dos pacientes e da detecção das alterações estruturais decorrentes das sobrecargas hemodinâmicas predominantes, pelo Doppler-ecocardiograma.

Foram operados 10 pacientes adultos consecutivos portadores de valvopatia mitral. O ritmo cardía- co foi o ritmo sinusal normal em 7 pacientes, estando os demais em fibrilação atrial. Todos os pacientes em ritmo sinusal apresentavam ectopias supraventriculares, com episódios de taquicardia supraventricular em 57\%, "flutter" atrial em $10 \%$ e ritmo juncional em 10\%. Todos os pacientes apresentavam ectopias ventriculares, com baixa incidência em $70 \%$ deles, taquicardia ventricular não sustentada em $30 \%$. Os pacientes foram operados pelo mesmo cirurgião, com técnica cirúrgica, anestésica, de circulação extracorpórea e cardio-plégica semelhantes. Não houve mortalidade. No pós-operatório, houve $40 \%$ de novas arritmias supra-ventriculares (fibrilação atrial, ritmo juncional, ritmo atrial baixo e taquicardia supraventricular paroxística), não ocorrendo arritmias ventriculares. Os fios de eletrodo epicárdicos atriais foram utilizados como marcapasso em $40 \%$ dos pacientes. À avaliação da função do nó sinusal, não houve prejuízo pelo procedimento cirúrgico realizado. Todos os pacientes tiveram boa evolução, em classe funcional I (NYHA) dentro de 30 dias do estudo. Houve redução significativa do tamanho do átrio esquerdo mas não houve redução significativa da duração da onda "P" ao ECG. Houve redução quantitativamente significativa das ectopias supraventriculares, com reversão de FA para ritmo sinusal em 1 paciente e não houve redução quanti-tativamente significativa das 
ectopias ventriculares. O tempo de condução interatrial apresentou correlação significativa com o tamanho do átrio esquerdo medido no pré e pós-operatório. Não houve complicações relacionadas à colocação, utilização e retirada dos fios de eletrodo epicárdicos. Observou-se, também, aumento nas frequiências cardíacas mínimas e redução das freqüências cardíacas máximas nos pacientes operados, comparando-se o pré com o pós-operatório.

Portanto, esta abordagem metodológica, relacionada à avaliação da atividade elétrica atrial, mostrouse adequada para detectar os distúrbios do ritmo em pacientes portadores de valvopatia mitral, operados pela via subseptal clássica, permitindo, assim, futuras comparações com as outras vias de exposição valvar mitral.

\section{AVALIAÇÃO NEONATAL DA HIDRONEFROSE INTRAUTERINA}

\section{Carlos Augusto Fernandes Molina \\ Orientador: Prof. Dr. Silvio Tucci Júnior \\ Dissertação de Mestrado apresentada em 14/08/2002}

Avanços na resolução da ultra-sonografia, na década de 80, permitiram sua utilização na investigação fetal. A hidronefrose, vista na infância por sintomas como dor, massa abdominal palpável, infecção do trato urinário e hematúria, passou a ser observada como dilatação do trato urinário na vida intra-uterina, sendo a estenose da junção ureteropiélica o fator etiológico mais comum. A detecção precoce ocasionou mudanças em relação à conduta médica para a hidronefrose. Sinônimo de obstrução, a hidronefrose era tratada por correção cirúrgica. Com a avaliação funcional pósnatal, no entanto, passou-se a exigir a presença de redução na função renal para ser considerada a associação entre hidronefrose e obstrução. Assim, a intervenção cirúrgica não estaria indicada em todos os casos, sendo, em muitos, adotado o seguimento clínico. A grande dificuldade está em identificar qual paciente irá se beneficiar de uma ou outra conduta. No presente estudo realizamos análise retrospectiva dos casos de hidronefrose diagnosticada intra-útero, no período entre 1996 e 2001. Dentre 116 neonatos, 45 apresentaram estenose da junção ureteropiélica como fator etiológico. A análise conjunta desses últimos casos mostrou que, de 26 pacientes mantidos inicialmente sob conduta conservadora, somente 6 (23\%) evoluíram para aqueles com critérios indicativos de cirurgia, durante o seguimento ambulatorial. Concluímos que grande número de pacientes nessa faixa etária seriam beneficiados pela conduta conservadora, evoluindo sem prejuízos para a função renal, sendo a cirurgia indicada em casos selecionados. A metodologia utilizada nesse grupo de pacientes foi adequada para defini-los quanto à opção terapêutica, porém, exigiu vários exames. Faz-se necessário identificar, no futuro, metodologia mais simples que possa assegurar com eficiência qual dilatação do trato urinário diagnosticada, no período intra-uterino, traduzirá obstrução do fluxo urinário, reduzindo custos e acelerando o processo de seleção de pacientes candidatos ao tratamento cirúrgico.

\section{EFEITO DE TRÊS DOSES DIFERENTES DE ALFENTANIL NA HEMODINÂMICA, NA LIBERA- ÇÃO DE CORTISOL E DE CATECOLAMINAS PÓS INTUBAÇÃO TRAQUEAL EM CRIANÇAS}

\section{Eneida Maria Vieira}

Orientador: Prof. Dr. Luís Vicente Garcia

Dissertação de Mestrado apresentada em 02/09/2002

Introdução: As consequiências das alterações hemodinâmicas decorrentes da laringoscopia e da intubação traqueal podem ser desastrosas para os pacientes, sobretudo para os de maior risco, como os coronariopatas e os hipertensos. As alterações hemodinâmicas que ocorrem após intubação traqueal estão relacionadas ao aumento da concentração plasmática de noradrenalina. Algumas drogas, como o fentanil, em altas doses, podem abrir as alterações hemodinâmicas e a liberação de catecolaminas pós intubação traqueal. Apesar de eficiente, o fentanil em altas doses tem o inconveniente de acarretar depressão respiratória no período pós operatório. Dessa forma, o 
alfentanil, um narcótico de ação ultra-curta pode produzir o mesmo efeito sem acarretar depressão ventilatória. Em adultos, todos esses efeitos estão bem documentados. Em crianças, no entanto, não sabemos se a utilização de opióides na indução da anestesia possa trazer algum benefício no tocante à abolição da resposta pressórica e da liberação de catecolaminas.

Casuística e método: Participaram do estudo 30 crianças saudáveis e que foram submetidas a procedimentos cirúrgicos de pequeno e médio porte. A indução da anestesia foi padronizada e as crianças foram divididas em 3 grupos, de acordo com a dose de alfentanil que receberam: 10, 20 ou $30 \mu \mathrm{g} / \mathrm{kg}$. Os parametros hemodinâmicos foram avaliados em 3 momentos distintos, após a indução anestésica, antes da intubação traqueal e 1 minuto após a intubação traqueal. Antes da intubação traqueal e 1 minuto após a intubação traqueal colheu-se sangue para a quantificação do cortisol plasmático e das catecolaminas.

Resultados: O comportamento hemodinâmico após a intubação traqueal foi semelhante nos três grupos. A concentração plasmática de cortisol e de noradrenalina não se alterou após a intubação traqueal em relação aos valores obtidos imediatamente antes da intubação.

Conclusões: Não houve, em todos os parâmetros avaliados, diferença entre os três grupos, ou seja, a dose de 10 microgramas $/ \mathrm{Kg}$ já pode ser eficiente para abolir a resposta endócrino-metabólica à intubação traqueal.

\section{DESENVOLVIMENTO DE PROTÓTIPO DE DISPOSITIVO PARA MACROENCAPSULAMEN- TO DE ILHOTAS PANCREÁTICAS A PARTIR DE BIOMEMBRANA DE LÁTEX NATURAL}

\section{Ênio David Mente}

Orientador: Prof. Dr.Reginaldo Ceneviva

Tese de Doutorado apresentada em 28/10/2002

O transplante de ilhotas pancreáticas encapsuladas poderá tornar-se a principal modalidade terapêutica para os pacientes com diabetes mellitus tipo 1. Os principais problemas relacionados a este tipo de tratamento são a necessidade de uso de imunossupressores e a dificuldade de trocas entre as células implantadas e o hospedeiro. A descoberta de materiais biocompatíveis que induzam neoformação vascular e garantam imunoisolamento é essencial para melhoria nos resultados dos transplantes. Com este objetivo, testou-se uma nova biomembrana de látex natural para o desenvolvimento de um dispositivo para o transplante celular encapsulado.

Biomembranas de látex natural impermeáveis foram implantadas no subcutâneo de ratos normais e diabéticos. O material foi submetido a avaliação histológica e imunoistoquímica, com anti-CD34 e antiVEGF, 21, 60, 90 e 365 dias após o implante. Desenvolveu-se posteriormente uma membrana de látex semipermeável, submetida à mesma avaliação 21 dias após o implante em ratos normais. As superficies das biomembranas de látex foram analisadas por microscopia eletrônica de varredura. Foi construído um protótipo de dispositivo para macroencapsulamento celular com a membrana semipermeável, e testada sua permeabilidade, in vivo, a substâncias de diferentes pesos moleculares. Este dispositivo foi implantado no subcutâneo de ratos para avaliação da taxa de captação de glicose e aminoácidos através de microdiálise in vivo.

As membranas de látex não sofreram rejeição e foram envolvidas por tecido fibroso com intensa neoformação vascular. O número de vasos, cerca de 200 por centímetro de membrana, permanceu constante ao longo do tempo. Células endoteliais foram envidenciadas na região de interface tecido-membrana através de marcação com antiCD-34 e de microscopia eletrônica. Houve expressão do VEGF neste local. O dispositivo construído a partir da membrana microporosa foi impermeável ao azul de dextrana, mas permeável à albumina e a imunoglobulina. A taxa de captação de glicose e aminoácidos in vitro foi de cerca de $10 \%$, e houve difusão de aminoácidos para interior do dispositivo no estudo in vivo.

As biomembranas de látex natural são biocompatíveis e induzem neoformação vascular duradoura. O dispositivo construído com membrana de látex semipermeável permite a difusão de glicose, aminoácidos e albumina, nutrientes importantes para a sobrevida das células encapsuladas. A não difusão de azul de dextrana (2000 kDa) é um indício de que a membrana impede a penetração de células do sistema imune. Essas características sugerem que o dispositivo apresenta potencial para ser utilizado como suporte para o implante de células isoladas. 


\section{AVALIAÇÃO CLÍNICA E URODINÂMICA DA INCONTINÊNCIA URINÁRIA EM PACIENTES SUB- METIDOS À PROSTATECTOMIA RADICAL RETROPÚBICA}

\section{Rodolfo Borges dos Reis}

Orientador: Prof. Dr.Antonio Carlos Pereira Martins

Tese de Doutorado apresentada em 08/11/2002

A incidência da incontinência urinária pós prostatectomia radical varia de 2 a $87 \%$. Muitos investigadores relataram a presença de deficiência esfincteriana, associada ou não à disfunção vesical, como sendo a principal causa das perdas urinárias. A inexistência de uma classificação baseada em achados urodinâmicos e clínicos que facilite a identificação do tipo de população estudada, à falta de padronização de leak point pressure (LPP) abdominal, usado para avaliar a função esfincteriana pós prostatectomia radical, aliado à falta de correlação entre a intensidade das perdas urinárias mensurada através de informações clínicas fornecida pelos pacientes e os valores do LPP-abdominal, motivaram a realização deste estudo. Foram estudados 68 pacientes submetidos à prostatectomia radical e com queixas de incontinência urinária há pelo menos 1 ano. Os grupos controles constituíram-se de 18 voluntários continentes que não foram submetidos a cirurgia prostática (grupo 1) e 23 voluntários que referiram estar continentes após a prostatectomia radical retropública (grupo 2). Os indivíduos recrutados responderam a 22 questões do questionário para sintomas do trato urinário inferior da So- ciedade Internacional de Incontinência Urinária e foram submetidos à avaliação vídeo-urodinâmica. Os pacientes com queixas de incontinência urinária também foram submetidos ao teste do absorvente de 24 horas, visando quantificar objetivamente as perdas urinárias. Após a realização da avaliação urodinâmica, que inclui o LPP-abdominal padronizado por nós, os pacientes incontinentes foram divididos em 3 grupos, de acordo com a causa da incontinência urinária: 32 pacientes apresentavam incontinência urinária pós prostatectomia radical retropública causada por deficiência esfincteriana pura (grupo 3); 30 pacientes apresentavam incontinência urinária pós prostatectomia radical retropública causada por deficiência esfincteriana associada a componente vesical (grupo 4); 6 pacientes apresentavam incontinência urinária pós prostatectomia radical retropública causada por disfunção vesical (grupo 5). Não foi observada correlação entre os valores do LPP-abdominal e do teste do absorvente de 24 horas nos pacientes do grupo 4 . Os pacientes do grupo 3 apresentaram correlação inversa entre os valores do LPP-abdominal e o teste do absorvente de 24 horas. Nossos achados propiciaram a elaboração de uma classificação para pacientes incontinentes pós prostatectomia radical baseada no fator etiológico, diagnosticado pelo teste urodinâmico, e na intensidade das perdas avaliadas pelo LPP-abdominal.

\section{O PAPEL DA ARTÉRIA HEPÁTICA NA LESÃO POR ISQUEMIA E REPERFUSÃO DO FÍGADO CANINO: ESTUDO IN VITRO DO RELAXAMENTO ARTERIAL DEPENDENTE DE ÓXIDO NÍTRICO}

\section{Luiz Eduardo Correia Miranda}

Orientador: Prof. Dr. Reginaldo Ceneviva

Tese de Doutorado apresentada em 25/11/2002

O endotélio vascular sintetiza várias substâncias vasoativas, entre elas o óxido nítrico. A constatação de que o endotélio é mais susceptível à lesão por isquemia e reperfusão do que outros tecidos levou a sugestão de que a lesão endotelial contribuiria para as consequiências observadas no tecido reperfundido. No fígado, o desbalanço entre a ação de endotelinas e óxido nítrico tem sido responsabilizado pelos danos observados a microcirculação hepática. Pouca atenção tem sido dispensada às conseqüências da lesão do endotélio da artéria hepática na lesão por isquemia e reperfusão deste órgão. Objetivo: avaliação in vitro da função endotelial da artéria hepática canina, comparando-a de maneira tempo-dependente ao aparecimento da lesão hepática. Métodos: 24 cães de ambos os gêneros foram divididos nos seguintes grupos: Controle, cães operados sem sofrer isquemia ou reperfusão hepática; $I_{60}$, cães submetidos a 60 minutos de isquemia da artéria hepática e do fígado; $\mathrm{I}_{30} / \mathrm{R}_{60}$, cães submetidos a 30 minutos de isquemia e 60 minutos de reperfusão e $\mathrm{I}_{45} / \mathrm{R}_{120}$, cães submetidos a 45 minutos de isquemia e 120 de reperfusão da artéria hepática e do fígado. A artéria hepática foi estudada em câma- 
ras de banho orgânico, obtendo-se curvas dose-respostas para acetilcolina, $\mathrm{A}_{23187}$, fosfolipase-C, Naf, poli-L-arginina, nitroprussiato de sódio e isoproterenol. Amostras de fígado foram obtidas para dosagem de malonildialdeído (MDA), para estudo da respiração mitocondrial por meio de traços polarográficos e para avaliação do potencial de membrana mitocondrial. Sangue foi obtido para dosagem de transaminases e DHL. Resultados: não houve diferenças entre os grupos para o relaxamento arterial pbservado para todas as drogas testadas. $\mathrm{O}$ grupo $\mathrm{L}_{45} / \mathrm{R}_{120}$ apresentou evidente aumento dos valores de transaminases e DHL, aumento dos valores de MDA e tendência à diminuição da respiração mitocondrial estimulada por ADP, sem haver prejuízo irreversível para a fosforilação oxidativa ou para o potencial de membrana mitocondrial. Conclusão: o conjunto dessas observações demonstra que no território hepático a lesão hepatocelular do fígado pode ser documentada mais precocemente do que a lesão do endotélio da artéria principal que irriga o órgão. Esse resultado permite que o óxido nítrico derivado do endotélio da artéria hepática não contribui para as fases iniciais da lesão por isquemia e reperfusão do fígado canino.

\section{AVALIAÇÃO DO GASTO ENERGÉTICO OBTIDO PELA CALORIMETRIA INDIRETA E PELA EQUAÇẪO DE HARRIS-BENEDICT NO PACIENTE EM ESTADO GRAVE}

\section{Francisco Antonio Coletto}

Orientador: Prof. Dr. Anibal Basile Filho

Dissertação de Mestrado apresentada em 03/12/2002

A determinação precisa das necessidades energéticas está incluída na primeira fase dos cuidados ao paciente em estado grave, a fim de se evitar condições prejudiciais, como hipo ou hiperalimentação. Muitos estudos demonstram grandes diferenças entre o gasto energético medido por calorimetria indireta e os valores obtidos através de equações presuntivas, dentre elas a equação de Harris-Benedict.

O objetivo deste estudo foi avaliar a utilização das equações de Harris-Benedict, os fatores de correção específicos para injúria (sepse) e o uso da calorimetria indireta, em pacientes graves vítimas de sepse e/ou trauma de qualquer origem.

Foram estudados 28 pacientes com critérios para sepse (15 homens e 13 mulheres), com idade de 46,6 $\pm 19,5$ anos. O índice prognóstico APACHE II foi de $23,7 \pm 7,8$ e o risco de óbito calculado pelo APACHE II de 48,5 $\pm 27,5 \mathrm{O}$ sistema de graduação de sepse (SS) foi de $22 \pm 7,7$ Todos os pacientes estavam sob ventilação mecânica e sedação.

Um total de 85 medidas de calorimetria indireta foi realizado nos 28 pacientes, que foram divididos em dois grupos (I - com quatro séries de medidas de calorimetria indireta durante 30 minutos e II - uma medida com período de 30 a 60 minutos). Os valores médios de gasto energético obtido pela calorimetria indireta (GER) para os 19 pacientes do grupo I, nos tempos $T_{1}$ a $\mathrm{T}_{4}$, foram de $\left.1625 \mathrm{kcal}^{-1} \mathrm{~d}^{-1} \mathrm{~T}_{1}\right), 1660 \mathrm{kcal} . \mathrm{d}^{-1}\left(\mathrm{~T}_{2}\right)$, $1685 \mathrm{kcal}^{\mathrm{d}} \mathrm{d}^{-1}\left(\mathrm{~T}_{3}\right)$ e $1705 \mathrm{kcal}^{-\mathrm{d}^{-1}}\left(\mathrm{~T}_{4}\right)$. Para os 09 pacientes do grupo II, com apenas única medida $\left(\mathrm{T}_{1}\right)$, de
$1351 \mathrm{kcal} . \mathrm{d}^{-1}$. O valor médio do gasto energético basal $\left(\mathrm{GEB}_{\mathrm{H}-\mathrm{B}}\right)$ foi de $1507,5 \pm 208,1 \mathrm{kcal} .{ }^{\mathrm{d}-1}$ para os pacientes do grupo I e $1317,1 \pm 240,7 \mathrm{~d}^{-1}$ para os grupos II; valores obtidos através da equação de Harris-Benedict. Quando utilizados os fatores de correção para injúria e atividade ( $\mathrm{GET}_{\mathrm{CALC}}$ )' os valores do gasto energético total calculado aumentaram em ambos os grupos $\left(2894,5 \pm 399,6 \mathrm{kcal} . \mathrm{d}^{-1} \mathrm{e} 2528,8 \pm 462,1 \mathrm{kcal} . \mathrm{d}^{-1}\right.$, para o grupo I e para o grupo II, respectivamente.

O valor médio do gasto energético real (GER) obtido através da calorimetria indireta é de 1669,0 \pm 266,0 kcal. $\mathrm{d}^{-1}$ para o grupo I e de 1351,2 $\pm 275,3 \mathrm{kcal}$. $\mathrm{d}^{-1}$ para o grupo II.

Em média, o gasto energético resultante da equação de Harris-Benedict $\left(\mathrm{GEB}_{\mathrm{H}-\mathrm{B}}=1507,5 \pm 208,1\right.$ kcal. $\left.\mathrm{d}^{-1}\right)$ é estatisticamente diferente $(\mathrm{p}=0,02)$ dos valores obtidos pela calorimetria indireta $(\mathrm{GER}=$ $\left.1669,0 \pm 266,0 \mathrm{kcal}^{-1} \mathrm{~d}^{-1}\right)$ no grupo I. N o grupo II, a diferença estatística entre o GEB $_{\mathrm{H}-\mathrm{B}}(1317,10 \pm 240,70$ kcal.d $\left.\mathrm{d}^{-1}\right)$ e o GER $\left(1351,22 \pm 275,34 \mathrm{kcal}^{\mathrm{d}} \mathrm{d}^{-1}\right)$ não foi observada $(p=0,41)$. No entanto, quando aplicados os fatores específicos de correção propostos por Long et al. em 1979, há diferenças estatísticas em todos os grupos.

Para toda a casuística, houve uma variação global de $8,2 \%$ entre o GER e o $\mathrm{GEB}_{\mathrm{H}-\mathrm{B}}$, $\operatorname{com} \mathrm{p}=0,007$. Nossos dados demonstram diferenças estatísticas entre o gasto energético medido através da calorimetria indireta e o basal calculado pela equação de HarrisBenedict. Entretanto, essa diferença pode ser questionada quanto à importância clínica. No entanto, os valores obtidos quando a equação é corrigida pelos fatores de injúria, superestima o gasto energético em mais que $50 \%$. 
Em conclusão, estes resultados sugerem que a equação de Harris-Benedict sem os fatores de correção parece ser mais apropriada em estimar o gasto energético nos pacientes em estado grave do que a equação corrigida. Além disso, o uso rotineiro da calorimetria indireta para guiar a suplementação calórica nos pacientes sépticos parece ser a técnica mais adequada na estimativa do gasto energético real neste grupo de pacientes. Nós sugerimos que, sempre quando possível ou necessário, o gasto energético deve ser medido e que a utilização das fórmulas presuntivas seja reavaliada a cada caso.

\section{RASTREAMENTO DO ADENOCARCINOMA PROSTÁTICO EM VOLUNTÁRIOS DE UMA RE- GIÃO DA BAHIA}

\section{Edson Luiz Paschoalin}

Orientador: Prof. Dr. Antonio Carlos Pereira Martins

Tese de Doutorado apresentada em 03/12/2002

Objetivos-Determinar a prevalência do adenocarcinoma prostático em uma amostra de voluntários entre 40 e 79 anos de idade de uma região nordestina e sua relação com o fenótipo antropológico. Verificar, ainda, a variação do PSA segundo a cor da pele e se seu valor para o diagnóstico do câncer pode ser melhorado pelo uso de critérios associados como a densidade do PSA e a relação PSA livre/PSA total.

Material e Métodos - O rastreamento para adenocarcinoma prostático foi realizado no município de Ipirá, Bahia, no segundo semestre de 2000, onde foram examinados inicialmente 499 voluntários com idade entre 40 e 79 anos. As biópsias prostáticas guiadas por ultra-som trans-retal (10 fragmentos) foram indicadas em voluntários com PSA > 2ng/ml (DPCImmulite) e/ou toque retal alterado. Os voluntários foram classificados em brancos, pardos e negros segundo o fenótipo antropológico associado à pergunta da existência de pais ou avós de cor distinta. Em 120 voluntários, sendo 40 sem câncer escolhidos ao acaso de cada subgrupo antropológico e em todos os portadores de câncer, associou-se a análise da origem racial pela análise genética de 5 VNTRs: APOB, F13A1, PAH, D4S43 e vW-I. As dosagens do PSA, o exame histológico das biópsias e o estudo dos VNTRs foram efetuados no HCFMRP-USP. Foram excluídos 26/147 voluntários com biópsias indicadas e que não compareceram para o procedimento.

Resultados - A prevalência do adenocarcinoma prostático na amostra estudada foi de $27 / 473(5,7 \%)$. Na faixa de 50-79 anos a prevalência foi de 27/341 $(7,9 \%)$. As proporções de câncer nos voluntários brancos, pardos e negros de 40 a 79 anos foram: brancos$1 / 148(0,6 \%)$, pardos- $6 / 90(6,7 \%)$ e negros- $20 / 235$
$8,5 \%)(\mathrm{p}=0,006)$. A prevalência entre brancos $(1 / 148)$ e não brancos (26/325) também mostrou diferente significante $(\mathrm{p}=0,0009)$. Observou-se através da análise dos VNTRs que a miscigenação dos indivíduos classificados como brancos, pardos e negros mostrou as seguintes proprorções respectivas de alelos caucasianos, africanos e ameríndios: $67,5 \pm 8 \%, 20,8 \pm 8 \%$ e $11,7 \pm 7 \% ; 54,8 \pm 9 \%, 36,3 \pm 5 \%$ e $8,9 \pm 7 \%$; e $45,3 \pm 3 \%$, $45,9 \pm 4 \%$ e $8,8 \pm 4 \%$. Nos portadores de câncer as proporções respectivas desses alelos foram $50,5 \pm 9 \%$, $49 \pm 8 \%$ e $0,5 \pm 4 \%$, e naqueles sem câncer foram $59,1 \pm 7 \%, 31,7 \pm 8 \%$ e $9,2 \pm 5 \%$. As medianas respectivas do PSA total em, brancos, pardos e negros não portadores de câncer não mostraram diferença quando comparadas no conjunto ( $\mathrm{p}=0,73)$ ou quando cotejadas por faixa etária. Entretanto, notou-se maior dispersão de valores em negros acima de 60 anos. Considerando-se os voluntários com PSAT entre 0 e 10ng/ $\mathrm{ml}$ a sensibilidade e especificidade do teste para detecção do câncer foram de $100 \%$ e $31,6 \%$ para o corte de $2,5 \mathrm{ng} / \mathrm{ml}$, e de $69,2 \%$ e $57,7 \%$ para o corte de $4 \mathrm{ng} / \mathrm{ml}$. Na faixa do PSAT entre 2,5 e $10 \mathrm{ng} / \mathrm{ml}$ a adoção do critério de corte do PSAL/PSAT em $20 \%$ elevaria a acurácia do teste de 31,0 para 51,4 , sendo que este mesmo nível de corte na faixa entre 4 e $10 \mathrm{ng} / \mathrm{ml}$ causaria elevação da acurária de 59,2 para, 62,1 sem perda da sensibilidade. Usando-se o corte do PSAD em 0,08 na faixa do PSAT entre 2,5 e 10ng/ml aumentaria a acurácia para 42,7, e o corte de 0,10 na faixa de PSAT entre 4 e $10 \mathrm{ng} / \mathrm{ml}$ a elevaria para 66,9, também sem perda da sensibilidade.

Conclusões - A prevalência do adenocarcinoma prostático em Ipirá foi de 5,7\%. A prevalência do tumor foi significativamente maior em não brancos que em brancos. O PSAT em voluntários sem câncer não variou de modo significativo nos diversos grupos antropológicos. Tanto a fração PSAL/PSAT quanto a PSAD podem melhorar a acurária do teste do PSAT sem afetar a sensibilidade. 


\section{CLÍNICA MÉDICA}

\section{INFUSÃO DE AMINOÁCIDOS E GLICOSE NO TRANSOPERATÓRIO}

Ernann Tenório de Albuquerque Filho

Orientador: Prof. Dr. Julio Sergio Marchini

Dissertação de Mestrado apresentada em 08/07/2002

Deficiências nutricionais são freqüentemente associadas a aumento das taxas de morbidade e mortalidade no pós-operatório. Descreve-se há mais de 50 anos a relação existente entre perda de peso corporal pré-operatório e o aumento da mortalidade no pós-operatório. Vários fatores, além da desnutrição em si, contribuem para este quadro, entre eles a própria doença de base, a cirurgia, infecções associadas, dentre outros.

Sabidamente, na presença de trauma físico e ou metabólico, são observadas alterações no metabolismo das proteínas e dos aminoácidos, além da liberação e aumento de hormônios catabolizantes.

$O$ presente trabalho objetiva avaliar se a infusão endovenosa de aminoácidos e glicose, em via periférica, em pacientes submetidos ao estresse cirúrgico, altera esse estresse e/ou resulta em retenção de nitrogênio aminoacídico. Foram estudados 18 pacientes, triados e operados pela mesma equipe médica captados do ambulatório do Serviço de Cirurgia Geral do Hospital Universitário da Universidade Federal de Alagoas.

Após serem avaliados e, consentida a realização do protocolo de estudo, foram submetidos à ava- liação nutricional e, aleatoriamente, divididos em dois grupos. O grupo I, ou controle, durante o período transoperatório, recebeu solução de ringer com lactato e glicose 5\%, como rotineiramente utilizado pelo Serviço de Anestesia e Cirurgia da Universidade Federal de Alagoas. O grupo II, ou teste, além da infusão de soro ringer com lactato e glicose $5 \%$, recebeu aminoácidos $6,6 \%$ e glicose $16,6 \%$, equivalente, respectivamente, a 50 gramas de proteína e $250 \mathrm{~g}$ de glicose.

Observou-se, nos resultados, que não houve diferença estatística entre os grupos estudados, no que se refere à sexo, faixa etária, exames bioquímicos, aminoácidos e concentração urinária de adrenalina no pré e pós-operatório. Observou-se, ainda, que o grupo II, que recebeu solução de aminoácidos e glicose, não excretou mais nitrogênio nos períodos pré, trans e pósoperatório, em comparação ao grupo I, mantendo os valores semelhantes ao grupo I após 24 horas do início da anestesia. No entanto, o grupo II, embora tenha excretado quantidades semelhantes de nitrogênio em comparação ao grupo I, teve um balanço nitrogenado, em média, menos negativo que o grupo I $(\mathrm{p}<0,05)$, retendo aproximadamente $40 \%$ a mais de nitrogênio aminoacídico.

Conclui-se, desta forma, que a infusão parenteral de nitrogênio aminoacídico 6,6\% e glicose $16,6 \%$ no transoperatório pode ser benéfico aos pacientes sob estresse cirúrgico.

\section{AVALIAÇÃO DAS ALTERAÇÕES DA TROMBOPOETINA (TPO) SÉRICA, DAS PLAQUETAS E DAS CÉLULAS PROGENITORAS HEMATOPOÉTICAS NO SANGUE PERIFÉRICO DE DOA- DORES SAUDÁVEIS SUBMETIDOS A PLAQUETAFÉRESE}

\section{Benedito de Pina Almeida Prado}

Orientador: Prof. Dr. Dimas Tadeu Covas

Dissertação de Mestrado apresentada em 16/07/2002

Histórico: A trombopoetina (Tpo) é o principal fator de crescimento da linhagem megacariocitária (MK), sendo que seus níveis são regulados pela massa megacariocitária e plaquetária. Apresenta efeitos biológicos específicos na linhagem MK e inespecíficos nas células progenitoras hematopoéticas mais primitivas. Adicionalmente, a plaquetaférese induz a depleção plaquetária e pode provocar ativação plaquetária.

Objetivos: Avaliar efeitos da plaquetaférese sobre a concentração sérica de Tpo, a cinética de recuperação plaquetária, a ativação plaquetária, a liberação de plaquetas reticuladas, a liberação de reticulócitos, contagem de células CD34+e de células progenitoras hematopoéticas em circulação capazes de induzir a formação de colônias hematopoéticas in vitro. 
Material e Métodos: Vinte e cinco doadores de plaquetas, do sexo masculino, saudáveis, foram submetidos a plaquetaférese em equipamento Excel de fluxo contínuo. Amostras de sangue periférico foram coletadas pré-procedimento, imediatamente após (pósimediato), $2 \mathrm{~h}$ após e nos dias $+1,+2,+3,+4,+5,+7$ e +9 após o procedimento. Nessas amostras, realizamos contagens celulares em contador hematológico automático e, por citometria de fluxo, foram avaliadas a concentração de plaquetas ativadas, plaquetas reticuladas, reticulócitos e células CD34+ (exceto na amostra pós-imediato). Nas amostras pré e dos dias $+1,+4,+7$ e +9 foram realizados ensaios clonogênicos e culturas de megacariócitos. Nas amostras pré, $2 \mathrm{~h}$ após e dos dias $+1 \mathrm{a}+4$ realizamos quantificação da Tpo por técnica imunoenzimática (Elisa).

Resultados: Cinética plaquetária: contagens de plaquetas com queda acentuada no pós-imediato (média de redução $29,79 \pm 9,4 \% ; p<0.0001$ ), com retorno aos níveis pré-aférese no dia +7 . Ensaio clonogênico: precursores hematopoéticos BFU-E apresentaram-se elevados em relação aos níveis pré-aférese nos dia +4 e $+7(\mathrm{p}<0.001)$, precursores CFU-GM apresentaram-se elevados no dia $+7(\mathrm{p}<0.05)$. Cultura de megacariócitos: precursores CFU-MK aumentaram em relação aos níveis pré-aférese nos dias $+4(\mathrm{p}<0.05)$, $+7(\mathrm{p}<0.05)$ e $+9(\mathrm{p}<0.01)$.

Não foram encontradas alterações significantes da Tpo sérica, da ativação plaquetária, das plaquetas reticuladas e dos reticulócitos ( $\mathrm{p}>0.05)$.

Conclusões: As plaquetas retornaram aos níveis basais pré-aférese no dia +7 . Não ocorreram alterações estatísticamente significantes das contagens de plaquetas ativadas, das plaquetas reticuladas e dos níveis da Tpo sérica. Apesar disso, foram abundantes as alterações potencialmente atribuíveis à Tpo, com a mobilização de células progenitoras comissionadas e o recrutamento de células CD34+, provavelmente resultantes do incremento de atividade proliferativa hematopoética.

\section{MUTAÇÃO LIBANSESA: VARIAÇÕES DE APRESENTAÇÕES CLÍNICAS E POLIMORFISMOS}

\section{Denise Elena Franchi Benetti}

Orientador: Prof. Dr. José Ernesto dos Santos

Dissertação de Mestrado apresentada em 03/08/2002

A hipercolesterolemia familiar é uma doença que se caracteriza pela elevação da concentração plasmática de LDL-colesterol, associada ao aparecimento de xantomas e obstrução coronariana em idade jovem, levando a doença cardíaca isquêmica que geralmente constitui a causa da morte.

A doença é causada por defeitos na síntese, no transporte intracelular, na capacidade de ligação ou na reciclagem do receptor da apoB da LDL (LDL-r).

A mutação libanesa (substituição C/A no códon 660, no exon 14 do gene LDL-r) afeta 1 em 500 indivíduos e e é causada por defeito na síntese do LDL-r, sendo causa freqüente de hipercolesterolemia familiar no Brasil.

Foram estudados 32 indivíduos, distribuídos posteriormente em dois grupos: portadores da Mutação Libanesa (G1) e não portadores da mutação libanesa (G2). A média de idades foi de $51 \pm 15$ anos no grupo G1 e 56,9 \pm 13 anos no grupo G2. A média dos níveis séricos de CT foi de $377,7 \pm 61,7 \mathrm{mg} / \mathrm{dl}$ para o grupo 1 e 305,9 $\pm 33,3 \mathrm{mg} / \mathrm{dl}$ para os indivíduos do grupo $\mathrm{G} 2$, sendo que o teste " $t$ " para amostras independentes mostrou diferença significativa entre os dois grupos de indivíduos com $p=0,001$. A média entre os níveis séricos de LDL-c para os grupos G1 e G2 foram respectivamente de $289,7 \pm 61 \mathrm{mg} / \mathrm{dl} \mathrm{e} 224,3 \pm 30 \mathrm{mg} / \mathrm{dl}$, com valor de $\mathrm{p}=0,002$.

Foi avaliada a resposta terapêutica à atorvastatina cálcica nos dois grupos estudados. Os indivíduos não portadores do alelo libanês, após ingestão de 10 $\mathrm{mg}$ de atorvastatina cálcica, pelo período de 30 dias consecutivos, tiveram redução dos níveis séricos de CT de 122,9 $\pm 41,2 \mathrm{mg} / \mathrm{dl}$ com valor de $\mathrm{p}$ ajustado de Bonferroni $<0,001$. A diferença das médias para 0 LDL-c foi $=119,7 \pm 40,1 \mathrm{mg} / \mathrm{dl}$ com $\mathrm{p}$ ajustado de Bonferroni $<0,001$.

Os indivíduos portadores da Mutação Libanesa, utilizaram atorvastatina cálcica, nas doses de 10 $\mathrm{mg}, 20 \mathrm{mg}$ e $30 \mathrm{mg}$. Para a dose de $10 \mathrm{mg}$ da respectiva droga, a diferença entre as médias para os níveis séricos do CT foi 99,2 $\pm 36,4 \mathrm{mg} / \mathrm{dl}$ com valor de $\mathrm{p}$ ajustado de Bonferroni< 0,001. A diferença entre as médias dos níveis séricos de LDL-c foi de 78,9 \pm 35 $\mathrm{mg} / \mathrm{dl}$. O valor de $\mathrm{p}$ ajustado de Bonferroni $<0,001$. Portanto, houve redução estatisticamente significativa, tanto nos níveis séricos do CT como nos níveis séricos do LDL-c. Para a dose de $20 \mathrm{mg}$ de atorvastatina cálcica, a diferença entre as médias dos níveis séricos do CT foi de 137,7 $\pm 58,1 \mathrm{mg} / \mathrm{dl} \mathrm{p}<0,001$, 
mostrando que houve uma redução estatisticamente significativa do CT. A diferença entre as médias de LDL-c foi de 165,3 $\pm 58,5 \mathrm{mg} / \mathrm{dl}$ com $\mathrm{p}<0,006$. Com o uso de $30 \mathrm{mg}$, a diferença entre as médias dos níveis séricos do CT foi 178,8 \pm 57,9 mg/dl, com $\mathrm{p}=0,004$, mostrando que houve uma redução significativa nos níveis séricos do CT. A diferença para as médias dos níveis séricos do LDL-c quando se administrou $30 \mathrm{mg}$ da droga foi de $165,3 \pm 58,5 \mathrm{mg} / \mathrm{dl}$. O valor de $\mathrm{p}$ ajustado de Bonferroni $=0,006$ mostrando redução estatisticamente significativa nos níveis do LDL-c.

Os indivíduos hipercolesterolêmicos portadores do alelo libanês, apresentaram índices significativamente maiores para a doença aterosclerótica coronariana em suas diversas formas e manifestações clínicas quando comparados com os indivíduos hipercolesterolêmicos não portadores do alelo libanês. Foram encontrados $52,9 \%$ x 6,7\% de individuos com IAM nos grupos $\mathrm{G} 1$ e $\mathrm{G} 2$ respectivamente, sendo que o Teste Exato de Fisher mostrou diferença estatisticamente significativa entre os dois grupos com $p=0,007$. Entre os indivíduos do grupo G1 encontramos 47,6\% de revascularização miocárdica, não sendo encontrado nenhum indivíduo com tratamento cirúrgico para DAC no grupo $\mathrm{G} 2(\mathrm{p}=0,002)$.

Encontramos um percentual maior de episódios de Angina Pectoris em portadores do alelo libanês, com $47,1 \%$ de casos x 13,3\% em hipercolesterolêmicos não portadores do alelo para a mutação libanesa. O Teste Exato de Fisher mostrou diferença significativa entre os dois grupos com $\mathrm{p}=0,006$.

Todos os indivóduos portadores do alelo para mutação libanesa apresentaram história familiar positiva para DAC (100\%). Entre os hipercolesterolêmicos não portadores de mutação libanesa, o percentual para história familiar de DAC foi positivo em apenas 33\%.

Foram estudados, em hipercolesterolemia, alguns polimorfismos genéticos nos genes da apoB e apoE, e defeitos do gene do LDL-r, correlacionando os diferentes genótipos com as diversas formas clínicas da apresentação da doença arterial coronariana, representada em maior grau pela miocardiopatia isquêmica.
O critério utilizado para diagnosticar a hipercolesterolemia familiar foi firmado pelos seguintes índices: colesterol sérico total (CT) e colesterol ligado do LDL (LDL-c) acima do percentil 95\% para idade e sexo, níveis plasmáticos de triglicérides (TGL) abaixo de $400 \mathrm{mg} \%$ e presença de outros parentes de primeiro grau com a mesma doença.

A presença de doença isquêmica do coração foi avaliada através do ecocardiograma bidimensional com doppler, ecocardiograma de estresse farmacológico e pela cintilografia de perfusão miocárdica, todos esses exames segundo protocolo fixado pela Faculdade de Medicina de Ribeirão Preto da Universidade de São Paulo/USP.

A presença de doença aterosclerótica das artérias carótidas, foi também avaliada por eco-doppler, relacionando a espessura das suas camadas íntima e média com o risco para doença arterial coronariana.

Laboriatorialmente foram pesquisados: presença da mutação libanesa, polimorfismos da apoB (Xbal, EcoRI e 3'VNTR), polimorfismos da apoE e os níveis séricos de lípides. Polimorfismos envolvidos em outros processos ligados a aterogênese como os polimorfismos da paraoxonase e os da metilenetetrahidrofolatoredutase (MTHF-R) foram determinados por reação em cadeia da polimerase (PCR).

Não houve diferenças significativas entre os grupos G1 e G2 nas frequiências alélicas dos locos da apoB: Xbal e EcoRI. O teste do Qui-Quadrado revelou $\mathrm{p}=0,47$ e $\mathrm{p}=0,60$ respectivamente.

Para os outros genes envolvidos na aterogênese como a paraoxonase, o teste do Qui-Quadrado não revelou diferença estatística significativa entre os dois grupos, com $\mathrm{p}=0,91$. Para a MTHF-R encontramos as seguintes freqüências genotípicas: AA $(11,8 \%)$, VV $(29,4 \%)$ e AV $(58,8 \%)$ em portadores do alelo libanês e AA (40\%), VV (13,3\%) e AV (46,7\%) nos indivíduos do grupo G2.

Nos indivíduos do grupo G1 encontramos $100 \%$ de homozigose para a isoforma E3 da apoE, sendo que no grupo $\mathrm{G} 2$ encontramos os seguintes genótipos: E3/E3 (60\%), E3/E4 (27\%), E2/E3 (6,75) e E4/E4 $(6,7 \%)$.

\section{ESTUDO SOROEPIDEMIOLÓGICO DO VÍRUS DA HEPATITE B E HEPATITE C EM PORTADO- RES DO VÍRUS DA IMUNODEFICIÊNCIA HUMANA/SIDA NA CIDADE DE BELÉM, PARÁ-BRASIL}

\section{Maria Rita de Cassia Costa Monteiro}

Orientador: Prof. Dr. José Fernando de C. Figueiredo

Tese de Doutorado apresentada em 09/08/2002
Esta investigação foi realizada no período de setembro de 1999 a abril de 2000 , com o objetivo de estudar a prevalência dos marcadores de infecção pelos 
vírus da hepatite $\mathrm{B}$ e hepatite $\mathrm{C}$ em portadores do vírus da imunodeficiência humana, maiores de dezoito anos de idade, atendidos na Unidade de Referência de Doenças Infecciosas e Parasitárias Especiais e no Hospital Universitário João de Barros Barreto, na cidade de Belém, Pará, assim como analisar possíveis fatores de risco para as referidas infecções. Participaram do estudo 406 indivíduos que, após consentimento escrito, foram submetidos a exame físico, entrevista individual e coleta de $10 \mathrm{ml}$ de sangue destinada à pesquisa dos marcadores de infecção pelos vírus da hepatite B (HBsAg, anti-HBc e anti-HBs) e hepatite C (anti-VHCe VHC RNA viral). Os exames referentes à hepatite $\mathrm{B}$ e o anti-VHC foram realizados através de técnicas imunoenzimáticas de terceira geração e a pesquisa do VHC RNA foi realizada pela reação de polimerase em cadeia. A cada participante foi aplicado um questionário padronizado para obtenção de informações sobre as características socioeconômicas, demográficas e aos diversos fatores de risco investigados, referentes à exposição parenteral, sexual e intradomiciliar. A prevalência global de infecção pelo vírus da hepatite B foi de 51,0\% (IC:46,1 - 55,8), com
7,9\% para o $\mathrm{HBsAg}, 45,1 \%$ para o anti-HBc e $32,3 \%$ para o anti-HBs. Para o vírus da hepatite $\mathrm{C}$, a prevalência encontrada foi de 16,0\% (IC: 12,4 - 19,6). Fezse análise univariada em todas as variáveis investigadas e aquelas com valor de $\mathrm{p} \leq 0,25$ foram introduzidas em um modelo de regressão logística não condicional para pesquisa de associação com a infecção pelo vírus das hepatites B e C. Mostraram-se independentemente preditivas de infecção pelo vírus B as variáveis idade, cujo risco maior situou-se nas faixas etárias mais idosas; situação conjugal, com maior prevalência no grupo sem companheiro (solteiros, separados e viúvos) e preferência sexual, cujo risco situou-se no grupo dos homossexuais/bisse-xuais. A freqüência de infecção pelo vírus da hepatite $\mathrm{B}$ nos heterossexuais, bissexuais e homossexuais foi de $28,7 \%, 67,7 \%$ e $71,7 \%$, respectivamente. A infecção pelo vírus $\mathrm{C}$ mostrou-se associada, na análise multivariada, com as variáveis idade, cujo risco significante recaiu no grupo com 50 ou mais anos, antecedente de transfusão de sangue e uso de droga ilícita injetável. A prevalência de infecção pelo vírus da hepatite $\mathrm{C}$ entre os usuários de drogas injetáveis foi de $83,7 \%$ e de $22,1 \%$ na população de trans-fundidos.

\section{ANÁLISE CLÍNICA E LABORATORIAL NA SÍNDROME DE RESISTÊNCIA AO HORMÔNIO TIREÓIDEO}

\section{Gustavo Leopoldo Rodrigues Daré}

Orientadora: Profa. Dra. Léa Maria Zanini Maciel

Dissertação de Mestrado apresentada em 12/08/2002

A Síndrome de Resistência ao Hormônio Tireóideo (SRHT) é uma doença hereditária rara, causada, principalmente, por mutações no gene do receptor ß para o hormônio tireóideo, que foi descrita pela primeira vez em 1967, por Refetoff, DeWind e DeGroot. Os portadores da síndrome são, na maioria das vezes, assintomáticos, sendo geralmente identificados por apresentarem concentrações de $T_{3}$ e $T_{4}$ livres elevadas e concentração normal do hormônio estimulante da tireóide (TSH). Neste trabalho foram estudados 4 individuos portadores da SRHT, seguidos pela Divisão de Endocrinologia e Metabologia da Faculdade de Medicina de Ribeirão Preto - USP, e seus familiares, sendo que, além da caracterização clínica dos mesmos, foram avaliadas diversas variáveis que refletem o estado funcional de órgãos ou sistemas que sofrem a influência da ação dos hormônios tireóideos.
A avaliação clínica dos indivíduos afetados demonstrou grande variabilidade de manifestações: um dos indivíduos apresentou sintomas e sinais sugestivos de hipertireoidismo na infância, enquanto outro tinha, como principal queixa, taquicardia persistente, e dois outros eram, praticamente, assintomáticos. Porém, foi marcante a presença de bócio em todos eles. O acompanhamento clínico de dois indivíduos, diagnosticados na infância, demonstrou melhora dos sintomas durante a puberdade, bem como desenvolvimentos pônderoestaturais adequados. Concomitantemente à melhora da sntomatologia, em um destes indivíduos observouse tendência à normalização da concentração sérica do $\mathrm{T}_{3}$ possivelmente decorrente de alterações no metabolismo tecidual do $\mathrm{T}_{4}$ já que a concentração deste último, manteve-se elevada. Para a caracterização adequada da síndrome, os indivíduos afetados foram estudados após doses crescentes de $\mathrm{L}_{-} \mathrm{T}_{3}$. As respostas apresentadas por eles, em comparação àquelas observadas no grupo de indivíduos controles, demonstraram a resistência à ação dos hormônios tireóideos, princi- 
palmente em relação às variáveis que refletem a resistência em nível hepático (globulina transportadora de hormônios sexuais e ferritina) e hipofisário (TSH). $\mathrm{O}$ padrão de resposta dos tireotrofos às doses crescentes de $\mathrm{L}-\mathrm{T}_{3}$ foi discreto em 3 indivíduos afetados, demonstrando uma resistência leve, compatível com suas apresentações clínicas. Até hoje, poucos trabalhos foram conduzidos visando ao estudo do metabolismo ósseo nos indivíduos portadores da síndrome. Dois indivíduos afetados apresentaram concentrações de fósforo sérico baixas e um deles demonstrou osteopenia femoral associada. Outro indivíduo, adolescente, apresentou grande diminuição da densidade mineral óssea em coluna lombar e fêmur, sem apresentar alterações nas concentrações séricas de cálcio, fósforo ou paratohormônio. Essas observações indicam que a ocorrência de hipofosfatemia e diminuição da densidade óssea na SRHT, que não tem sido investigada na literatura, merece uma maior atenção dos pesquisadores. A análise do comportamento do grupo controle em resposta à sobrecarga aguda com $\mathrm{T}_{3}$ demonstrou, pela primeira vez, que a diminuição, causada pelo hormônio tireóideo, na concentração sérica de fósforo antecede a queda na concentração sérica do magnésio e do paratohormônio. Considerando-se a resposta sistêmica à hipofosfatemia e os mecanismos pelos quais o $\mathrm{T}_{3}$ diminui a concentração de fósforo sérico, esta observação sugere a possibilidade de o fósforo ser um dos principais fatores que interligam os efeitos dos hormônios tireóideos no metabolismo intermediário, com os efeitos sobre o metabolismo ósseo. A análise do comportamento do grupo controle em resposta à sobrecarga com $\mathrm{T}_{3}$ também demonstrou a capacidade dos hormônios tireóideos contra-regularem a concentração sérica da globulina transportadora de tiroxina.

\section{RECONHECIMENTO DE PADRÃO ANATÔMICO PARA INDEXAÇÃO E RECUPERAÇÃO DE IMAGENS DE TOMOGRAFIA COMPUTADORIZADA A PARTIR DE CONTEÚDO}

\begin{abstract}
André Luiz Mendes Matos
Orientador: Prof. Dr. Paulo M. de Azevedo Marques

Dissertação de Mestrado apresentada em 06/09/2002
\end{abstract}

Este trabalho apresenta a pesquisa e o desenvolvimento de um algoritmo baseado em Redes Neurais Artificiais (RNAs) para reconhecimento de padrões anatômicos em imagens de Tomografia Computadorizada (TC), visando a indexação e recuperação de imagens com base em conteúdo pictórico dentro de sistemas de arquivamento e comunicação de imagens (Picture Archiving and Communication Systems - PACS).

Foi realizada uma etapa de pré-processamento para posterior inserção de padrões na Rede Neural Artificial (RNA). Nesta etapa, realizou-se a redução do tamanho das imagens, extração das assinaturas das linhas de cada imagem e posterior cálculo de entropia, em cada uma das assinaturas obtidas, buscando uma medida de informação. Estas medidas foram então utilizadas como padrões na RNA.

A RNA utilizada foi a "Feed-forward" contemplando o algoritmo "backpropsgstion". Sua arquitetura é composta de três camadas, sendo uma camada de entrada, uma camada oculta e uma camada de saída. A RNA apresentou um desempenho de reconhecimento dos padrões anatômicos de 97,39\% de acerto.

\section{LESÃO GÁSTRICA EXPERIMENTAL POR INDOMETACINA - PAPÉIS DO ÓXIDO NÍTRICO (NO) E DO FATOR DE NECROSE TUMORAL $\alpha$ (TNF- $\alpha$ ), E AVALIACÃO DO TÔNUS GÁSTRI- CO E DO ESVAZIAMENTO GÁSTRICO DE LÍQUIDOS}

\section{Marcellus Henrique Loiola P. de Souza \\ Orientador: Prof. Dr.Ricardo Brandt de Oliveira \\ Tese de Doutorado apresentada em 10/10/2002}

Introdução: A principal complicação do uso dos AINEs é a lesão gastrintestinal. O papel do NO na lesão gástrica (LG) por AINEs ainda foi estabelecido. O TNF- $\alpha$ está envolvido na gastropatia por AINEs, mas o papel do TNF-R1 ainda não foi esclarecido. A dismotilidade do antro gástrico tem sido implicada na fisiopatologia da $\mathrm{LG}$ por indometacina (INDO), mas a relação entre as anormalidades motoras gástricas e as lesões na mucosa não foram totalmente investigadas. Objetivos: 1) Reproduzir modelos de LG por INDO em ratos e em camundongos C57BL/6; 2) No estômago destes modelos, verificar o papel do NO sobre a LG e a infiltração neutrofílica (IN); 3) Verificar o papel do TNF- $\alpha$ sobre a LG e IN em camundon- 
gos; 4) Investigar o papel da NO sintase induzida e do TNF-R1 na LG por INDO, utilizando-se camundongos deficientes; 5) Verificar, em ratos, se os efeitos da INDO sobre a mucosa gástrica se associam com anormalidades do tônus gástrico (TG) e do esvaziamento gástrico de líquidos (EG). Métodos: A LG e a IN em ratos e em camundongos foram induzidas por diferentes doses de INDO e avaliadas em vários intervalos de tempo. O índice de lesão (IL) foi calculado através da soma das extensões das lesões encontradas na mucosa. A IN foi determinada pela atividade da mieloperoxidase. Diferentes grupos de ratos receberam L-NAME. N-nitro-arginina, aminoguanidina, L- arginina, D-arginina, L-lisina ou fucoidina. Após 1 hora, a LG foi induzida por INDO na dose de $5 \mathrm{mg}$. $\mathrm{Kg}^{-1}$ (INDO-5) ou na dosse de $20 \mathrm{mg} . \mathrm{Kg}^{-}$ ${ }^{1}$ (INDO-20). Três horas após, a LG e a IN foram determinadas. Diferentes grupos de camundongos receberam talidomida, dexametasona, fucoidina, LNAME. Após 12 horas da administração de INDO, foram avaliadas a LG e a IN. Camundongos deficientes para o TNF-R1 (TNF-R1-/-) ou para a NOSi (NOSi-/-) ou não deficientes receberam INDO. Após 12 horas, a LG e a IN foram determinadas. Após $1 \mathrm{ou}$ 3 horas de INDO-5 ou INDO-20, TG foi aferido através do método de pletismometria e a retenção gástrica $(R G)$ de salina ou de Sustacal $®$ foi determinada por cintilografia. Resultados: A INDO induziu uma LG e IN dose dependentes com efeito máximo na dose de $20 \mathrm{mg} . \mathrm{Kg}^{-1}$ nos ratos e $10 \mathrm{mg} . \mathrm{Kg}^{-1}$ nos camundongos. A LG e a IN apresentaram máximas intensidades com 3 horas nos ratos e 12 horas nos camundongos. Nos ratos, os tratamentos com L- NAME, Nnitro- arginina e aminoguanidina inibiram a LG induzida por INDO-20, mas não a por INDO-5. Os tratamentos com L- NAME e N- nitro- arginina aumentaram a IN induzida tanto por INDO-5 como por INDO-20. $\mathrm{O}$ tratamento com L- arginina, mas não com D-arginina ou L- lisina, inibiu a LG induzida por INDO-20. O tratamento com flucoidina inibiu tanto a LG quanto a IN induzidas por INDO-20, mas não a por INDO-5. Em camundongos, a LG e a IN foram reduzidas pelo tratamento com talidomida, dexametasona ou flucoidina. Após a administração de INDO, o TNF-R1-/- apresentou uma LG e uma IN menor que os controles. O tratamento com L-NAME inibiu a LG, mas aumentou a IN induzida por INDO. Apesar da intensa IN, os animais NOSi-/- apresentaram uma LG menor que a dos controles. Uma hora ou $3 \mathrm{~h}$ após, tanto da INDO5 quanto da INDO-20, observou-se que o TG foi menor que o do controle. A RG de salina após 1 hora, tanto do grupo INDO-5 quanto do grupo INDO-20, foi maior que a do controle. Após 3 horas da INDO, não se observaram estas diferenças. Não houve diferenças na RG de Sustacal ${ }^{\circledR}$ entre os vários grupos. Conclusões: 1) Os modelos de LG por INDO em ratos e camundongos foram reprodutíveis; 2) Os tratamentos com inibidores da NOS reduziram a LG por INDO-20, mas não a por INDO-5. Este efeito não se deve a redução na IN; 3) $\mathrm{O}$ tratamento com a $\mathrm{L}$ arginina inibiu a LG por INDO-20. Este efeito é específico, pois nem a D- arginina, nem a L - lisina foram capazes de reproduzir esta proteção; 4) O NO gerado a partir da NOSi está envolvido na LG por INDO em camundongos, através de um mecanismo independente da redução na IN; 5) A LG por INDO-20, mas não a por INDO-5, é dependente da IN: 6) Em camundongos, o TNF- $\alpha$ através da sinalização do TNF-R1, é para a LG e para a IN por INDO; 7) Na gastropatia por INDO, a diminuição no TG e o retarde do EG precedem a LG e a IN, sugerindo que estas alterações motoras não dependem da lesão da mucosa.

\section{DETERMINAÇÃO DO LIMIAR DE ANAEROBIOSE VENTILATÓRIO NO EXERCÍCIO FÍSICO DINÂMICO EM INDIVÍDUOS SADIOS. COMPARAÇÃO ENTRE MÉTODOS OBTIDOS POR ANÁLISE VISUAL E MODELOS MATEMÁTICOS}

\section{Júlio César Crescêncio}

Orientador: Prof. Dr. Lourenço Gallo Jr.

Dissertação de Mestrado apresentada em 24/10/2002

Os avanços tecnológicos ocorridos na última década trouxeram enormes benefícios, no sentido de possibilitar o uso de equipamentos computadorizados, que permitem a aquisição, processamento e armazenamento de um grande número de variáveis respirató- rias e metabólicas em exercício físico, em tempo real e de ciclo a ciclo respiratório.

Dentro deste novo cenário, o estudo realizado com esta nova geração de equipamentos, nas respectivas áreas de conhecimento, pôde ser direcionado, usando-se métodos matemáticos e estatísticos computadorizados, os quais possibilitam a aplicação de procedimentos automáticos e/ou semi-automáticos na solução de problemas específicos. 
É dentro deste contexto que se insere o presente estudo, que tem por objetivo comparar, em indivíduos sadios do sexo masculino, o limiar de anaerobiose ventilatório, durante o exercício fisico dinâmico, usando-se métodos visuais gráficos e métodos baseados em modelos matemáticos, automáticos e semi-automáticos.

Foram estudados 24 voluntários sadios do sexo masculino, com idade média de 33,8 $\pm 9,25$ anos.

Todos eles se submeteram a um ou dois testes de esforço físico dinâmico, segundo um protocolo contínuo do tipo rampa, na posição sentada, em cicloergômetro eletromagnético, acoplado a um sistema ergoespirométrico computadorizado (CPX/D MedGraphics), que possibilita o cálculo de múltiplas variáveis cardiorrespiratórias, como: ventilação pulmonar $(V E)$, produção de $\mathrm{CO}_{2}\left(V \mathrm{CO}_{2}\right)$, consumo de $0_{2}$ $\left(V \mathrm{O}_{2}\right)$, equivalentes ventilatórios de $0_{2}\left(V \mathrm{E} / \mathrm{VO}_{2}\right)$ e de $\mathrm{CO}_{2}\left(V \mathrm{E} / V \mathrm{CO}_{2}\right)$, frações parciais do $0_{2}\left(\mathrm{PETO}_{2}\right)$ e do $\mathrm{CO}_{2}\left(\mathrm{PETCO}_{2}\right)$ no final da expiração, quociente de trocas respiratórias (RER), frequiências respiratória (RR) e cardíaca (FC), além dos valores de potência aplicada e da velocidade de pedalagem no cicloergômetro.

Os valores do LAV em exercício foram calculados por quatro diferentes métodos, que usam como critério de medida deste parâmetro, a mudança da inclinação da $V \mathrm{CO}_{2}$, da $V \mathrm{E}$ e do PET $0_{2}$ em relação ao tempo ou da $\mathrm{VCO}_{2}$ em relação ao $\mathrm{VO}_{2}$. Estes métodos foram os seguintes: 1- método Visual VC02 (M. VISUAL $V \mathrm{CO}_{2}$ ); 2- método Visual PET $0_{2}$ (M. VISUAL PET $\mathrm{O}_{2}$ ); 3- método Automático, usando algoritmo, incorporado ao sistema MedGraphics (M. AUTOMÁTICO); 4- método semi-automático, implementado em nosso Laboratório, baseado no uso de modelos bissegmentados Linear-Linear (M. L-L $\mathrm{VCO}_{2}$ ) e Linear-
Quadrático (M. L-Q $V \mathrm{CO}_{2}$ ) na condição de resposta da $V \mathrm{CO}_{2}$ em relação ao tempo e em relação ao $V 0_{2}$ (M.L-L $V \mathrm{CO}_{2}-\mathrm{VO}_{2}$ e M. L-Q $V \mathrm{CO}_{2}-V \mathrm{O}_{2}$ ).

Os modelos bissegmentados se basearam na aplicação da soma dos quadrados dos resíduos, quando o conjunto de dados é ajustado pelo método dos mínimos quadrados, para uma reta inicial e final ou uma reta inicial e uma curva quadrática final.

Após análise qualitativa e quantitativa apropriada ao conjunto de dados, chegou-se às seguintes conclusões: 1- os valores da LAV calculados pelos métodos visuais $V \mathrm{CO}_{2}$ e PET $\mathrm{O}_{2}$ foram significativamente superiores $(\mathrm{p}<0,05)$ aos obtidos pelos métodos Automático e L-L $V \mathrm{CO}_{2}$; 2- o método Visual $\mathrm{VCO}_{2}$ mostrou melhor desempenho do que o método Visual PET $0_{2}$; 3- os valores do LAV calculados pelos métodos Automático e L-L $V \mathrm{CO}_{2}$ não foram estatisticamente diferentes e ambos subestimaram os valores do LAV, comparativamente aos métodos visuais $V \mathrm{CO}_{2}$ e PET $\mathrm{O}_{2}(\mathrm{p}<0,05) ; 4$ - os métodos baseados em modelos bissegmentados L-L e L-Q mostraram que somente o M. L-L, para o caso da resposta da $V \mathrm{CO}_{2}$ em relação ao tempo, foi útil para medir quantitativamente o LAV; 5o método semi-automático bissegmentar L-L $\mathrm{VCO}_{2}$ mostrou melhor desempenho do que o método Automático, quando ambos foram comparados qualitativa e quantitativamente (maior porcentagem de casos em que foi possível aplicar o modelo e melhor comportamento dos parâmetros das regressões lineares do LAV, relacionando potência e $\mathrm{VO}_{2}$ ); 6- o método semi-automático bissegmentar L-L VCO2 se mostrou promissor, no sentido de que possa ser aprimorado e usado, em futuro próximo, como método totalmente automático de determinação do limiar de anaerobiose ventilatório durante o exercício físico dinâmico.

\section{UTILIZAÇÃO DA TOMOGRAFIA COMPUTADORIZADA SEM CONTRASTE E DA RESSO- NÂNCIA MAGNÉTICA NO DIAGNÓSTICO E NA ESTRATIFICAÇÃO DA GRAVIDADE DA PANCREATITE AGUDA}

\section{Jorge Elias Júnior}

Orientador: Prof. Dr. Clóvis Simão Trad

Tese de Doutorado apresentada em 22/11/2002

A pancreatite aguda (PA) é uma doença potencialmente letal, com ampla variação nos aspectos clínicos e de gravidade, podendo ser leve e autolimitada num extremo e rapidamente progressiva, levando a falência de múltiplos órgãos e morte, no outro. Durante os últimos anos ocorreram muitas mudanças no aten- dimento de pacientes com PA. Dentre estas mudanças estão a clara necessidade de tratamento em unidade de terapia intensiva para os casos de PA grave e a perspectiva, cada vez mais presente, de tratamento com drogas antiinflamatórias específicas. Para isso, é preciso que se obtenha a estratificação da gravidade o mais rápido possível, o que é feito por meio de índices clínico-laboratoriais e da Tomografia Computadorizada (TC). A utilização da TC para o estudo da PA tem sofrido críticas quanto à sua utilidade e quanto 
aos riscos relacionados ao uso do contraste iodado endovenoso (EV), tanto pelos riscos gerais de reação alérgica, quanto pelo risco de levar à piora do quadro, por alteração da microcirculação pancreática e aumento da área de necrose. No presente estudo avaliamos a utilidade da TC sem contraste EV e da Ressonância Magnética (RM) no diagnóstico e estratificação de gravidade da PA em 105 pacientes, sendo que em 96 foi feita a TC completa, em 95 foi obtida a TC sem contraste EV e em 45 foi realizada a RM. Os métodos foram comparados entre si, considerando a TC completa com o método de referência. Houve correlações significativas entre os índices obtidos, assim como existiram associações significativas entre os subgrupos estudados. Considerando somente a necrose pancreática, observamos correlação entre o índice morfológico obtido pela TC sem contraste EV e o índice de necrose, sendo possível verificar, também, que a TC sem contraste EV teve associação com o índice de necrose. Foram realizados, também, estudos de correlação e de associação entre a classificação clínicolaboratorial APACHE II e os métodos de imagem, os quais não foram significativos, indicando a necessidade de obtenção de estudo por imagem do pâncreas, na estratificação de gravidade da PA. Portanto, nossos resultados indicam que a TC sem contraste EV pode ser utilizada como método para diagnóstico e estratificação de gravidade da PA, abrindo a possibilidade da utilização mais ampla e irrestrita desta técnica para o estudo morfológico do pâncreas nesta situação, sem qualquer risco para o paciente. Adicionalmente, confirmamos que a RM é uma opção real para o diagnóstico e a estratificação de gravidade da PA, devendo ser utilizada principalmente nos casos de pancreatite biliar, indicando melhor o tipo de tratamento a ser realizado.

\section{ESTUDO CLÍNICO-EPIDEMIOLÓGICO SOBRE A HANTAVIROSE NA REGIÃO DE RIBEIRÃO PRETO, SP}

\section{Gelse Mazzoni Campos}

Orientador: Prof. Dr. Luiz Tadeu Morais Figueiredo

Dissertação de Mestrado apresentada em 29/11/2002

As hantaviroses são zoonoses de roedores silvestres que causam doenças humanas graves: febre hemorrágica com síndrome renal na Ásia e Europa, com letalidade de 10 a $12 \%$ e no continente americano causam a Síndrome Pulmonar e Cardiovascular por Hantavirus (SPCVH), letalidade de 59\%.

Os Hantavirus (familia Bunyaviridae) são vírus envelopados que medem aproximadamente $120 \mathrm{~nm}$, possuem RNA de fita simples e polaridade negativa, dividida em 3 segmentos (L, M e S) que se replicam no citoplasma. A infecção humana relaciona-se à inalação de aerossóis de excretas de roedores infectados com Hantavirus, embora existam relatos de transmissão interpessoal na América do Sul. No Estado de São Paulo, os roedores infectados mais encontrados foram o "rato do rabo peludo" (Bolomys lasiurus), o " rato da mata" (Akodon cursor) e o " ratinho do arroz" (Oligoryzomys negrips).

Desde os 3 primeiros casos de hantavirose descritos no Brasil (1993) com indivíduos moradores da área rural de Juquitiba, SP, evidenciando o primeiro surto conhecido de SPCVH, mais de uma centena de casos da SPCVH foram notificados, causando 60 óbitos (letalidade de 46\%).
Na região de Ribeirão Preto, ocorreram quatorze casos de SPCVH de 1998 a 2001, com letalidade de $64,2 \%$, o que motivou este trabalho.

Um primeiro objetivo deste trabalho foi estudar aspectos clínicos e epidemiológicos dos casos de hantavirose ocorridos na região de Ribeirão Preto, de 1998 a 2001, para conhecer o comportamento das hantaviroses nesta região. Analisando e acompanhando prontuários de 14 pacientes com SPCVH, observou-se febre ( $100 \%$ dos casos), estertores pulmonares, dispnéia e tosse $(64,2 \%)$, taquicardia acompanhada de hipotensão $(64,2 \%)$, cefaléia e sintomas digesti$\operatorname{vos}(57 \%)$, adinamia e indisposição geral (50\%), fenômenos hemorrágicos $(28,5 \%)$, mialgia $(21,4 \%)$ e convulsão $(7,5 \%)$. No perfil laboratorial, a plaquetopenia $<130000 / \mathrm{mm}^{3}(100 \%)$, hematócrito > 55\%, (78,6\%); leucocitose $>15000 / \mathrm{mm}^{3}(64,2 \%)$, neutrofilia $>7000 /$ $\mathrm{mm}^{3}$ e bastonetes $>600$ cels $/ \mathrm{mm}^{3}(64,2 \%)$, creatinina sérica $>1,5 \mathrm{mg} / 100 \mathrm{ml}(63,6 \%)$ e $\mathrm{PO}_{2}<70 \mathrm{mmHg}$ $(54,5 \%)$. O diagnóstico laboratorial das hantaviroses foi feito por ELISA para igM e IgG anti Sin Nombre após a alta.

Houve diferença significativa entre casos fatais e sobreviventes, quanto à época de suspeita diagnóstica de hantavirose $(\mathrm{p}=0,0152)$ e quanto ao uso de hidratação parenteral $(\mathrm{p}=0,0152)$ : nos sobreviventes, a suspeita diagnóstica de SPCVH foi feita entre o $1^{\circ} \mathrm{e}$ o $2^{\circ}$ dia de internação e, nos casos fatais a suspeita foi 
feita apenas a necropsia. Existe uma correlação significativa entre o volume de infusão endovenosa de liquidos $\geq 2500 \mathrm{ml}$, nas primeiras $24 \mathrm{~h}$ de tratamento, e a evolução dos casos para o óbito. A oxigenação precoce, ventilação mecânica, assim como o uso de aminas vasoativas e o de corticosteróides não tiveram associação com sobrevida e a presença de choque não teve associação com óbito.

O segundo objetivo foi estudar a prevalência de anticorpos Hantavírus na população de Jardinópolis, na região de Riberão Preto, SP. Em estudo prévio entre cidades da região de Ribeirão Preto, obteve-se maior índice de prevalência sorológica $(4,5 \%)$ para Hantavirus naquele município.

Através de coleta aleatória em parte da área rural e em toda a área urbana, obtivemos 818 amostras de sangue de moradores entre 15 e 70 anos, por digitopuntura em papel de filtro, dos quais coletamos dados relevantes como idade, sexo, cor, procedência, atividade profissional, endereço, telefone: moléstia atual, medicamentos em uso, pnemonia grave pregressa, tipo de moradia, número de moradores na casa, esgoto, coleta de lixo, celeiro, contato com roedores . Essas amostras foram processadas nas diluições 1/50, 1/100, 1/400 e 1/1600 e submetidas ao ELISA indireto para detecção de IgG para Hantavirus Andes. Os resultados foram analisados pelo teste de Fisher e teste do Qui-quadrado, utilizando o programa InSat 3.0 (GraphPad Software Inc, USA) e para $\alpha$ de 5\%, com intervalo de confianca de $95 \%$. A possibilidade geral foi de $14,3 \%$ com ELISA à diluição $1 / 50$, na zona urbana foi de $15,3 \%$ e na zona rural de $6,5 \%$, demonstrando alta representatividade para a população do município de Jardinópolis.

Entre moradores de zona urbana e rural, a positividade para Hantavirus foi significativamente maior para os moradores urbanos $(\mathrm{p}=0,0183)$. E entre as diferentes faixas etárias com a das restantes, observou-se diminuição significativa para a faixa etária de 21 a 30 anos $(\mathrm{p}=0,0117)$ e aumentada para a de 31 a 40 anos $(p=0,0036)$. Não houve diferença significativa de positividade para Hantavirus observada nos homens e nas mulheres $(\mathrm{p}=0,0892)$, nem para indivíduos com atividade profissional urbana e rural $(\mathrm{p}=0,8799)$, nem com os indivíduos que referiram pneumonia grave $(\mathrm{p}=0,6096)$ e da mesma forma nos indivíduos que declararam contato com roedores $(\mathrm{p}=0,4842)$. Assim como não houve associação entre títulos de 100 e 400 para as mesmas características analisadas.

\section{RELAÇÕES ENTRE A DISTRIBUIÇÃO INTRAGÁSTRICA DE UMA REFEIÇÃO LÍQUIDA E EPISÓDIOS DE REFLUXO NA DOENÇA DO REFLUXO GASTRO-ESOFÁGIÇO}

\section{José Ruver Lima Herculano Júnior}

Orientador: Prof. Dr. Luiz Ernesto de Almeida Troncon

Tese de Doutorado apresentada em 17/12/2002

A distensão das paredes gástricas constitui um potente estímulo desencadeador de relaxamentos transitórios do esfíncter inferior do esôfago, mas são escassos os conhecimentos acerca da função motora do estômago proximal e da distribuição intragástrica do conteudo alimentar, na doença do refluxo gastroesofágico (DRGE).

Este estudo teve como objetivo avaliar os perfis do esvaziamento gástrico e da distribuição intragástrica e suas possíveis influências sobre a ocorrência dos episódios de refluxo, em pacientes com a DRGE.

O esvaziamento gástrico e a distribuição intragástrica de uma refeição de prova líquida foram estudados por método cintilográfico em 12 voluntários assintomáticos e em 19 pacientes com a DRGE. Os pacientes submeteram-se, também, à manometria esofágica e ao estudo $\mathrm{pH}$-métrico pós-prandial de duas horas, usando a mesma refeição de prova líquida, seguido de $\mathrm{pH}$-metria de $24 \mathrm{~h}$.

Os resultados obtidos evidenciaram que:

1) não houve diferença estatisticamente significativa, entre pacientes com DRGE e controles, com relação ao esvaziamento gástrico;

2) houve redução significativa da retenção alimentar no estômago proximal, em pacientes com DRGE com relação a controles ( $\mathrm{ASC}_{\mathrm{prox}} / \mathrm{ASC}_{\text {tot }}$ - média; desvio padrão: 0,$568 ; 0,06$ vs. 0,$486 ; 0,07 ; p=0,026$;

3) nos pacientes com a DRGE, houve significativa correlação linear negativa entre os valores da retenção alimentar no estômago proximal e o número de episódios de refluxo gastroesofágico ocorrido, tanto no estudo $\mathrm{pH}$-métrico pós-prandial $(\mathrm{r}=-0,69 ; \mathrm{p}=0,005)$, como no de 24 horas $(r=-0,66 ; p p=0,005)$.

Em conclusão, os dados obtidos sugerem que pacientes com a DRGE têm retenção de líquidos no estômago proximal anormalmente diminuída e que esta alteração parece contribuir para a patogênese dos episódios de refluxo. 


\section{USO DA MINI-AVALIAÇÃO NUTRICIONAL COMO UM MÉTODO DE AVALIAÇÃO DE RISCO DE DESNUTRIÇÃO EM IDOSOS DE UMA COMUNIDADE DE RIBEIRÃO PRETO, SP.}

\author{
Roberta Rigo Dalacorte \\ Orientador: Prof. Dr. Eduardo Ferrioli \\ Dissertação de Mestrado apresentada em 20/12/2002
}

O estado nutricional dos idosos é estreitamente relacionado com seu estado imunológico e de saúde em geral, sendo o diagnóstico nutricional de grande importância nessa faixa etária. As opiniões diferem quanto ao método preferível no diagnóstico de desnutrição em idosos, utilizando-se, habitualmente, uma avaliação clínica detalhada associada a medidas antropométricas e avaliação bioquímica. Diversas escalas foram propostas para a avaliação nutricional simplificada, sendo a mais freqüentemente utilizada, hoje, a Mini Avaliação Nutricional. O presente estudo teve como objetivos estimar o desempenho da Mini Avaliação Nutricional no diagnóstico de desnutrição ou do risco de desnutrição em indivíduos idosos oriundos de uma comunidade de Ribeirão Preto-SP, bem como avaliar por parâmetros clínicos, antropométricos e laboratoriais, o estado nutricional desses idosos e comparar os escores obtidos na Mini Avaliação Nutricional com os dados obtidos através desses parâmetros. Quarenta e dois idosos foram estudados (55\% do gênero feminino, média de idade 70,9 anos). No diagnóstico nutricional final, três voluntários $(7,1 \%)$ eram desnutridos e 12 voluntários $(28,6 \%)$ eram obesos. Os outros 27 voluntários eram eutróficos. Pela MAN, nenhum dos voluntários foi classificado como desnutri- do, 13 foram classificados como em risco de desnutrição e 29 obtiveram pontuação normal. Quando comparado ao diagnóstico nutricional final, o desempenho diagnóstico da MAN mostrou sensibilidade de 100\% e especificidade de 74,3\% embora o número de voluntários estudados limite essa comparação. Os voluntários classificados como em risco pela MAN que eram eutróficos ou obesos foram avaliados individualmente e detectou-se a presença de vários fatores clínicos que são considerados de risco para desnutrição, como diminuição involuntária da ingestão de alimentos, perda involuntária de peso nos últimos três meses, uso de múltiplas medicações continuamente, presença de duas ou mais doenças crônicas, hábito alimentar equivocado, com baixa ingestão de proteínas e alimentos reguladores e alta ingestão de carbohidratos e auto-avaliação pessimista de seu estado nutricional e de saúde. Considerando-se esses aspectos, dos 10 voluntários classificados como em risco pela MAN e que não tinham diagnóstico nutricional final de desnutrição, pode-se dizer que oito estavam em risco de desnutrição pela conjunção de fatores clínicos e dietéticos. Conclui-se que os voluntários desse estudo apresentaram prevalência de desnutrição equivalente à de idosos vivendo em outras comunidades brasileiras e em países desenvolvidos e que a Mini Avaliação Nutricional é um teste rápido e fácil de ser aplicado, sendo que, para essa amostra de indivíduos, ela demonstrou ser eficaz, principalmente, para detecção de indivíduos em risco de desnutrição.

\section{FARMACOLOGIA}

\section{PARTICIPAÇÃO DO ÓXIDO NÍTRICO NA ELABORAÇÃO DE RESPOSTAS AVERSIVAS PELO COLÍCULO INFERIOR E PELA MATÉRIA CINZENTA PERIAQUEDUTAL DORSOLATERAL DE RATOS}

Fabrício de Araújo Moreira

Orientador: Prof. Dr. Francisco Silveira Guimarães

Dissertação de Mestrado apresentada em 15/08/2002

O óxido nítrico (NO) é um neurotransmissor gasoso, sintetizado após a ativação receptores NMDA para glutamato. A enzima de síntese do NO (sintase do óxido nítrico, NOS), está presente em estruturas do sistema nervoso central responsáveis pela elaboração de respostas a eventos aversivos, como Matéria Cinzenta Periaquedutal Dorsolateral (MCPDL) e Colículo Inferior (CI). A estimulação elétrica ou química destas estruturas, em ratos, desencadeia comportamentos de natureza aversiva (reações de fuga). É possível 
que o NO participe da elaboração destes comportamentos pela MCPDL, uma vez que injeções locais de inibidores de NOS resultam em efeito ansiolítico no modelo do labirinto em cruz elevado (LCE), enquanto a de doadores de NO) (SIN-1 ou DEA/NO) resulta em respostas aversivas de fuga.

O objetivo deste trabalho foi o estudo da participação do NO em eventos aversivos desencadeados a partir do CI ou da MCPDL.

Injeção de doador de NO (SIN-1, $300 \mathrm{nmol})$, no núcleo central (mas não no córtex dorsal) do CI de ratos Wistar machos, resultou em reação de fuga caracterizada por aumento de distância percorrida, saltos e galopes em ratos submetidos ao modelo do campo aber- to. Este efeito foi parcialmente inibido pelo pré-tratamento (10 min) com inibidor da guanilato ciclase (azul de metileno, $100 \mathrm{nmol}$ ), e impedido por pré-tratamento (10 $\mathrm{min}$ ) com antagonista de receptores NMDA (AP7, $2 \mathrm{nmol})$. O pré-tratamento com AP7 também impediu os efeitos do SIN-1 na MCPDL. Injeção de inibidor da NOS (L-NAME, 50, 100 ou $200 \mathrm{nmol}$ ) no núcleo central do CI não resultou em efeito ansiolítico no modelo do LCE, ao contrário do que já se observou na MCPDL.

Estes resultados sugerem a participação de NO na elaboração de respostas aversivas pelo CI, além da MCPDL. Estes efeitos do NO dependem da ativação de receptores glutamatérgicos do tipo NMDA, tanto no CI quanto na MCPDL.

\section{IDENTIFICAÇÃO DE PEPTÍDEOS DO SISTEMA RENINA-ANGIOTENSINA COM ATIVIDADE ANTINOCICEPTIVA NA SUBSTÂNCIA CINZENTA PERIAQUEDUTAL DE RATOS}

\section{Adriana Pelegrini da Silva}

Orientador: Prof. Dr. William Alves do Prado

Tese de Doutorado apresentada em 27/08/2002

O efeito antinociceptivo da microinjeção de Ang II na região ventrolateral da substância cinzenta periaquedutal (PAG), assim como de seus precursores, tetradecapeptídeo substrato da renina e Ang I (Prado et al. Submetido), associado à presença de receptores $\mathrm{AT}_{1}$ e $\mathrm{AT}_{2}$ detectados nesta área por imunohistoquímica, indicam que o sistema renina-angiotensina deve ter participação no controle da transmissão nociceptiva no sistema nervoso central. Observamos aqui que a Ang II reduz a alodinia mecânica desencadeada por incisão cirúrgica da pata de ratos. Sustentando a participação do sistema renina-angiotensina endógena na modulação nociceptiva tônica mediada pela PAG, observamos que antagonistas seletivos dos receptores $\mathrm{AT}_{1} \mathrm{e} \mathrm{AT}_{2}$, microinjetados nesta área, intensificam o comportamento nociceptivo dos animais.

No entanto, o efeito antinociceptivo da Ang II, Ang III e Ang I parece depender da produção endógena de metabólitos ativos, pois inibidores enzimáticos, como a amastatina ou bestatina, bloqueiam tal atividade (Pelegrini da Silva 1998, esta tese). Assim avaliamos in vitro se a PAG possui maquinaria enzimática necessária para produzir fragmentos com propriedades analgésicas. A análise por cromatografia líquida de alto desempenho (HPLC) indica que o homogeneizado de "punches" da região ventrolateral da PAG incubado com Ang II produz rápida clivagem deste peptídeo em Ang III, Ang IV, Ang II (1-7) e fragmentos como a Ang II (1-4) e Ang II (5-8). A incubação de Ang III também produz estes fragmentos, exceto a Ang II (1-4), pois a Ang III não possui o ácido aspártico amino-terminal da Ang II, e um produto extra, a Ang II (4-8). Todos os peptídeos detectados, exceto a Ang II (1-4), aumentam o limiar nociceptivo dos animais no teste de retirada de cauda. Além disso, a Ang II (5-8), o menor produto formado detectado nos sistemas cromotográficos I e II, não tem atividade antinociceptiva detectável via $\mathrm{AT}_{1}$ ou $\mathrm{AT}_{2}$.

A Ang II e seus produtos de hidrólise são susceptíveis à hidrólise enzimática. A análise da hidrólise da Ang II e de seus fragmentos na presença de inibidores enzimáticos, usando HPLC, pode ajudar a determinar a importância destas enzimas na produção endógena do(s) peptídeo(s) ativo(s) no controle nociceptivo da PAG. A Ang II é hidrolisada principalmente por aminopeptidases sensíveis à amastatina. Além disso, este inibidor também reduz a hidrólise da Ang II (5-8). As metalopeptidases parecem ser importantes no metabolismo da ligação $\mathrm{Tyr}^{4}-\mathrm{Ile}^{5} \mathrm{e}$, aparentemente também da ligação $\mathrm{Pro}^{7}-\mathrm{Phe}^{8}$. A prolil-endopeptidase não parece participar significativamente do metabolismo dos peptídeos do sistema renina-angiotensina na PAG.

Considerando o paradigma dos inibidores enzimáticos, sugerimos que fragmentos carboxi-terminais derivados da hidrólise de Ang II por aminopeptidases e metalopeptidases desencadeiam antinocicepção a partir da PAG. Os resultados indicam também, pela 
primeira vez, que fragmentos da Ang II, antes considerados produtos metabólicos inativos, são capazes de produzir analgesia a partir da PAG no teste de retira- da de cauda. Além disso, a Ang II (5-8) parece produzir seu efeito antinociceptivo pela ativação de receptores diferentes do $\mathrm{AT}_{1}$ e $\mathrm{AT}_{2}$.

\section{EVIDÊNCIAS DA PARTICIPAÇÃO CININÉRGICA NO DESENOLVIMENTO DA RESPOSTA FEBRIL EM RATOS}

\section{Danielle Rodrigues dos Santos}

Orientadora: Profa. Dra. Glória Emília Petto de Souza Tese de Doutorado apresentada em 07/11/2002

Tem sido demonstrado que a administração intracerebroventricular de cininas induz elevação da temperatura corporal em animais experimentais. Entretanto, os mediadores envolvidos nesta resposta e o envolvimento do sistema cininérgico no desenvolvimento da resposta febril em resposta a pirogênicos exógenos ainda não foram estabelecidos.

Os objetivos deste estudo foram investigar a participação do sistema cininérgico na resposta febril induzida pela administração intravenosa de LPS e nas respostas febris induzidas por vários pirogênicos endógenos, como as citocinas, CRF e PFPF, e também investigar os mediadores envolvidos no efeito pirogênico induzido pela administração central de bradicinina (BK) em ratos.

Foi verificado que o tratamento sistêmico ( $1 \mathrm{mg} /$ $\mathrm{Kg}$, iv) ou central (20 nmol, icv) com o antagonista seletivo para receptores $B_{2}$, $\mathrm{HOE}-140$, reduziu de forma significativa a resposta febril induzida pela administração intravenosa de $5 \mu \mathrm{g} / \mathrm{Kg}$ de LPS. Por outro lado, estes tratamentos não alteraram a resposta induzida pela administração de uma maior dose de LPS $(50 \mu \mathrm{g} / \mathrm{Kg}, \mathrm{iv})$. O tratamento iv ou icv com antagonista seletivo para receptores $\mathrm{B}_{1}$, des-Arg ${ }^{9}-\left[\mathrm{Leu}^{8}\right]-\mathrm{BK}$ (DALBK), não alterou a resposta febril induzida pela administração de LPS $(5 \mu \mathrm{g} / \mathrm{Kg}$, iv). Além disso, animais tratados com captopril $(5 \mathrm{mg} / \mathrm{Kg}$, sc. 1 hora antes) apresentaram exacerbação da resposta febril induzida pelo LPS $(5 \mu \mathrm{g} / \mathrm{Kg}$, iv), sendo este efeito totalmente revertido pelo tratamento iv com HOE-140. Estes resultados sugerem a participação das cininas endógenas na resposta febril induzida pela administração intravenosa de baixas doses de endotoxina pela ativação de receptores do tipo $\mathrm{B}_{2}$, possivelmente localizados no sistema nervoso central.

Foi observado que a administração intravenosa de LPS $(5 \mu \mathrm{g} / \mathrm{Kg})$ induziu significativo aumento dos níveis de BK livre, cinininogênio total e calicreína tecidual no fluido cerebroespinal de animais febris 3 horas após a injeção. Estes dados, sugerem a ativação do sistema cininérgico durante o desencadeamento da resposta febril induzida pelo LPS.

Também foi observada a indução do RNAm para e receptores $B_{1}$ em hipotálamos dos animais 4 horas após a injeção iv de LPS $(5 \mu \mathrm{g} / \mathrm{Kg})$, fenômeno não observado em hipotálamo de animais que receberam injeção de solução salina estéril.

A administração icv de BK (5 a $20 \mathrm{nmol})$ em animais não tratados com captopril promoveu elevação transitória de temperatura corporal, enquanto que em animais tratados, a administração central de BK (5 e $10 \mathrm{nmol}$, icv) induziu uma elevação dose-dependente da temperatura corporal que se manteve durante todo o período de observação (6 horas). A injeção do agonista seletivo para receptores $\mathrm{B}_{1}$, des-Arg ${ }^{9}-\mathrm{BK}$ (DABK), em animais tratados com captopril não promoveu qualquer alteração da temperatura corporal dos animais. No entanto, a injeção de DABK $(10 \mathrm{nmol}, \mathrm{icv})$ 1,5 hora após uma dose sub-efetiva de IL-1ß (1ng, icv) promoveu significante aumento da temperatura corporal, sendo esta resposta reduzida pelo tratamento com DALBK (20 nmol, icv) ou celecoxib ( $5 \mathrm{mg} / \mathrm{kg}$, vo), inibidor seletivo da enzima cicloxigenase do tipo 2 .

Os tratamentos iv e icv com DALBK ou HOE140 reduziram de forma sigificativa a elevação de temperatura corporal induzida pela administração icv de BK (10 nmol) em animais pré-tratados com captopril. O tratamento com HOE-140 reduziu todo o curso da resposta, enquanto que o tratamento com DALBK reduziu somente a fase tardia (a partir da $3^{\mathrm{a}}$ hora) da elevação de temperatura corporal induzida pela BK. Estes resultados sugerem o envolvimento de ambos receptores no desenvolvimento da resposta febril induzida pela $\mathrm{BK}$.

O tratamento com HOE-149 ou DALBK ( $1 \mathrm{mg} /$ $\mathrm{Kg}$, iv) não modificou as respostas febris induzidas pela administração iv de IL-1ß $(2,5 \mu \mathrm{g} / \mathrm{Kg})$ e TNF- $\alpha(5 \mu \mathrm{g} /$ $\mathrm{Kg}$ ) ou icv de IL-1ß (3 ng), TNF- $\alpha$ (250 ng), IL-6 (500 ng), CRF (5 $\mu \mathrm{g}$ ) e PFPF (200 ng), sugerindo que entre os mediadores envolvidos na resposta febril, a $\mathrm{BK}$ agiria em um passo anterior à liberação das citocinas. A elevação da temperatura corporal induzida pela injeção de BK $(10 \mathrm{nmol}$, icv) foi inibida pelo tratamento com Il-1ra $(200 \mu \mathrm{g}$, icv) enquanto o tratamento com 
IL-ira $(200 \mu \mathrm{g}$, icv) enquanto o tratamento com sTNFr $(0,5 \mu \mathrm{g}, \mathrm{icv})$ reduziu somente a fase inicial e o tratamento com IL-6Ab (5 $\mu \mathrm{g}$, icv ) reduziu a fase final desta resposta. Alem disso, tanto o tratamento com o antagonista não seletivo para receptores de $\mathrm{CRF}, \mathrm{CRF}_{9-41}$ ( $25 \mu \mathrm{g}, \mathrm{icv})$, quanto o realizado com o antagonista seletivo para receptores CRF- $\mathrm{R}_{1}$, antalarmina $(20 \mathrm{mg} /$ $\mathrm{Kg}, \mathrm{sc}$ ), reduziram parcialmente a elevação da temperatura induzida pela injeção icv de BK. A administração icv de BK (10 nmol) em animais tratados com captopril induziu significante elevação dos níveis de $\mathrm{PGE}_{2}$ e $\mathrm{PGE}_{2 \alpha}$ no fluido cerebroespinal. Estes niveis foram reduzidos de forma significativa pelo tratamento dos animais com indometacina.

O tratamento com indometacina $(2 \mathrm{mg} / \mathrm{Kg}$, ip), dipirona $(120 \mathrm{mg} / \mathrm{Kg}$, ip), meloxicam $(10 \mathrm{mg} / \mathrm{Kg}$, vo) e celecoxib $(5 \mathrm{mg} / \mathrm{Kg})$ reduziu significativamente toda a resposta induzida pela injeção icv de BK, enquanto que o tratamento com dexametasona $(0,5 \mathrm{mg} / \mathrm{Kg}$, sc) reduziu a resposta a partir da $1^{\mathrm{a}}$ hora após a injeção de BK.

Em conjunto, estes dados colocam a BK como um mediador central da febre induzida pelo LPS, visto que esta cinina é capaz de promover a liberação de citocinas, PGS, e CRF.

\section{PARTICIPAÇÃO DO ÓXIDO NÍTRICO ESPINAL NA ANALGESIA INDUZIDA POR ESTIMULA- ÇÃO DE MECANISMOS DESCENDENTES DE CONTROLE DA DOR EM RATOS}

\section{Vania Aparecida Volpato Kina}

Orientador: Prof. Dr. William Alves do Prado

Dissertação de Mestrado apresentada em 14/11/2002

O envolvimento do óxido nítrico em processos nociceptivos tem sido extensivamente apontado na literatura. Os efeitos pró- ou antinociceptivos do NO, bem como de seus doadores e inibidores, apresentam resultados conflitantes dependendo das doses e dos modelos utilizados. Neste estudo, foram aferidos os limiares de resposta de ratos em modelo de dor persistente após lesão incisional na pata, submetidos ou não à lesão do funículo dorsolateral (FDL), área por onde trafegam vias descendentes de controle da dor. Os animais foram tratados com doador de NO (SIN-1) ou com inibidor de sua síntese (L-NOARG). As doses de SIN-1 utilizadas $(0.1,2.0,5.0,10.0,20.0 \mu \mathrm{g} / 10 \mu \mathrm{L})$ mostraram efeitos pro- ou anti-alodínicos de modo dose-dependente. A menor dose utilizada $0.1 \mu \mathrm{g}$ não teve efeito significante sobre a alodinia táctil incisional. As doses de 2.0 e $5.0 \mu \mathrm{g}$ de SIN-1 causaram antinocicepção em animais com ou sem lesão do FDL. Doses maiores de SIN-1 (10.0 e $20.0 \mu \mathrm{g} / 10 \mu \mathrm{L})$ exacerbaram a alodinia incisional em animais com ou sem lesão do FDL. As doses de L-NOARG utilizadas $(75,150 \mathrm{e}$ $300 \mu \mathrm{g} / 10 \mu \mathrm{L}$ ) reduziram a alodinia tactil incisional de animais com FDL íntegro, e não afetaram a alodinia em animais com FDL lesado. O SIN-1 $(5.0 \mu \mathrm{g} / 10 \mu \mathrm{L})$ facilitou a antinocicepcão causada pela estimulação elétrica do núcleo dorsal da rafe (NDR) e do núcleo prétectal anterior (NPAtA), enquanto que SIN-1 (20.0 $\mu \mathrm{g} / 10 \mu \mathrm{L}$ ) dificultou a antinocicepcão causada por tal estimulação. O L-NOARG não teve efeito sobre a antinocicepção causada pela estimulação elétrica do NDR e NptA. Estes resultados indicam a participação de modo dose-dependente do NO nos mecanismos de alodinia táctil incisional e de controle inibitório descentes.

\section{FISIOLOGIA}

\section{EFEITOS DA CASTRAÇÃO QUÍMICA E CASTRAÇÃo CIRÚRGICA NA CONCENTRAÇÃO DE HISTAMINA EM RATOS MACHOS PRÉ-PÚBERES E ADULTOS}

\section{Cleuzenir Toschi Gomes Barbieri}

Orientadora: Profa.Dra.Alzira A.M. Rosa e Silva

Dissertação de Mestrado apresentada em 12/07/2002

O papel do LH-RH na regulação da função tes- ticular tem sido intensamente estudado. Vários análogos superagonistas do LH-RH foram desenvolvidos. A administração crônica destes agonistas leva a inibição da função gonadal, resultando na chamada castração química. 
Os mastócitos têm sido estudados principalmente por seu envolvimento em reações alérgicas e inflamatórias. Estas células secretoras constituem a principal fonte de histamina. Dados da literatura mostram que análogos do LH-RH atuam sobre o mastócito causando sua desgranulação e, portanto a liberação de histamina. Além disso, os mastócitos são afetados pelos esteróides sexuais. Desse modo estudamos a interação entre LH-RH e a testosterona na concentração de histamina tecidual em animais pré-puberes e adultos. Nossos resultados mostram que a concentração de histamina intratesticular aumenta significativamente com a castração química, acompanhada de testosterona, nas duas idades. Nossos resultados mostram que a castração diminui a concentração de histamina no timo de animais pré-púberes, sendo que a administração da testosterona na castração química tem efeito estimulador, tendo efeito oposto na castração cirúrgica. Observamos que nem a castração química, nem a castração cirúrgica com ou sem reposição de testosterona, afetam a concentração de histamina no pulmão dos animais estudados. Os animais pré-púberes apresentam maiores níveis de histamina no pulmão, que os animais adultos. Estes resultados nos mostram a diversidade dos mastócitos, indicando que os mastócitos de diferentes tecidos podem responder de modo diferente aos mesmos fatores, e que diferentes fatores podem estar atuando nos mastócitos modulando a liberação de seus mediadores, nas diferentes fases do desenvolvimento.

\section{ESTEROIDOGÊNESE EM CÉLULAS DA GRANULOSA PRODUTORAS DE 17ß ESTRADIOL. EFEITOS DE ANGIOTENSINA II, ENDOTELINA-1 E PEPTÍDEO NATRIURÉTICO ATRIA}

\section{Luis Henrique Montrezor}

Orientadora: Profa.Dra. Alzira A. M. Rosa e Silva

Tese de Doutorado apresentada em 16/07/2002

Com o intuito de esclarecer as interações entre gonadotrofinas, esteróides ovarianos e fatores de crescimento sobre as funções foliculares, tem-se buscado padronizar modelos experimentais que mimetizem a fisiologia ovariana. O presente trabalho utiliza modelo de cultura de células da granulosa bovinas, em meio quimicamente definido, para estudar os efeitos da Angiotensina-II (A-II), Endotelina-1 (ET-1) e Peptídeo Natriurético Atrial (ANP) sobre a esteroidogênese e crescimento folicular. Na primeira etapa dos experimentos, para a padronização da cultura, ovários foram obtidos em matadouros e transportados até o laboratório em solução salina a $37^{\circ} \mathrm{C}$. Pequenos folículos (3-5 mm de diâmetro) foram selecionados de acordo com a vascularização e coloração do fluido folicular; abertos e lavados com meio de cultura. $\mathrm{O}$ meio foi composto por alfa-MEM, bicarbonato de sódio, Hepes, transferrina, antibióticos, selenito de sódio, aminoácidos não essenciais, androstenediona, insulina, fator de crescimento semelhante a insulina (IGF-1), polivinil álcool (PVA) ou albumina sérica bovina (BSA). Para estudar a esteroidogênese, 500.000 células foram incubadas com $1 \mathrm{ml}$ de meio de cultura e para os estudos da proliferação celular 200.000 células foram incubadas com timidina triciada em $250 \mu 1$ de meio. As celulas foram mantidas em estuda a $37,5^{\circ} \mathrm{C}$ com $5 \%$ de $\mathrm{CO}_{2}$ durante $144 \mathrm{~h}$, com trocas de $70 \%$ do meio a cada $48 \mathrm{~h}$. $\mathrm{O}$ meio coletado foi congelado a $-20^{\circ} \mathrm{C}$ para posteriores análises hormonais. No final dos 6 dias de cultura as placas foram congeladas a $-20^{\circ} \mathrm{C}$ para análises das concentrações de timidina. Os resultados mostram que as células da granulosa cultivadas com PVA e BSA são viáveis mantendo produção de $\mathrm{E}_{2}$ durante os 6 dias. A produção de $\mathrm{P} 4$ também foi mantida constante, sendo maior no meio com BSA. A correlação $\mathrm{E}_{2}: \mathrm{P}_{4}$ é crescente até 96 (PVA) e 144 (BSA). O crescimento celular, analisado pela incorporação de timidina foi significativo para PVA e BSA no tempo $144 \mathrm{~h}$. Os resultados morfológicos indicam que as CG mantidas nesse modelo, condizem com células foliculares funcionalmente ativas in vivo. Numa segunda etapa, observamos os efeitos pró dominância e/ou pró atresia da All, ET-1 e ANP sobre a esteroidogênese e o crescimento das CG mantidas em cultura durante 96 horas na presença de PVA. Aproximadamente 500.000 células viáveis foram incubadas em placas de 24 fossas com $1 \mathrm{ml}$ de meio, na ausências e presença de diferentes concentrações $\left(10^{-12}, 10^{-10}\right.$, $10^{-9}, 10^{-8}$ e $\left.10^{-7} \mathrm{M}\right)$ de All, ET-1 e ANP. Os meios coletados foram estocados a $-20^{\circ} \mathrm{C}$ para posteriores análises das produções médias de pregnenolona, progesterona e estradiol, assim como do consumo de androstenediona. Os resultados mostram que os peptídeos estudados participam ativamente nos processos esteroidogênicos, assim como durante a proliferação celular, dependentes da dose e do tempo da cultura. Portanto, esses fatores de crescimento podem atuar em momentos cruciais na vida folicular (durante o desvio), onde um folículo surge como dominante na onda com capacidade ovulatória. 


\section{CONTROLE NEUROQUÍMICO DO “SET POINT” TERMORREGULATÓRIO}

\section{Alexandre Alarcon Steiner}

Orientador: Prof. Dr. Luiz G. de Siqueira Branco

Tese de Doutorado apresentada em 01/08/2002

Objetivos: Sabe-se que a temperatura corporal (Tc) é regulada ao redor de um "set point" termorregulatório, o qual tem a área pré-óptica (POA) como uma importante estrutura de controle. Diversos estímulos são capazes de alterar o "set point" termorregulatório. Dentre estes, estímulos infecciosos e inflamatórios elevam o "set point" termorregulatório, causando uma elevação na Tc, a qual é denominada febre. Por outro lado, em situações em que o aporte de oxigênio para os tecidos encontra-se prejudicado há uma queda no "set point" termorregulatório, culminando em uma redução na Tc, uma resposta que vem sendo denominada anapirexia. A febre e a anapirexia parecem ser respostas benéficas sob as condições em que são induzidas. Nesse sentido, a febre aumenta a efetividade do sistema imune e inibe o crescimento da maioria dos microorganismos patogênicos, enquanto que a anapirexia reduz o consumo de oxigênio e o estresse oxidativo em condições de hipóxia. Entretanto, os mecanismos intracelulares que ocorrem na POA para gerar febre e anapirexia são praticamente desconhecidos. Uma vez que o AMP cíclico (cAMP) e o GMP cíclico (cGMP) parecem agir na POA reduzindo a Tc, o objetivo do presente estudo foi testar a hipótese de que uma redução na produção intracelular de cAMP e cGMP na POA medeia a febre, enquanto que um aumento na geração destes nucleotídeos cíclicos na POA medeia a anapirexia.

Métodos: Mediu-se a Tc de ratos Wistar machos por biotelemetria ou por sonda colônica antes e após o tratamento com diversos agentes farmacológicos. Também fez-se um estudo imunocitoquímico da localização do cAMP e do cGMP na POA e dosou-se o conteúdo de cAMP e cGMP na região anteroventral ao terceiro ventrículo (AV3V), onde a POA encontrase localizada.

Resultados principais: Primeiramente, através de imunocitoquímica, observou-se que a POA contém uma grande quantidade de neurônios produtores de cAMP e cGMP. Em nossos experimentos, a administração intra-POA de agonistas do cAMP e do cGMP produziu uma queda na Tc de cerca de $1^{\circ} \mathrm{C}$. De forma interessante, houve uma queda no contéudo de cAMP na AV3V durante a febre induzida por $\mathrm{PGE}_{2}$ e uma redução no contéudo de cGMP durante a febre induzida por endotoxina. Por outro lado, durante a anapirexia induzida por hipóxia, houve uma elevação no conteúdo de cAMP e cGMP na POA. Visando-se testar diretamente a hipótese de que uma redução no cAMP e no cGMP na POA medeia a febre, verificou-se o efeito do Rp-cAMPS ( $1 \mu \mathrm{g})$ e do Rp-cGMPS $(1 \mu \mathrm{g})$, os quais sao inibidores das proteínas quinases dependentes de cAMP e de cGMP, respectivamente, sobre a Tc. Como resultado, notou-se que a microinjeção concomitante de Rp-cAMPS e Rp-cGAMPS, mimetizando assim uma queda concomitante na produção de cAMP e cGMP na POA, induziu febre nos animais experimentais. Em relação à anapirexia, observou-se que a microinjeção de Rp-cAMPS e RpcGMPS na POA atenuou a anapirexia induzida por hipóxia.

Conclusão: Com base nesses dados, o presente estudo demonstra um importante papel do cAMP e do cGMP, agindo na POA, na modulação do "set point" termorregulatório, com uma queda nesses nucleotídeos gerando febre e uma elevação nos mesmos produzindo anapirexia. Certamente, o conhecimento dos mecanismos neuroquímicos envolvidos na geração de febre e anapirexia podem gerar melhores estratégias para se controlar a Tc em condições de infecção e hipóxia.

\section{CARACTERIZAÇÃO DA FEBRE COMPORTAMENTAL INDUZIDA POR LPS EM SAPOS}

\section{Kênia Cardoso Bícego Nahas}

Orientador: Prof. Dr. Luiz G. de Siqueira Branco

Tese de Doutorado apresentada em 02/08/2002

A febre é definida como um aumento regulado da temperatura corporal (Tc), ou seja, um aumento do “set point" termorregulatório. Lipopolissacarídeo (LPS) é um componente da parede celular de bactérias Gramnegativas que é bastante utilizado para induzir febre em animais experimentais. Em mamíferos, considerase que este agente ative uma cascata de eventos que culminem na alteração da atividade de neurônios da área preóptica (POA) no sistema nervoso central para 
induzir uma elevação na TC. Salvo algumas exceções, a prostaglandina $\mathrm{E}_{2}$ é considerada o mediador mais proximal da febre agindo na POA para aumentar o "set point" termorregulatório. Além dos agentes pirogênicos, que induzem a febre, existem também os agentes antipiréticos, que inibem a sua manifestação, dentre os quais um dos mais estudados em mamíferos é a arginina vasopressina (AVP). Anfíbios anuros, sendo animais ectotérmicos, regulam sua temperatura corporal primariamente pelo comportamento, característica que tem sido relacionada diretamente com alterações do "set point" termorregulatório. Portanto, estes animais constituem modelos experimentais interessantes para o estudo da termorregulação e da febre em vertebrados. Porém, os mecanismos envolvidos na febre comportamental em sapos permanece pouco estudado. Neste trabalho foi testada a hipótese que a via das prostaglandinas e a POA são importantes para o desenvolvimento da febre comportamental induzida por LPS e que a arginina vasotocina (AVT - análogo da
AVP em vertebrados não mamíferos) age como antipirético em sapos Bufo paracnemis. As medidas de temperatura de preferência dos animais foram realizadas utilizando-se uma câmara de gradiente térmico. LPS induziu febre nas doses de 0,2 e 2 $\mathrm{mg} / \mathrm{kg}$ mas não nas doses de 0,002 e $0,02 \mathrm{mg} / \mathrm{kg}$. O pré-tratamento sistêmico com indometacina $(5 \mathrm{mg} /$ $\mathrm{kg}$ ), um inibidor da enzima ciclooxigenase, responsável pela síntese de PG, inibiu a febre induzida por LPS. Os sapos cuja POA foi lesada também não desenvolveram febre quando injetados com LPS. Em relação à AVT, este agente inibiu a febre induzida por LPS na dose de $300 \mathrm{pmol} / \mathrm{kg}$ quando injetado perifericamente e na dose de $10 \mathrm{pmol} / \mathrm{kg}$ quando injetado intracerebroventricularmente. Estes resultados vão de encontro à hipótese inicial e indicam que os mecanismos envolvidos na febre testados acima apresentam uma história filogenética antiga entre os vertebrados e ocorrem por alteração do "set point" termorregulatório.

\section{MECANISMOS DA REDUÇÃO DA LIPÓLISE NO TECIDO ADIPOSO DE RATOS ADAPTA- DOS À DIETA HIPERPROTÉICA, LIVRE DE CARBOIDRATOS}

\section{Maristela Polachini Martins Afférri}

Orientador: Prof. Dr. Renato Helios Migliorini

Tese de Doutorado apresentada em 16/08/2002

Estudos anteriores do laboratório mostraram que ratos adaptados à uma dieta hiperprotéica, livre de carboidratos (HP), apresentam reduzida taxa de lipólise, evidenciada por baixos níveis de ácidos graxos livres (AGL) plasmáticos e por reduzidas taxas de glicerol liberado em incubações com fragmentos de tecido adiposo ou adipócitos isolados. Para obter maiores informações sobre o mecanismo dessa redução foram investigados, no presente trabalho, os efeitos da dieta HP nos processos neurais de controle da lipólise e na atividade lipolítica dos adipócitos.

Os ratos foram adaptados por 15 dias a uma dieta hiperprotéica (w/w, 70\% de proteínas, $8 \%$ de gorduras, livre de carboidratos) ou a uma dieta controle $(16 \%$ de proteínas, $66 \%$ de carboidratos, e $8 \%$ de gorduras) antes dos experimentos, os quais foram realizados no estado alimentado.

Os resultados obtidos podem ser resumidos como a seguir:

A adaptação à dieta HP não afetou significativamente nem a hiperglicemia, nem o aumento das concentrações plasmáticas de glicerol e AGL induzidos pela neurocitoglicopenia central, provocada pela infusão intracerebro-ventricular de 2-deoxi-d-glicose (10mg:30 $\mu \mathrm{L}$, por $20 \mathrm{~min}$ ).

A concentração de noradrenalina ou as atividades neuronais dos neutrotransmissores (dopamina e serotonina) no VMH e LH não diferiram significativamente em ratos alimentados HP e controles.

Em concordância com estudos prévios in vivo e em fragmentos do tecido adiposo ou adipócitos in vitro, atividade lipolítica do tecido adiposo perfundido in situ, encontrava-se reduzida em ratos adaptados a dieta HP, como mostrado por concentrações diminuídas de glicerol no dialisado.

Confirmado observações anteriores, a taxa de lipólise basal (não estimulada), estimada pela liberação de glicerol para o meio de incubação, encontravase reduzida em adipócitos de ratos alimentados com dieta HP. A resposta lipolítica à agonistas adrenérgicos não-seletivos (noradrenalina, adrenalina, isoproterenol e fenilefrina ) e seletivos (dobutamina, clembuterol, CL316,243 e BRL 37,344) estava reduzida em aproximadamente $40 \%$, em adipócitos de ratos HP. Entretanto, a composição de adrenoceptores, a julgar pela potência relativa dos diferentes agonistas, era similar à de adipócitos de ratos controles.

A inibição, por um antagonista específico $\beta_{3}$, SR 
59,230 , do aumento da lipólise induzida pela noradrenalina ou pelo CL 316,243 foi mais acentuada em adipócitos de ratos HP quando calculada como porcentagem das taxas na ausência do antagonista, mas não diferiu significativamente nos dois grupos experimentais, em termos absolutos.

A resposta lipolítica a agentes lipolíticos que atuam intracelularmente (dibutiril AMPc - DBcAMP, forskolina - FSK ou isobutilmetilxantina - IBMX) encontrava-se reduzida em adipócitos de ratos HP. A estimulação da lipólise pelo DBcAMP e FSK estava reduzida em aproximadamente $45 \%$ em adipócitos de ratos HP, uma redução similar à obtida em experimentos com os agonistas adrenérgicos. A redução da estimulação da lipólise por IBMX em adipócitos HP, foi menor (29\%).

A adição de adenosina deaminase (ADA) ao meio de incubação resultou em um aumento quantitativamente similar na atividade lipolítica de adipócitos de ratos HP e controles. A adição de ADA e IBMX induziu um aumento na lipólise similar ao induzido pelo DBcAMP isoladamente em adipócitos de ratos HP, mas não em adipócitos controles, nos quais o aumento induzido pelas duas drogas juntas foi menor do que aquele produzido pelo DBcAMP.

A adaptação à dieta HP não afetou o contéudo da proteína lipase hormônio sensível (HSL) nos adipócitos,mas induziu uma redução de $17 \%$ na atividade da enzima.
Analisados em conjunto os dados acima permitem as seguintes inferências:

A reduzida atividade lipolítica em ratos adaptados a dieta HP não parece ser devido a uma incapacidade do sistema nervoso central de responder a sinais estimuladores da lipólise ou a mudanças na concentração de neurotransmissores centrais envolvidos na ativação simpática.

A principal razão para a reduzida lipólise basal (não estimulada) em adipócitos de ratos HP parece ser uma modificação no processo intracelular de ativação da lipólise com uma menor proporção da lipase hormônio sensível na sua forma fosforilada (ativa). Tendo em vista estudos recentes da literatura, demonstrando que os mesmos agentes lipolíticos usados no presente trabalho aumentam a lipólise em adipócitos sem alterar o contéudo ou a atividade da HSL, a reduzida resposta dos adipócitos HP aos agentes lipolíticos provavelmente resultou de uma deficiência dos processos intracelulares de ativação da lipólise, que não dependem da fosforilação da HSL. Não é possível descartar a hipótese de que a dieta HP não afeta a função ou a atividade dos adrenoceptores da membrana do adipócito.

Outros estudos são necessários para esclarecer o motivo das alterações na atividade lipolítica dos adipócitos induzidas pela dieta HP. A hipótese é proposta de que elas sejam devidas a uma redução mantida da atividade simpática do tecido adiposo.

\section{VARIABILIDADE DA PRESSÃO ARTERIAL, RESPOSTA PRESSORA Á TIRAMINA E FRE- QÜÊNCIA INTRÍNSECA DE MARCAPASSO CARDÍACO DE RATOS ACORDADOS COM DIA- BETE EXPERIMENTAL. EFEITO DA INSULINA}

\section{Lys Angela Favaroni Mendes}

Orientador: Prof. Dr. Hélio Cesar Salgado

Dissertação de Mestrado apresentada em 23/08/2002

Os objetivos deste trabalho foram avaliar em ratos não anestesiados com diabete crônico (12-16 semanas), tratados, ou não, com insulina, a variabilidade da pressão arterial, a resposta pressórica à administração de tiramina e a freqüência intrínseca de marcapasso cardíaco.

$\mathrm{O}$ diabete induzido por meio da administração de estreptozotocina (45-60 mg/Kg i.v.). Parte destes animais passou a receber tratamento insulínico (9 UI), diário, até o dia do experimento.

$\mathrm{Na}$ véspera do experimento, os animais foram submetidos à cirurgia para a implantação de cânulas, na artéria e e veia femorais, para registro da pressão arteria pulsátil e administração de drogas, respectivamente.

Os animais diabéticos apresentaram hiperglicemia ( $353 \pm 4,3 \mathrm{mg} / \mathrm{dl})$, perda de massa crporal, e tendência à hipotensão $(98 \pm 2,4 \mathrm{mmHg})$ e bradicardia (302 $\pm 6,1 \mathrm{bpm})$. O exame da variabilidade da pressão arterial no domínio da freqüência, por meio da análise espectral (análise autorregressiva), mostrou que houve, nos animais diabéticos, uma diminuição no componente de baixa freqüência, o qual compreende a faixa de 0,2 a $0,75 \mathrm{~Hz}$. A atenuação da resposta pressora à administração de tiramina $(23 \pm 1,0 \mathrm{mmHg})$ e a redução da variabilidade da pressão arterial sugerem um 
comprometimento autonômico simpático vascular. Além disso, estes animais apresentaram uma diminuição na frequiência intrínseca de marcapasso cardíaco (313 $\pm 5,9 \mathrm{bpm})$, indicando que o nodo SA também foi afetado pelo diabete.

A terapia insulínica não só revelou o quadro hiperglicêmio ( $110 \pm 3,7 \mathrm{mg} / \mathrm{dL})$, como também preveniu as alterações de perda de massa corporal presente no diabete crônico experimental. Os valores de pressão arterial $(105 \pm 1,7 \mathrm{mmHg})$ e de frequiência cardíaca basal $(309 \pm 8,0 \mathrm{bpm})$ dos animais tratados com insulina estavam mais próximos dos valores observados nos animais controles $(104 \pm 2,9 \mathrm{mmHg}$ e $321 \pm 8,3 \mathrm{bpm}$, respectivamente). Entretanto, a atenuação da resposta pressora à tiramina $(29 \pm 1,7 \mathrm{mmHg})$ nos animais tratados sugere alteração nas terminações simpáticas e/ou alteração na responsividade da musculatura lisa vascular a determinados estímulos vasopressores.

Em síntese, o diabete provocou alterações autonômicas cardiovasculares e, também, alteração do nodo SA, enquanto que o tratamento insulínico preveniu a maioria destas alterações, exceto as secundárias, nas terminações simpáticas e/ou musculatura lisa vascular.

\section{PARTICIPAÇÃO DO MESENCEFÁLO DE ANFÍBIOS ANUROS NO CONTROLE DA VENTILAÇÃO}

\section{Luciane Helena Gargaglioni Batalhão}

Orientador: Prof. Dr. Luiz G. de Siqueira Branco

Tese de Doutorado apresentada em 13/09/2002

Apesar dos recentes avanços na fisiologia comparativa, os mecanismos envolvendo o controle respiratório de anfíbios estão longe de serem entendidos, principalmente o papel de áreas prosencefálicas no controle respiratório. Portanto, o presente estudo investigou o papel do mesencéfalo de anuros na modulação da ventilação, utilizando a estimulação elétrica para identificar sítios capazes de estimular e inibir a ventilação. Também exploramos o papel de uma estrutura mesencefálica específica, o núcleo do istmo, na modulação do padrão episódico e no controle cardiorespiratório durante a hipóxia e a hipercarbia e dois dos prováveis mediadores desta resposta (glutamato e óxido nítrico).

Nos experimentos de estimulação elétrica a ventilação fictícia foi medida a partir do ramo mandibular do nervo trigêmio e do ramo laringeal do nervo vago, utilizando a preparação in situ. Os resultados dos experimentos com estimulação indicam que informações provenientes de áreas mesencefálicas envolvidas na integração visual e auditiva, funções motoras e no alerta comportamental também modulam a respiração. Os efeitos destes sítios podem ser tanto inibitórios como excitatórios e são primariamente na frequiência das oscilzações bucais e na ventilação pulmonar.

Nos experimentos envolvendo o núcleo do istmo foi utilizado o método de pneumotacografia para medida de ventilação. Nossos resultados também mostram que o núcleo do istmo não participa do controle ventilatório durante situações de normóxia normocárbica, mas exercem um papel inibitório sobre a hiperventilação induzida pela hipoxia e hipercarbia, atuando principalmente no volume corrente. Os prováveis mediadores desta resposta são o glutamato e o NO, uma vez que a microinjeção do ácido kinurênco (antagonista de receptores ionotrópicos NMDA e não NMDA) e de L-NAME (inibidor não seletivo da enzima NOS) promoveu um aumento das respostas ventilatórias à hipoxia e à hipercarbia.

Com base nos dados do presente estudo, verificamos que o núcleo do istmo não participa do controle da pressão e da frequiência cardíaca em Bufo paracnemis.

\section{ATIVIDADES DE FRAÇÕES E TOXINAS PURIFICADAS DO VENENO DO ESCORPIÃO BRA- SILEIRO TITYUS SERRULATUS EM CANAIS PARA POTÁSSIO}

\section{Aldo Rogelis Aquiles Rodrigues}

Orientador: Prof. Dr. Wamberto Antonio Varanda

Tese de Doutorado apresentada em 09/10/2002

Inicialmente, analisou-se o veneno d escorpião brasileiro Tityus serrulatus quanto à presença de to- xinas que interagem com canais para potássio de baixa $\left(\mathrm{SK}_{\mathrm{Ca}}\right)$ e de alta $\left(\mathrm{BK}_{\mathrm{Ca}}\right)$ condutância ativados por cálcio e com os controlados pela voltagem $(\mathrm{Kv})$, em estudos de ligação. A Apamina $\left(\mathrm{SK}_{\mathrm{Ca}}\right)$, a Iberiotoxina $\left(\mathrm{BK}_{\mathrm{Ca}}\right)$ e a Hongotoxina ${ }_{1}(\mathrm{Kv})$ marcadas radioativamente $\left({ }^{125} \mathrm{I}\right)$ foram utilizadas e a capacidade de algu- 
mas frações purificadas desse veneno, em deslocar a ligação destes radioligantes de seus sítios receptores em membrana sináptica de cérebro de rato, avaliada. Hongotoxina, ${ }_{1}$ um bloqueador de alta afinidade para canais Kv pertencentes à subfamília Shaker, mais precisamente dos membros Kv1.1, 1.2 e 1.3 e apresentando baixa afinidade para os canais Kv1.6, foi o radioligante mais deslocado por uma das frações. Um polipeptídeo presente nesta fração e identificado como sendo a Tityustoxina-K $\alpha$ mostrou-se o componente mais ativo em deslocar este radioligante. Esta toxina, purificada previamente, e conhecida por sua ação principalmente em correntes nativas do tipo retificadora retardada (ou tardia) que não se inativam, embora sua ação sobre um componente inativante em neurônios do gânglio da raiz dorsal foi também descrita. Adicionalmente esta toxina é considerada como um bloqueador seletivo de canais clonados do tipo Shaker Kv1.2. Avaliou-se, no presente trabalho, a possível interação da TsTX-K $\alpha$ sobre os canais Kv1.3, um outro membro da subfamilia Shaker de canais $\mathrm{K}^{+}$, utili- zando-se da técnica de voltage-clamp. A TsTX-K $\alpha$ bloqueia os canais Kv1.3 expressos em oócitos de Xenopus laevis com uma alta afinidade. Este bloqueio foi dependente do $\mathrm{pH}$ externo $\left(\mathrm{K}_{\mathrm{D}}\right.$ de 3,93 ( $\left.\mathrm{pH} 7.5\right)$, 9,48 (pH7.0) e 94,48 nM (pH 6.5) e completamente reversível. A TsTX-K $\alpha$ não afetou a dependência de voltagem da ativação ou da inativação dos canais Kv1.3. Algumas propriedades do bloqueio dos canais Kv1.3 pela TsTX-K $\alpha$ foram também analisadas pela técnica de patch-clamp em uma linhagem de células de mamíferos (L929), transformada para a expressão estável destes canais. Neste sistema o $\mathrm{K}_{\mathrm{D}}$ medido foi de 19,8 nM no pH 7,4 e a TsTX-K $\alpha$ nao alterou as constantes de tempo de ativação, desativação e da inativação dos canais Kv1.3. Assim, toxina parece atuar como um bloqueador simples destes canais. Em conclusão, os resultados sugerem que a TsTX-K $\alpha$ é uma ferramenta útil para avaliar não apenas as funções dos canais Kv1.2, como previamente aceito na literatura, mas também dos canais Kv1.3.

\section{PARTICIPAÇÃO DO ÓXIDO NÍTRICO E MONÓXIDO DE CARBONO NA TERMORREGULA- ÇÃO: ANAPIREXIA E FEBRE}

\section{Maria Camila Almeida}

Orientador: Prof. Dr. Luiz G. de Siqueira Branco

Dissertação de Mestrado apresentada em 20/10/2002

A anapirexia é uma queda regulada da temperatura corporal interna $(\mathrm{Tc})$. Vários estímulos são capazes de induzir anapirexia como hipóxia, anemia, 2DG e insulina. A ocorrência de anapirexia em resposta à insulina já foi descrita há 60 anos. Por outro lado, a febre é um aumento regulado da Tc, e faz parte de uma resposta complexa do hospedeiro à infecção ou inflamação sistêmica. $\mathrm{O}$ fator de crescimento derivado de plaquetas (PDGF) é uma proteína que exerce importantes funções no sistema nervoso central (SNC). Recentemente foi demonstrado que o PDGF induz resposta febril quando injetado intracerebroventricularmente e que o mesmo pode agir como um pirogênio endógeno no SNC.

Os neuromoduladores gasosos óxido nítrico (NO) e monóxido de carbono (CO) exercem ações termorregulatórias e tem sido demonstrado que os mesmos participam tanto da febre quanto da anapirexia. A produção de NO é catalisada pela enzima NO sintase (NOS) durante a conversão do aminoácido Larginina para L-citrulina, enquanto que a enzima heme oxigenase (HO) catalisa o metabolismo de heme para biliveredina, ferro livre e $\mathrm{CO}$.

O primeiro objetivo do presente estudo foi verificar a hipótese que o $\mathrm{NO}$ e o $\mathrm{CO}$ participam da anapirexia induzida por insulina e que o $\mathrm{CO}$, ao invés da biliverdina ou ferro, é o subproduto da $\mathrm{HO}$ envolvido nesta resposta. A Tc dos ratos foi então medida durante a infusão intravenosa (i.v.) de insulina ( 0,2 e $2 \mathrm{U}$ $\left.\mathrm{kg}_{-}{ }^{1} \mathrm{~h}^{-1}\right)$, combinada com diferentes tratamentos intracerebroventriculares (i.c.v.). Foi observada queda significativa da Tc após infusão de insulina. O tratamento com $\mathrm{N}^{\mathrm{G}}$ - nitro- ${ }_{\mathrm{L}}$-arginina metil ester (L-

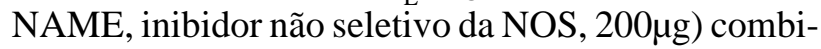
nado com a infusão de salina não causou alterações significativas da TC. Quando os dois tratamentos foram combinados, a queda na Tc induzida por insulina foi abolida. O tratamento i.c.v. com zinco deuteroporfirina 2,4-bis glicol (ZnDPBG, inibidor da HO, 200nmol) não causou mudanças significativas na Tc quando combinado com a infusão de salina mas aumentou significativamente a anapirexia induzida por insulina. Os tratamentos com o quelante de ferro deferoxamina (250 
$\mu \mathrm{g})$ e biliverdina (152nmol) nao alteraram a anapirexia induzida por insulina, enquanto que o tratamento com salina saturada com $\mathrm{CO}$ reduziu a queda na $\mathrm{Tc}$ induzida por insulina. Esses resultados indicam que o NO, participa da geração da anapirexia induzida por insulina enquanto que a via da $\mathrm{HO} / \mathrm{CO}$ possui a função de prevenir quedas excessivas da TC durante a anapirexia induzida por insulina. Uma vez que os tratamentos com biliverdina e ferro não tiveram efeito, enquanto que o $\mathrm{CO}$ reduziu significativamente a queda na Tc induzida por insulina, podemos inferir que o $\mathrm{CO}$ é o subproduto da $\mathrm{HO}$ envolvido nesta resposta.

Por fim, nós investigamos a participação do NO e Co na febre induzida por PDGF. A injeção i.c.v. de PDGF-BB produziu um aumento na Tc dependente da dose. A febre induzida por PDGF-BB (10ng) foi exacerbada pelo tratamento com L-NAME $(200 \mu \mathrm{g})$ e Smetil-L-tiocitrulina (SMTC 2,5 $\mu \mathrm{mol}$ - inibidor seletivo

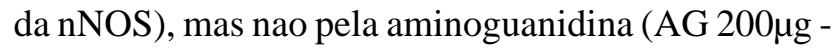
inibidor seletivo da iNOS). O tratamento com ZnDPBG (200nmol) não afetou a febre induzida por PDGF. Esses dados indicam que o NO participa da febre induzida por PDGF e que a nNOS é a isoforma da NOS responsável pela síntese de NO nesta resposta. Além disso nossos dados sugerem que a vida da $\mathrm{HO} / \mathrm{CO}$ não está envolvida na febre por PDGF.

\section{IMUNOLOGIA BÁSICA E APLICADA}

\section{FREQÜÊNCIA DE CORONAVÍRUS E RINOVÍRUS COMO CAUSA DE INFECÇÕES RESPIRA- TÓRIAS AGUDAS EM CRIANÇAS}

\section{Izolete Santos Macedo}

Orientador: Prof. Dr. Eurico de Arruda Neto

Dissertação de Mestrado apresentada em 15/07/2002

Coronavírus humanos ( $\mathrm{HCoV})$ e rinovírus (HRV) são importantes causas de infecções respiratórias agudas (IRA) no mundo. A maioria das infecções causadas por estes agentes são resfriados comuns, mas complicações como sinusite, otite média e ataques de asma são frequientes. Há poucos estudos sobre o impacto de HCoV e HRV no Brasil. Nós desenvolvemos um ensaio baseado em RT-PCR e hibridização para $\mathrm{HCoV}$ e temos usado este ensaio juntamente com um ensaio de RT-PCR previamente descrito para avaliar as frequiências de $\mathrm{HCoV}$ e HRV em crianças com ARI. Estes ensaios foram testados em quatro grupos clínicos diferentes no Brasil: 1- crianças menores de 2 anos de idade seguidas prospectivamente em creche para crianças carentes em Salvador, Bahia; 2- crianças menores de 12 anos de idade que procuraram cuidados médicos na unidade de emergência (UE) do Hospital das Clínicas da Faculdade de Medicina de Ribeirão Preto - USP, com chiado; 3- crianças menores de 5 anos de idade com
AIDS e IRA baixa admitidas na enfermaria da pediatria do Hospital das Clínicas da Faculdade de Medicina de Ribeirão Preto - USP e 4- crianças menores de 12 meses de idade admitidas em centro de terapia intensiva (UTI) por IRA baixa em hospital da comunidade (Hospital Santa Lydia) em Ribeirão Preto.

Nós encontramos 73/286 (25,5\%) lavados nasais (LN) positivos para HRV e 18/286 (6,3\%) para $\mathrm{HCoV}$ nas crianças da creche em Salvador, Bahia; 26/ 118 (22\%) LN positivos para HRV e 3/118 (2,5\%) para $\mathrm{HCoV}$ em crianças com chiado atendidas na UE; 16/73 (22\%) LN positivas para HRV e nenhuma para HCoV em crianças com AIDS e IRA baixa; 5/31 (16\%) LN positivos para HRV e nenhuma para $\mathrm{HCoV}$ em crianças na UTI com IRA baixa. Interessantemente, não há diferença estatisticamente significante na detecção das frequiências de HRV entre crianças com chiado e controles sem sintomas de IRA, das quais 9/ $46(19 \%)$ foram positivas para HRV.

HRV foi um freqüente agente de IRA em crianças em diversos grupos clínicos no Brasil, principalmente entre as crianças da creche da cidade litorânea tropical onde as condições ambientais são mais propícias à transmissão. Diferentemente de estudos feitos no hemisfério norte, nós não encontramos associação 
significante de rinovírus com chiado. Consideravelmente, $19 \%$ de 46 crianças vistas na EU por outros motivos que não IRA tiveram HRV detectável seus LN. Apesar de detectado com freqüência baixa em geral, $\mathrm{HCoV}$ tende a ser mais freqüente nas crianças da creche. Entretanto, HCoV não foi encontrado em nenhuma criança com IRA baixa, com ou sem AIDS.

Até onde sabemos, esta é a primeira vez que um estudo sobre freqüência de dois dos mais importantes agentes de resfriado comum baseado em RTPCR foi conduzido no Brasil, e a primeira vez que $\mathrm{HCoV}$ foi detectado em nosso país. Os dados sugerem que HRV e HCoV não são significantemente associados com chiado e que a freqüência de $\mathrm{HCoV}$ como causa da IRA no Brasil é similar aquela encontrada em regiões temperadas no mundo.

\section{SEQUENCIAMENTO NUCLEOTÍDICO COMPLETO E ESTUDOS ASSOCIADOS AO GENOMA DO BUNYAVIRUS OROPOUCHE}

\section{Victor Hugo Aquino Quintana}

Orientador: Prof. Dr. Luiz Tadeu Moraes Figueiredo

Tese de Doutorado apresentada em 17/07/2002

O vírus Oropouche (ORO) que pertence ao gênero Bunyavirus da família Bunyaviridae, é o agente causador da febre do Oropouche, a segunda arbovirose em número de casos humanos no Brasil. A importância desta virose levou-nos a determinar, de forma inédita, a sequiência completa dos segmentos de RNA L, M e S de ORO cepa BeAn1991. Para obtenção individual de cada um dos três segmentos de RNA, desenvolvemos método simples que incluia precipitação das partículas virais, purificação do RNA e eletroforese deste em gel de agarose a partir do qual os segmentos de RNA foram recuperados. O segmento S de ORO foi amplificado por RT-PCR utilizando primer único desenhado com base na seqüência 3' do segmento $S$ do vírus Bunyamwera (protótipo do gênero). O seqüenciamento mostrou um segmento $\mathrm{S}$ com 754 nucleotídeos tendo duas regiões codificantes (ORF) sobrepostas no sentido complementar, as quais codificam a proteína $\mathrm{N}$ com 231 aminoácidos e a proteína NSs com 91 aminoácidos. Também, possui duas regiões não codificantes, uma na extremidade 5' (RNC5') de 44 nucleotídios e outra na extremidade 3' (RNC3') de 17 nucleotídios. Para seqüenciamento o segmento M utilizamos um método de genomic walking em duas etapas: amplificação linear (AL) seguida de uma PCR com primer único (PCR-PU). O segmento $\mathrm{M}$ possui 4385 nucleotídios com uma ORF no sentido complementar flanqueada por uma RNC5' de 31 nucleotídios e RNC3' de 94 nucleotídios. A ORF codifica a poliproteína de 1420 aminoácidos que, após clivagem, gera as glicoproteínas G1 e G2, e a proteína NSm. O método de Genomic walking em duas etapas mostrou-se adequada no caso do segmento $\mathrm{M}$ de
ORO e poderia ser usado na obtenção de seqüências desconhecidas de DNA adjacentes a regiões curtas e conhecidas de vírus com genômas mais complexos conforme confirmamos ao testá-la para citomegalovirus. A seqüência do segmento L de ORO foi obtida processando cDNAs sobrepostos. Esta possui 6846 nucleotídios com uma ORF no sentido complementar que codifica a proteína L de 2250 aminoácidos. A ORF está flanquada de uma RNC5' de 43 nucleotídios e de uma RNC2' de 53 nucleotídios. A seqüência de aminoácidos da proteína L de ORO foi alinhada com a de outros vírus da família Bunyaviridae, bem como com a proteína PB1 do vírus influenza. PB1 possui 4 sítios ativos descritos: os sítios de ligação às extremidades 5' e 3' do RNA viral (5' vRNA e 31 vRNA), o de atividade endonuclease para a produção de capprimer, e o de catálise para adição de nucleotídios. $\mathrm{O}$ alinhamento mostrou que a proteína $\mathrm{L}$ de ORO possui as três regiões características da RNA polimerase dos vírus de polaridade negativa, e também uma quarta região conservada. Também, o alinhamento permitiu inferir a localização na proteóna $L$ dos vírus da família Bunyaviridae os quatro sítios da proteína PB1 dos vírus da influenza. Os sítios de ligação da 5'vRNA e o de atividade endonuclease para produção de capprimer estão localizados na quarta região conservada da proteina $L$ indicando que exerceriam papel importante na função desta proteína. Finalmente, a proteína $\mathrm{N}$ de ORO foi expressa em E. coli e mostrou-se corretamente montada por apresentar tamanho esperado, de $26 \mathrm{kd}$, à eletroforese em gel de poliacrilamida e por ter sido reconhecida no immunobloting por anticorpos policlonais.

A seqüência nucleotídica completa dos três segmentos de RNA de ORO descrita neste estudo deverá ser de muita utilidade para a síntese de primers específicos a serem utilizados numa RT-PCR para o 
diagnóstico e estudo da epidemiologia molecular desta virose. Também, a produção de proteínas virais recombinantes de ORO, tal como a proteína $\mathrm{N}$, poderam ser utilizadas como antígenos para o desenvolvimento de métodos de diagnósticos sorológicos ou como candidatas a vacinas.

\section{ESTUDO SOBRE A IMUNOGENICIDADE DA PROTEÍNA PLC-a (FOSFOLIPASE-C) DE MYCOBACTERIUM TUBERCULOSIS}

Eduardo Dantas Casillo Gonçalves

Orientador: Prof. Dr. Célio Lopes Silva

Dissertação de Mestrado apresentada em 20/08/2002

O presente trabalho teve como objetivo avaliar a imunogenicidade da proteina fosfolipase-c (PLC-a), espécie-específica de M. tuberculosis, em diferentes esquemas de imunização. Inicialmente, avaliou-se a capacidade das construções contendo o gene que codifica o antígeno PLC-a transfectar células eucarióticas. Nossos resultados mostraram que macrófagos murinos foram capazes de expressar a proteína 72 horas após a transfecção. Uma vez confirmada a expressão da PLC-a, animais Balb/c foram imunizados com: 1) solução de DNA por via intramuscular ou intradérmica; 2) com $M$. bovis (BCG) carreando o vetor de expressão em micobactérias (pmv262) por via intranasal ou subcutânea, ou 3) com $S$. typhumurium carreando o vetor de expressão em células eucarióticas (pcDNA3) por via intranasal ou oral, ambos vetores carreando ou não o gene da PLCa. Nossos resultados mostraram que as imunizações com DNA em solução por via intramuscular e com $S$. typhimurium carreando o gene da PLC-a por via intranasal estimularam uma produção significativa de IgG2a, IL-12 e IFN- $\gamma$. antígeno específica. A resposta induzida foi mais direcionada a um padrão Th1, que caracteriza a ativação de uma resposta celular importante para a proteção contra a TB. No entanto, animais imunizados com DNA em solução ou com Salmonella carreando o gene PLC-a e não desafiados com M. tuberculosis não foram capazes de controlar a infecção, como mostraram os cortes histológicos pulmonares com presença de grande quantidade de bacilos intracelulares. A análise do infiltrado celular pulmonar mostrou presença de linfócitos perivasculares e intensa distribuição de macrófagos no tecido, apresentando também destruição parenquimatosa com edema alveolar. Nesse contexto as imunizações com PLCa apesar de estimularem o desenvolvimento de uma resposta celular, parecem não proteger contra a infecção por M. tuberculosis, mas induzem a formação de uma granuloma mais organizado, que parece conter a carga bacilífera em seu interior. Desse modo, a grande quantidade dos bacilos contidos no interior dos macrófagos pode favorecer a ação de drogas contra a tuberculose, uma vez que conseguem conter alta carga bacilífera dentro de granulomas.

\section{ESTUDO SOBRE A INFECÇÃO POR FLAVIVIRUS BRASILEIROS EM MACRÓFAGOS DE CAMUNDONGOS}

\section{Veridiana Ester Dias de Barros}

Orientador: Prof.Dr. Luiz Tadeu Moraes Figueiredo

Dissertação de Mestrado apresentada em 05/09/2002

As arboviroses representam grave problema de saúde pública no Brasil. Dentre as arboviroses, aquelas transmitidas por mosquitos e causadas por Flavivirus são as mais importantes causadoras de surtos ou epidemias. Flaviviroses, como o dengue e a febre amarela, são responsáveis por doenças humanas de grande morbidade e representativa mortalidade. A fisiopatologia de algumas flaviviroses, como a do dengue na sua forma hemorrágica, relaciona-se à infecção maciça de células macrofágicas.

Esse estudo objetivou investigar a infecção de macrófagos peritoneais de camundongos infectados por diferentes Flavivirus brasileiros. A infecção celular foi inicialmente confirmada por teste de imunofluorescência indireta no qual observou-se fluorescência celular quando comparada à de macrófagos não infectados. O estudo inclui microscopia da varredura na qual macrófagos infectados com o vírus Rocio (ROC), febre amarela (YF), Bussuquara (BUS) e da encefalite de Saint Louis (SLE) apresentaram alterações da forma, tamanho e superficie, com acentuação 
no tamanho dos prolongamentos citoplasmáticos (pseudópodos). À microscopia de transmissão observou-se, independente do Flavivirus infectante, alterações citopatológicas sugerindo grave comprometimento celular. Ocorreu hipertrofia do retículo endoplasmático (rRE) por todo o citoplasma, com aparecimento de grandes vesículas intracitoplasmáticas contendo, no interior, material amorfo e finalmente granulado, com partículas esféricas de tamanho variável, muitas com aproximadamente 50 a $60 \mathrm{~nm}$ de diâmetro, provavelmente, correspondendo a partículas virais em formação. Os macrófagos infectados apresentaram rRE hipertrofiado e com centros eletrondensos, características que podem ser associadas a grande atividade de síntese protéica. Visualizou-se muitos ribossomos livres no citoplasma e, também, foi possível observar o complexo de Golgi com alargamento de suas vesículas. As mitocôndrias apresentaram-se preservadas e sem alterações aparentes. Os núcleos mostraram-se preservados em sua forma e posição, mas freqüentemente exibiam rarefação cromatínica. À imunomicroscopia eletrônica observou-se maior quantidade de partículas de ouro coloidal nos macrófagos infectados quando comparados aos não infectados. Antígenos de Flavivirus foram observados nos macrófagos infectados, em diversos pontos dos citoplasmas, mais freqüentemente em vesículas.

Também, estudou-se a produção de citocinas e óxido nítrico (NO) nos macrófagos infectados com
Flavivirus . Células infectadas com ROC, SLE e BUS não exibiram produção alterada de IL- $1 \beta$, TNF- $\alpha$ e TGF- $\beta 1$. Os macrofagos infectados com YF não mostraram alteração na síntese de IL- $1 \beta$, TNF- $\alpha$ mas inibiram a producão de TGF- $\beta 1$. A estimulação macrofágica com LPS após infecção por ROC, SLE e YF inibiu a produção de IL-1ß e TGF- $\beta 1$. Os virus ROC e BUS inibiram a produção macrofágica de TNF$\alpha$. BUS causou produção aumentada de IL-1ß. Também, verificou-se que os macrófagos infectados com ROC, SLE, YF e BUS apresentaram produção aumentada de NO. Macrófagos estimulados com LPS e infectados com os vírus ROC, SLE e BUS (5000 MOI) mostraram produção aumentada de NO enquanto que os infectados com YF tiveram redução na produção de NO e BUS (500 MOI) não alterou esta produção.

A infecção por Flavivirus brasileiros causa profundas alterações e graves danos às estruturas citoplasmáticas macrofágicas devido à replicação viral. Os vírus e seus produtos foram visualizados em vesículas citoplasmáticas do rRE. Também, a infecção pelos Flavivirus inibe a síntese das citocinas IL$1 \beta$, TNF- $\alpha$ e TGF- $\beta 1$. Estes achados sao de dificl interpretação por que, se algumas alterações de citocinas favoreceriam à replicação viral, outras seriam úteis ao controle da infecção. Entretanto, quanto ao NO, foi nítida a produção aumentada nas células infectadas sugerindo que esta molécula gasosa deva atuar no controle da infecção celular por Flavivirus.

\section{EXPOSIÇÃO DOMICILIAR A ALÉRGENOS EM RIBEIRÃO PRETO: EFEITO DE MEDIDA PARA CONTROLE DA EXPOSIÇÃO A ÁCAROS}

\section{Kátia Regina Coimbra Tobias}

Orientadora:Profa.Dra.Luisa Karla de Paula Arruda Dissertação de Mestrado apresentada em 13/09/2002

Exposição a alérgenos do interior do domícilio incluindo ácaros, baratas, gato, cachorro e fungos, está associada a sensibilização e desenvolvimento de asma e outras doenças alérgicas. No presente estudo, foi avaliada a exposição a alérgenos de ácaros D. pteronyssinus (Grupo 1 e Grupo 2), barata B. germanica (Bla 1 e Bla g 2), gato (Fel d 1), e cachorro (Can $\mathrm{f} 1$ ), em um grupo de 24 pacientes com asma e/ou rinite, alérgicos a ácaros, residentes em Ribeirão Preto. Em um subgrupo de 19 pacientes, foi investigado o efeito da colocação de capas de colchão e travesseiro nos níveis de alérgenos de ácaros.

IgE total elevada ( $\geq 100 \mathrm{kU} / \mathrm{L})$ foi observada em 20/24 (83\%) dos pacientes. Anticorpos IgE específicos no soro, determinados através do sistema CAP (Pharmacia), foram detectáveis para D. pteronyssinus, D. farinae e Blomia tropicalis em $96 \%, 91 \%$ e $83 \%$ dos pacientes, respectivamente; para B germanica em $50 \%$ e para gato e cachorro em $13 \%$ e $26 \%$ dos pacientes, respectivamente.

A quantificação de alérgenos na poeira domiciliar foi feita por ELISA. .Níveis de alérgenos de ácaros do Grupo 1 foram mais elevados nas amostras de cama, quando comparados às da sala de TV, chão do quarto e cozinha (MG 13,4 $\mu \mathrm{g} / \mathrm{g}, 4,5 \mu \mathrm{g} / \mathrm{g}, 0,7 \mu \mathrm{g} / \mathrm{g}$ e $0,12 \mu \mathrm{g} / \mathrm{g}$, respectivamente). Alergenos de barata foram mais elevados nas amostras de cozinha. Alérgenos de gato e cachorro foram encontrados em todos ambientes da casa. Nos dimicílios com cachorro, os níveis de Can $\mathrm{f}$ 1 foram significantemente mais elevados (MG 3,17 $\mu \mathrm{g}$ / 
$\mathrm{g}$ e $0,42 \mu \mathrm{g} / \mathrm{g}$, respectivamente).

A colocação de capas de colchão e travesseiros impermeáveis a ácaros e seus alérgenos foi eficaz em reduzir os níveis de alérgenos do Grupo 1 nas amostras de poeira de cama, até seis meses após a colocação das capas.

\section{COMPARAÇÃO ENTRE PROMOTORES REGULADOS POR PhOP/Q POR MEIO DA EXPRES- SÃO DE GFPmut3(*): CONSTRUÇÃO DE UM SISTEMA PLASMIDIAL PARA EXPRESSÃO ESTÁVEL DE ANTÍGENOS HETERÓLOGOS EM LINHAGENS ATENUADAS DE SALMONELLA ENTERICA TYPHIMURIUM}

\section{Lucinda Giampietro Brandão}

Orientador: Prof. Dr. Marcelo Brocchi

Dissertação de Mestrado apresentada em 11/10/2002

Linhagens recombinantes atenuadas Salmonella enterica Typhimurium atenuadas têm o potencial de serem usadas para apresentação de antígenos heterólogos ao sistema imune. Tais mutantes atenuados para virulência são ainda capazes de causar infecção transitória. Estas linhagens mutantes são capazes de desencadear uma potente resposta imunológica tanto contra o antígeno heterólogo carreado quanto contra os antígenos da própria bacteria. As linhagens recombinantes que não expressam os antígenos de uma forma estável são pouco imunogênicas. Sendo assim, fatores como estabilidade e nível de expressão podem modular a resposta imune aos antígenos quando expressos por estes organismos, podendo desta forma modificar a sua imunogenicidade. Alternativamente, sistemas letais balanceados como os sistema asd foram propostos. Nesse caso, gene essencial ao crescimento da bactéria é deletado de seu genoma e inserido em plasmídios, que servirão como carreadores do gene heterólogo. A estabilidade da expressão é assim garantida, mas a utilizaçãode promotores constitutivos nesses sistemas pode ainda estar associada à indução de fraca resposta imune. Em especial, o desenvolvimento de sistema regulados que expressam antígenos basicamente quando submetidos a condições especiais encontradas no hospedeiro (indução de promotores in vivo), melhora a estabilidade e imunogenicidade da linhagem recombinante. Apesar disso, poucos promotores têm sido explorados para esta finalidade e há necessidade da caracterização de novos candidatos. Dessa forma, a habilidade dos promotores dos genes pagC, pagD, mgtC e phoN em direcionarem a expressão do gene (GFPmut3(*) repórter em linhagens vacinais de S. enterica Typhimurium $\chi 3987 \Delta$ cya $\Delta$ crp $\Delta$ asd e H683 $\Delta$ aroA $\Delta$ asd, foi investigada neste estudo. Todos os quatro promotores sao regulados pelo sistema $\mathrm{PhoP} / \mathrm{Q}$ e são induzidos quando S. enterica está no ambiente intracelular, prin- cipalmente macrófagos. A proteína quinase de membrana, PhoQ, é ativada em baixas concentrações de $\mathrm{Mg}^{2+}$ concentrações micromolares) e fosforila PhoP, que ativa a expressão de pagC, pagD, mgtC e phoN. Os promotores desses quatro genes foram amplificados por PCR e fusionados com o gene GFPmut3(*) (green fluorescent protein - gene repórter) o qual foi obtido por mutagênese sítio dirigida. Plasmídios de alto número de cópias (pYA3137) e de baixo número de cópias (pYA3074) pertencentes ao sistema letal balanceado asd de estabilização foram modificados a fim de serem utilizados nas clonagens das fusões gênicas entre promotor e gene repórter. Estes plasmídios, depois de construídos, direcionaram a expressão de GFPmut3(*) a partir dos promotores. Para isto, os plasmídios foram introduzidos nas linhagens atenuadas de S. enterica Typhimurium $\chi 3987$ e H683. A expressão de gfpmut3(*) foi avaliada sob diferentes condições de crescimento, como em diferentes concentrações de $\mathrm{Mg}^{2+}$ e no ambiente intracelular de macrófagos peritoneais de camundongos BALB/c, por Fluorescent Activated Cell Sort (FACSort) (Becton Dickson), e comparada com a expressão obtida quando um promotor constitutivo ( $\operatorname{trc}$ ) foi usado. Os resultados indicam que a expressão da proteína (GFPmut3(*) a partir do promotor de pYA3137 pagC é a maior entre todos os promotores indutíveis avaliados, mas não é maior do que a resultante na construção com promotor constitutivo trc, freqüentemente usado no desenvolvimento de linhagens recombinantes. Ao cntrário das construções utilizando promotor constitutivo trc, as construções contendo os promotores sob controle do sistema PhoP/Q expressam maior quantidade de GFPmut3(*) na ausência de $\mathrm{Mg}^{2+}$. Os resultados obtidos com as duas linhagens de $\mathrm{S}$. enterica utilizadas sugerem que o genótipo bacteriano influencia na expressão de GFPmut3(*) em diferentes construções. Dessa forma, acredita-se que união do sistema asd com os promotores regulados pode melhorar a imunogenicidade de linhagens vacinais de S. enterica. 


\section{AVALIAÇÃO DA IMUNOGENICIDADE DE DIFERENTES FRAGMENTOS DA VACINA PCDNA-3 hsp65}

Cláudia Andréa Alves de Araújo

Orientador: Prof. Dr. Célio Lopes da Silva

Dissertação de Mestrado apresentada em 19/12/2002

Tem sido recentemente demonstrado que a vacina pCDNA3-hsp65 apresenta atividade profilática e terapêutica experimental. Essa vacina é constituída do gene hsp65 Mycobacterium leprae e fragmento downstream de $1324 \mathrm{pb}$. Entretanto, uma investigação mais refinada da resposta imune desencadeada por diferentes fragmentos do inserto dessa vacina ainda não foi realizada. Também, não foi estudada, a influência do fragmento downstream ao gene hsp65 na indução da resposta imune pela vacina. Para tal propósito, foram construídos subclones da vacina pCDNA3-hsp65, com a colaboração da Dra. Sylvia Cardoso Leão (UNIFESP), para utilização nos esquemas de imunização e nos ensaios para avaliar a resposta imune humoral e celular. As novas construções de DNA foram denominadas pCDNA3-hsp65G ( $\mathrm{G}=$ gene hsp65, para diferenciar da construção vacinal original, que contém gene hsp65 + fragmento downstream), pCDNA3-N ( $\mathrm{N}=\mathrm{N}$-terminal da proteína Hsp65), PCDNA3-N59 (N59 = 59 pb codificante da extremidade N-terminal da Hsp65) e pCDNA3$\mathrm{DS}(\mathrm{DS}=$ downstream).

Camundongos BALB/c foram imunizados por via intradérmica (Gene Gun) ou via intramuscular, com $10 \mu \mathrm{g} / \mathrm{dose}$ ou $100 \mu \mathrm{g} /$ dose, respectivamente. Foram feitas três imunizações com intervalo de 15 dias entre elas; 30 dias após a $3^{\mathrm{a}}$ imunização, os animais foram sacrificados e a resposta imune foi avaliada. A resposta imune humoral foi avaliada pelos títulos de anticorpos IgG, IgG1 e IgG2a anti-Hsp65 através de ELISA. A resposta imune celular foi avaliada utilizando três parametros: proliferação de células totais de baço e linfonodos inguinais por incorporação de timidina triciada, produção das citocinas IL-4, IL-10, IFN-gama e IL-12 Hsp65-específicas por ELISA e determinação do influxo de linfócitos $\mathrm{B}$, linfócitos $\mathrm{T}$ CD4+ e CD8 +, macrófagos e células dendríticas para o baço dos animais imunizados com as construções de DNA.

Por via intradérmica (Gene Gun), as imunizações com as construções a construção vacinal original pCDNA3-hsp65 e pCDNA3-hsp65G, construção contendo somente o gene hsp65 de Mycobacterium leprae, induziram elevados níveis de anticorpos $\mathrm{IgG}$,
IgG1 e IgG2a anti-Hsp65. Essas construções também induziram resposta imune celular específica. Células totais do baço e linfonodos inguinais dos animais imunizados com pCDNA3-hsp65 e pCDNA3-hsp65G proliferaram significativamente na presença de Hsp65 recombinante. A produção das citocinas IL-10, IFNgama e IL-12 antígeno específica foi elevada, caracterizando um perfil misto Th1/Th2, porém com tendência a resposta Th2. Esse dado corroborou com os elevados títulos de anticorpos IgG1 e IgG2a. Também verificou-se um aumento no influxo de macrófagos, células dendríticas, linfócitos B, linfócitos T CD4+e T CD8+ no baço dos animais imunizados em relação aos grupos controles (pCDNA3 e não imunizado). Entretanto, a resposta imune humoral e celular desencadeada pela construção vacinal original pCDNA3-hsp65 foi maior que aquela induzida por pCDNA3-hsp65G. As construções pCDNA3-N, pCDNA3-DS e pCDNA3-N59 não induziram resposta imune específica.

Por via intramuscular, as construções pCDNA3hsp65, pCDNA3-hsp65G e pCDNA3-N induziram elevados títulos de IgG, IgG1 e IgG2a anti-Hsp65, proliferação celular e produção significativa das citocinas avaliadas e aumento do influxo de macrófagos, células dendríticas, linfócitos B, linfócitos T CD4+e CD8+ em comparação com os controles (pCDNA3 e não imunizado). Um perfil Th1 de resposta é induzido por pCDNA3-hsp65, pCDNA3-hsp65G e pCDNA3-N, quando injetadas por via intramuscular, uma vez que elevados níveis de IFN-gama e IL-12, além de elevados títulos de IgG2a, foram detectados. Entretanto, não foram verificadas diferenças na ativação da resposta imune humoral e celular quando as construções pCDNA3-hsp65 e pCDNA3-hsp65G foram comparadas. A construção pCDNA3-N desencadeou resposta imune em menor magnitude que as construções pCDNA3-hsp65 e pCDNA3-hsp65G. As demais construções (pCDNA3-N59 e pCDNA3-DS) não foram imunogênicas.

Esses resultados indicaram que a ausência do fragmento downstream ao gene hsp65 interfere significativamente na ativação da resposta imune humoral e celular pela vacina, quando os animais foram imunizados por via intradérmica (Gene Gun) com pCDNA3hsp65G, construção que não contém o fragmento downstream. Isso sugeriu que existe a provável participação de motifs $\mathrm{CpG}$, presente no fragmento 
downstream, na indução da resposta imune, que foi significativamente diminuída quando esse fragmento foi retirado da construção de DNA pCDNA3-hsp65G. Por outro lado, por via intramuscular, o fragmento downstream parece não interferir no desencadeamen- to da resposta imune humoral e celular pela vacina. Essas diferenças na indução da resposta imune pelo fragmento downstream parecem estar diretamente relacionadas com a quantidade de DNA que é injetada nos animais e com a via de administração do DNA.

\section{PAPEL DA MOLÉCULA DE ADESÃO ICAM-1 NA INFECÇÃO EXPERIMENTAL POR TRYPANOSOMA CRUZI}

Mara Rúbia Nunes Celes

Orientador: Prof. Dr. João Santana da Silva

Dissertação de Mestrado apresentada em 19/12/2002

A miocardite chagásica aguda, causada por Trypanosoma cruzi é caracterizada pela presença de um intenso infiltrado de células mononucleares, rico em leucócitos e macrófagos, extensivo parasitismo das fibras cardíacas e nesta fase da doença não ocorre fibrose, ou esta é discreta. O recrutamento de leucócitos da corrente sanguínea para o miocárdio é uma etapa fundamental para a indução e manutenção da reação inflamatória. As quimiocinas, citocinas e moléculas de adesão como o ICAM-1 (membro da superfamília das imunoglobulinas) tem um papel crucial no recrutamento de leucócitos da corrente sanguínea para o miocárdio, estando entre os principais reguladores deste processo. Durante a fase aguda da infecção, as células endoteliais e os miócitos cardíacos localizados no sítio inflamatório ou próximo a este, apresentam uma aumentada expressão de ICAM-1. A interação entre ICAM-1 presente no endotélio, e as integrinas na superfície dos leucócitos resulta em firme adesão e posterior transmigração das células através do endotélio. Tais achados motivaram o desenvolvimento deste projeto visando avaliar o envolvimento de ICAM-1 na resistência e/ou suscetibilidade à infecção experimental por T. cruzi. Para tal, camundongos selvagens (C57B1/ 6) e geneticamente deficientes de ICAM-1 (ICAM$1^{-/-}$) foram infectados com T.cruzi, cepa Colombiana onde foram avaliadas a parasitemia, mortalidade e miocardite. Nossos resultados mostraram que camundongos deficientes de ICAM-1 foram mais susceptíveis à infecção, desenvolvendo altas parasitemias e maior taxa de mortalidade, quando comparados aos animais selvagens. A quantidade de ninhos de amastigotas no tecido cardíaco e muscular esquelético, e no baço dos animais ICAM-1-1- foi significantemente maior que nos controles (selvagens), embora, o infiltrado inflamatório nos camundongos deficientes de ICAM-1 tenha sido significativamente menor. Foi encontrada também uma redução considerável de ambos linfócitos $\mathrm{T}, \mathrm{CD}^{+}$e $\mathrm{CD}^{+}$nos camundongos ICAM- ${ }^{-1}$. Estes resultados sugerem que ICAM-1 está efetivamente envolvido nos mecanismos de migração celular para o coração e que pode contribuir para o estabelecimento e perpetuação da miocardite induzida por T. cruzi. De forma interessante, nossos resultados também indicam que ICAM-1 contribui para resistência contra a infecção por T. cruzi.

\section{NEUROLOGIA}

\section{ESTUDO PROSPECTIVO DA EVOLUÇÃO ELETRO-CLÍNICA DE CRIANÇAS QUE APRESEN- TARAM PADRÃO DE SURTO-SUPRESSÃO EM POLIGRAFIAS NO PERÍODO NEONATAL}

Heidi Haveisen Sander

Orientadora:Profa. Dra.Regina M. França Fernandes

Dissertação de Mestrado apresentada em 02/08/2002

O surto-supressão é um padrão eletrencefalo- gráfico anormal que pode ser registrado desde o período neonatal, geralmente associado a encefalopatias graves. Nós avaliamos, através de estudo prospectivo, o significado prognóstico do padrão de surto-supressão neonatal em relação ao desenvolvimento neu- 
ropsicomotor e à evolução eletrencefalográfica, com especial ênfase no desenvolvimento de HIPSARRITMIA, durante a fase de lactente.

No período de janeiro de 1997 a julho de 1999 foram avaliadas prospectivamente dezesseis crianças que apresentaram, surto-supressão neonatal em poligrafias realizadas nos berçários do Hospital das Clínicas da Faculdade de Medicina de Ribeirão PretoUSP (HCFMRP). Um grupo controle foi formado por quinze crianças selecionadas ao acaso, no mesmo período, com idades pós-concepcionais semelhantes às das crianças com surto-supressão neonatal e que tinham suspeita de disfunção neurológica sendo, por este motivo, submetidas a poligrafias neonatais, que também mostraram anormalidades outras que não o padrão de surto-supressão. Estas 31 crianças foram acompanhadas nos ambulatórios de Neurologia Infantil e Epilepsia do HCFMRP por período mínimo de um ano, aonde se submeteram a avaliação neurológica e eletrencefalogramas (EEG) sequienciais, bem como a avaliação neurorradiológica e exames sorológicos, bioquímicos e genéticos. Um total de 69 poligrafias e 60
EEG seqüenciais foram realizados, com média semelhante de exames por criança. As características clínicas de Idade Gestacional, Idade Pós-Concepcional na época da realização das poligrafias, peso e etiologias também foram semelhantes entre ambos os grupos. O prognóstico desfavorável foi observado em vinte e quatro crianças, quinze $(62,5 \%)$ do grupo com surtosupressão neonatal e nove $(37,5 \%)$ d grupo controle, sendo pior o prognóstico nas crianças com surto-supressão ( $\mathrm{p}=0.04$, teste de Fisher).

Oito (8) crianças desenvolveram HIPSSARRITMIA na fase de lactente, das quais sete (7) haviam apresentado surto-supressão neonatal e apenas uma era do grupo controle. Esta diferença foi estatisticamente significante ( $\mathrm{p}=0.04$, teste de Fisher). Em cinco (5) destas crianças o padrão de surto-supressão era invariante e duas (2) tinham o padrão variante.

O nível sérico de fenobarbital por ocasião da realização das poligrafias foi semelhante nos grupos com surto-supressão e controle, não parecendo ser fator determinante no desenvolvimento do surto-supressão, nestas crianças ( $\mathrm{p}=0.23$, teste de Mann-Whitney).

\section{ESTUDO DO EFEITO DO STATUS EPILEPTICUS EM RATOS JOVENS E ADULTOS NA IN- DUÇÃO DE NEUROGÊNESE DAS CÉLULAS GRANULARES E REORGANIZAÇÃO SINÁPTICA DAS FIBRAS MUSGOSAS}

\section{Flávia Araújo Guedes}

Orientador: Prof. Dr. João Pereira Leite

Dissertação de Mestrado apresentada em 09/08/2002

A administração de agonistas colinérgicos muscarínicos (polocarpina ou lítio seguido de pilocarpina) em roedores induz o aparecimento de crises límbicas seguidas por crises secundariamente generalizadas (status epilepticus, SE) e, após um período latente os animais apresentam crises espontâneas recorrentes. As alterações comportamentais, eletrencefalográficas e histopatológicas são semelhantes às alterações observadas em pacientes com epilepsia do lobo temporal. Nesses modelos foi observada a existência de brotamento das fibras musgosas na zona supragranular do giro denteado que se assemelham com aquele descritos em tecidocerebral humano com esclerose hipocampal. Estudos recentes demonstraram um aumento na neurogênese das células granulares do giro denteado após a indução de SE pela administração de pilocarpina ou litio-pilocarpina e que esta neurogênese poderia estar associada ao brotamento das fibras musgosas. Entretanto ainda não se sabe qual o papel das células granulares recém geradas na formação do brotamento das fibras musgosas.

O objetivo deste trabalho foi estudar, no modelo experimental do litio-pilocarpina, os fenômenos de neurogênese, brotamento das fibras musgosas e perda neuronal em animais de 15, 21, 40 e 180 dias pós-natais (p15, p21, p40 e p180).

Para avaliar a taxa de neurogênese, animais, nas idades mencionadas acima, foram submetidos a quatro horas de SE por litio-pilocarpina: três dias após foi administrada a bromodeoxiuridina (BrdU) sendo que posteriormente os animais tiveram seus cérebros processados contra imunohistoquímica para BrdU. Para avaliar a intensidade de brotamento das fibras musgosas e perda neuronal animais nas mesmas idades foram submetidos ao SE por lítio-pilocarpina e mortos 60 dias após. Os cérebros foram processados para as coloração de neo-Timm, Violeta de Cresil e Hematoxilina-Eosina (H.E.).

Nossos resultados mostraram que a neurogê- 
nese observada nos animais do grupo p15 diminuiu quando comparado com a dos animais do grupo controle enquanto que os animais do grupo p21 apresentaram uma taxa de neurogênese bastante superior quando comparada com os animais controles. Nos animais com idade pós-natais mais tardias a taxa de neurogênese não aumentou após SE em relação aos animais controles. Os resultados da coloração de neoTimm indicaram que houve um aumento progressivo do brotamento das fibras musgosas com a idade. $\mathrm{Na}$ análise da perda neuronal observamos que os animais mais jovens (p15 e p21) apresentaram uma discreta perda celular, sendo a perda mais evidente nos subcampos CA1 e CA3. Os animais de idades pós natais mais tardias apresentaram uma perda celular mais intensa em todos os subcampos, sendo que a camada de células granulares e o subcampo CA2 estavam relativamente preservados. Nossos resultados indicaram que a neurogênese e o brotamento das fibras musgosas são dois fenômenos independentes, e que o brotamento das fibras musgosas parece estar mais relacionado com a intensidade de perda celular.

\section{O ENVOLVIMENTO DA VIA BRADICININA-ÓXIDO NITTRICO NA IMUNORREATIVIDADE Á PRO- TEÍNA FOS - INDUZIDA PELO ESTÍMULO ELÉTRICO DO SEIO SAGITAL SUPERIOR - NA PORÇÃO CAUDAL DO NÚCLEO ESPINAL DO NERVO TRIGÊMIO: IMPLICAÇÕES NA FISIO- PATOLOGIA DAS CEFALÉIAS PRIMÁRIAS DE ORIGEM VASCULAR.}

\section{Marcelo Cedrinho Ciciarelli \\ Orientador: Prof. Dr. Alexandre Pinto Corrado \\ Tese de Doutorado apresentada em 25/10/2002}

Evidências envolvendo animais e humanos indicam a participação na fisiopatologia das cefaléias primárias, do sistema trigeminovascular (STV) cuja ativação, desencadeia uma inflamação neurogênica (IN), mediada pela serotonina, (5-HT), prostaglandinas $\left(\mathrm{PGE}_{2}\right.$ e $\mathrm{I}_{2}$ ), bradicinina (BC), taquicininas (Sub. P e CGRP), histamina (H) e óxido nítrico (NO), responsáveis pela vasodilatação e aumento de permeabilidade vascular que caracterizam o perfil inflamatório da IN (Moskowitz e cols, 1984, 1989) e das crises dessas cefaléias (Goadsby et al., 1992; Sarchielli et al., 2000), embora nessas últimas o seu sintoma primordial, a dor, continue tema controvertido face à indefinição do(s) agente(s) endógeno(s) especificamente envolvido(s) nesse processo nociceptivo, impedindo a adoção de uma terapêutica mais racional. Em modelo de dor em cães, nosso grupo (Corrado e Balejjo, 1992: Ciciarelli, 1996) confirmou ser a $\mathrm{BC}$ o mais potente agente algógeno conhecido, desencadeando, pela via carotídea (i.c.), uma resposta nociceptiva (RN) representada por hiperpnéia, hipotensão, bradicardia e vocalização, ao contrário das taquicininas, que induzem somente hipotensão, da 5-HT e PGs, que somente confirmaram a atividade hiperalgésica, potencializando a $\mathrm{RN}$ induzida pela BC, e os doadores de NO, tipo SIN-1, que promovem somente hipotensão, fazendo exceção os derivados tiólicos do NO, tipo S-nitrosocisteina
(SNO) que reproduzem integralmente a RN. Face ao exposto, propusemo-nos avaliar o papel da $\mathrm{BC}$ e da $\mathrm{SNO}$, no processo nociceptivo da IN bem como, em vista da BC liberar quantidades apreciáveis de SNO (Rubanyii, 1993), avaliar o envolvimento da via BCSNO nessa nocicepção. Empregamos modelo elaborado para o gato (Kaube et al., 1993) adaptando-o para o rato, que correlaciona quantitativamente os efeitos induzidos por estímulos elétricos no seio sagital superior (SSS), com a atividade neuronal da porção caudal do núcleo espinal do trigêmeo (PCT), avaliada através da imunorreatividade à proteina Fos (Fos-IR).

(1) Os parâmetros estimulatórios adaptado ao rato $(20 \mathrm{~V} ; 0,3 \mathrm{~Hz} .250 \mu \mathrm{s}$, durante $30 \mathrm{~min})$ induziram respostas significativas $(\mathrm{p}<0,05-\mathrm{n}=5)$ da Fos-IR, comparadas com os controles $(\mathrm{n}=2)$ cirurgicamente preparados mas não estimulados (2) $\mathrm{O}$ tratamento prévio (30 $\mathrm{min}$ ) com L-NAME (10 mg/kg i.p.) causou queda significativa $(\mathrm{p}<0,05-\mathrm{n}=3)$ da Fos-IR, confirmando os resultados de Kaube et al., (1993) no gato, sobre a participação do NO nesse processo nociceptivo. (3) 3 ug e $10 u g$ de BC i.c. induziram Fos-IR dose-dependente e significativas ( $\mathrm{p}<0,05, \mathrm{n}=6$, para 3 ug e $\mathrm{p}<0,01$, $\mathrm{n}=8$ para $10 \mathrm{ug})$ em relação aos controles (10 ul de salina usada como solvente, $n=5$ ). (4) $O$ tratamento prévio com L-NAME $(10 \mathrm{mg} / \mathrm{kg}$ i.p.) causou queda significativa ( $p<0,05 n=4)$ da Fos-IR induzida por 10 ug de $\mathrm{BC}$ indicando a participação da via nitrérgica no processo nociceptivo induzido pela BC. A salina $(0,3$ $\mathrm{ml}$ i.p) usada como solvente do L-NAME não teve influência significativa nos efeitos da $B C(p>0,05$ $n=4)$. (5) A significativa FosIR induzida pela SNO 
$(\mathrm{p}<0,001$ - $n=6)$, que não sofreu alterações significativas pelo tratamento prévio $(30 \mathrm{~min})$ com L-NAME $(10 \mathrm{mg} / \mathrm{kg}$ i.p.), confirma os resultados obtidos no modelo de dor em cães e reforça o aventado papel desses derivados tiólicos, no sistema nitrérgico, prováveis ativadores dos nociceptores, tornando altamente sugestiva a sua mediação na dor induzida pela $\mathrm{BC}$, constituindo a via BC-SNO. (6). Confirmando a participação de receptores $\mathrm{B}_{2}$ em estímulos nociceptivos provocados pela $\mathrm{BC}$, a injeção prévia $(10 \mathrm{~min})$ do bloqueador seletivo desses receptores (HOE 140 - 400 $\mu \mathrm{g} / \mathrm{kg}$ i.p.) causou uma queda significativa da Fos-IR induzida por $10 \mu \mathrm{g}$ de $\mathrm{BC}(\mathrm{p}<0,001 \mathrm{n}=4)$. (7) A aplicacão prévia (30 min) do captopril (1 mg/kg i.p.), inibidor da cininase II inativadora da $\mathrm{BC}$, potencializou de forma significativa $(p<0,001-n=5)$ os efeitos induzidos por 3 $\mu \mathrm{g}$ de BC. Assinale-se que sendo a cininase II a propria enzima conversora das angiotensiva (ECA), depreende-se o largo emprego do captopril em terapêutica antihipertensiva e, portanto, o seu uso deverá ser reavaliado caso se demonstre o envolvimento da via BC-SNO nos processos dolorosos do segmento cefálico pois, nesta eventualidade, além da freqüente tosse seca e do raro angioneurótico, conhecidos efeitos adversos da terapêutica com os inibidores da ECA, diretamente relacionados com o aumento da $\mathrm{BC}$ no plasma e nos tecidos, deverão ser também considerados, nos pacientes hipertensos e geneticamente predispostos às cefaléias primárias, eventuais efeitos dolorosos do segmento cefálico. (8) Tal possibilidade tornou-se altamente sugestiva ao demonstrarmos a capacidade de o HOE $140(400 \mu \mathrm{g} / \mathrm{kg}$ i.p. $)$ reduziu de forma significativa ( $p<0,05-n=3$ ) a FosIR induzida pelo estimulo elétrico do SSS, indicando a via BC-SNO na gênese desse estímulo nociceptiovo, com possíveis implicações na fisiopatologia e terapêutica das cefaléias primárias. Havendo sido demonstrado que o emprego do HOE 140 em ensaios clínicos, visando a sua eficácia em afecções do trato respiratório envolvendo a BC como agente causal, não ter apresentado efeitos colaterais importantes (Akbary et al., 1996), torna-se sugestivo o seu ensaio clínico como uma nova alternativa terapêutica para o tratamento das cefaléias de origem vascular.

\section{SOBRE O DIAGNÓSTICO DE CRIANÇAS SEGUIDAS EM UM PROJETO "ESTIMULAÇÃO PRECOCE" ENFOQUE NOS FATORES DE RISCO E PREVENÇÃO}

\section{Luiza Helena Acerbi Caran}

Orientadora:Profa.Dra.Carolina A. R. Funayama

Dissertação de Mestrado apresentada em 28/11/2002

O conhecimento, em nível regional, das causas que levam as crianças a um Programa de Estimulação Precoce, permite o estudo dos fatores de risco e direciona metas locais de prevenção de deficiências. Com o intuito de obter este conhecimento, foram avaliadas, no período de setembro de 1999 a junho de 2001, 73 crianças de 1 a 47 meses de idade, em atendimento no projeto "Estimulação Precoce" na Associação dos Pais e Amigos dos Excepcionais (APAE) de Batatais, cidade do interior do estado de São Paulo. Foi utilizado um protocolo de atendimento médico neurológico inicial, previamente elaborado pela autora, aplicado como rotina de primeira consulta em todos os pacientes encaminhados à instituição, com quesitos como fatores de risco maternos, gestacionais e perinatais e intercorrências clínicas subsequientes, além de dados de desenvolvimento neuromotor, antecedentes familiares, exame clínico e exames subsidiários. Para a obtenção do maior número possível de dados, foram consultados os prontuários das crianças (nascimento e seguimento) e mães (pré-natal), na Rede Pública de Saúde - Postos de Saúde, Hospital de Batatais e Hospital das Clínicas de Ribeirão Preto. Para a elaboração do diagnóstico etiológico, foram também obtidos dados de avaliação do Serviço de Pediatria da APAE e do Programa de Residência de Genética Médica do Hospital das Clínicas de Ribeirão Preto, em estágio curricular na APAE. Inicialmente, as 73 crianças foram subdivididas em grupos a partir dos achados ao exame clínico: Distúrbios motores (30\%); Dismorfias ou Malformações (26\%); Desnutrição (15\%); Macrocefalia (11\%); Microcefalia (10\%) e Retardo do Desenvolvimento Neuromotor sem outros sinais (8\%). Procedeu-se, a seguir, à identificação, em cada grupo, dos fatores de risco, antecedentes e exames subsidiários. A partir das informações obtidas, foi possível elucidar os fatores causais em $64 \%$ do total de crianças, sendo $37 \%$ de causas ambientais, $23 \%$ genéticas, $3 \%$ provavelmente genéticas e $1 \%$ multifatoriais. Evidenciou-se que: 1- ainda são relevantes em nosso meio fatores ambientais que levam à encefalopatia hipóxico-isquêmica 
e infartos cerebrais no feto ou neonato, com conseqüente paralisia cerebral; e também à desnutrição como causa de atraso no desenvolvimento; 2- a alta taxa de contribuição dos dados colhidos para o diagnóstico e análise dos fatores de risco foi indicativa da aplicabilidade do protocolo de avaliação proposto; entretanto, conclui-se, que o protocolo precisa fazer par- te de uma avaliação continuada. Propõe-se que as informações tenham um fluxograma pré-determinado, permitindo seguimento eficaz desde a pré-concepção, com documentação informatizada e acessível, com vistas a este seguimento por todas as equipes de saúde ou profissionais individualmente por onde passa a criança, a mãe e a família.

\section{OFTALMOLOGIA}

\section{DESCOMPRESSÃO ORBITÁRIA NA ORBITOPATIA DE GRAVES: COMPARAÇÃO ENTRE TRÊS TÉCNICAS CIRÚRGICAS}

\author{
Valmor Rios Leme \\ Orientador: Prof.Dr.Antonio Augusto Velasco e Cruz \\ Tese de Doutorado apresentada em 09/08/2002
}

Foram estudadas 112 órbitas, de 63 pacientes submetidos à descompressão orbitária. Três modalidades descompressivas foram utilizadas: a descompressão D1 combinava a retirada da parede lateral à descompressão D2, que era o acesso transconjuntival ínfero-medial. A descompressão D3 abordava as paredes medial, teto e assoalho por via coronal.
Dos pacientes que apresentavam neuropatia óptica no pré-operatório, $70 \%$ melhoraram a função visual independente da técnica utilizada. $\mathrm{O}$ efeito descompressivo médio obtido com D2 foi de $4,37 \mathrm{~mm}$. Quando combinada à retirada da parede lateral D1, esse efeito foi acrescido de $0,36 \mathrm{~mm}$, valor estatisticamente não significativo. Na descompressão D3, o efeito descompressivo médio foi de $5,76 \mathrm{~mm}$, estatisticamente diferente do das outras duas.

As três técnicas mostraram-se eficazes e seguras, sendo que a técnica D2 demonstrou ser a de melhor relação custo/beneficio.

\section{TRACOMA EM ÍNDIOS YANOMAMI DO MÉDIO RIO NEGRO}

\section{Jayter Silva de Paula}

Orientador:Prof.Dr.Antonio Augusto Velasco e Cruz Tese de Doutorado apresentada em 01/11/2002

Os Yanomami constituem um dos últimos grupos indígenas primitivos do Brasil. Eles passaram a ter, apenas ultimamente, algum contato com outras culturas, sendo que aspectos epidemiológicos de doenças oculares entre os Yanomami são virtualemnte desconhecidos. Um estudo de tracoma foi realizado, pela primeira vez, entre índios Yanomami da floresta tropical do estado do Amazonas, próximo à divisa com a Venezuela. Exames oftalmológicos foram realizados num total de 613 indivíduos (338 homens e 275 mulheres) de oito comunidades Yanomami ao longo do Rio
Marauiá, localizado nas proximidades da região do Alto Rio Negro. As faixas etárias foram divididas em 3 categorias (crianças, adultos e idosos). O tracoma se mostrou endêmico em todas as comunidades visitadas. De modo geral, 30,3\% dos indivíduos apresentavam tracoma. As mulheres foram significativamente mais afetadas $(37,4 \%)$ que os homens $(23,9 \%)$. As formas de tracoma inflamatório alcançaram prevalência de $24,9 \%$ em crianças e a forma cicatricial alcançou $13,9 \%$ entre os adultos e $35,21 \%$ entre os idosos. Triquíase e opacidades corneanas não foram detectadas. A observação de tracoma endêmico entre os Yanomami é um fator relevante para se entender a epidemiologia da doença na floresta tropical brasileira e demonstra a necessidade de um programa de controle de tracoma nessa região. 


\section{ANÁLISE DE UMA TÉCNICA DE MEDIDA OBJETIVA DA TORÇÃO OCULAR}

\author{
Maria Cristina Nanako Kobayashi \\ Orientador: Prof. Dr. Harley Edison Amaral Bicas \\ Tese de Doutorado apresentada em 08/11/2002
}

A torção ocular tem sido alvo de pesquisa por cerca de dois séculos, entretanto, sem um método que consiga quantificá-la facilmente. Os métodos descritos deparam-se com falhas técnicas. O estudo descreve método desenvolvido para quantificar objetivamente o desvio torcional em estrabismos. Desenvolvido sistema para captura de imagem pelo alinhamento dos eixos ântero-posterior ocular e da câmera com auxílio de mentoneira, apoio de testa e fixador de cabeça. Foram analisadas imagens "digitalizadas", cuja boa definição foi possibilitada por uma lente macrobjetiva de $100 \mathrm{~mm}$, em posição primária do olhar e em posição de desvio, com o sistema reproduzindo o mesmo movimento sofrido pelo olho. Avaliados pacientes com desvio horizontal comparados a pacientes normais, cujos olhos efetuaram movimentos de abdução e/ou adução sem inclinação de cabeça. A medida da possível torção foi realizada por meio de dois pontos fixos escolhidos arbitrariamente na superficie ocular, próximos ao limbo corneal de cada paciente; a diferença da posição da linha formada entre esses dois pontos corresponde ao valor da torção. A variação do erro do método é de $2,42 \%$ a $3,97 \%$, logo, pode ser reproduzido e para se conseguir uma torção com precisão de $1^{\circ}$ o número de medidas necessárias para cada paciente é de 1,58 a 5,48; o valor de torção quantificada foi da ordem de $12^{\circ} \mathrm{em}$ estrábicos e em pessoas normais, sendo que se verifica intorção e a extorção tanto no olho direito quanto no esquerdo.

\section{ORTOPEDIA, TRAUMATOLOGIA E REABILITAÇÃO}

\section{ESTUDO RETROSPECTIVO DOS TRAUMATISMOS DE MÃOS E DEDOS ATENDIDOS NO HOSPITAL DAS CLÍNICAS DA FACULDADE DE MEDICINA DE RIBEIRÃO PRETO NO ANO DE 2000}

\section{Marisa de Cássia Registro Fonseca \\ Orientador: Prof. Dr. Nilton Mazzer \\ Tese de Doutorado apresentada em 17/12/2002}

Um estudo retrospectivo foi realizado com pacientes que deram entrada na Unidade de Emergência do Hospital das Clínicas de Ribeirão Preto, Brasil, num período de janeiro a dezembro de 2000 , com lesões traumáticas nas mãos. O objetivo foi descrever a distribuição dos dados dessa população de pacientes e propor a formulação de uma campanha de prevenção de acidentes com as mãos. $\mathrm{O}$ estudo epidemiológico foi realizado mediante investigação feita nos prontuários médicos desses pacientes. Um sistema de processamento de texto, banco de dados e estatística para epidemiologia em microcomputadores EPI INFO 6,04D foi usado para armazenar e analisar as informações. Os resultados revelaram que, em uma amostra aleatória simples de 355 pacientes investigados, a idade mé- dia foi $27,3 \pm 16,7$ anos, variando entre 1 mês até 88 anos. A mão dominante não foi informada na maioria dos prontuários. Estudantes (28\%) e profissionais que lidam com máquinas e ferramentas $(24 \%)$ foram as atividades mais acometidas. As mãos direita e esquerda foram lesadas quase igualmente. A incidência de lesões isoladas foi $73,2 \%$. Acidentes de trânsito e lacerações com vidro e serras foram as causas mais comuns das lesões, acarretando freqüentes diagnósticos de fraturas (33\%) e lesões tendinosas $(20,3 \%)$. As crianças do sexo masculino sofreram freqüentes fraturas $(28,6 \%)$ e as crianças do sexo feminino sofreram freqüentes queimaduras $(28,6 \%)$. Conclui-se que a incidência das lesões traumáticas das mãos é alta, e a redução desse tipo de acidente pode acontecer com um resultado de um processo de educação, envolvendo a população, profissionais da saúde, educadores, representantes de entidades e governo em programas de prevenção. 


\section{SÍNDROME DO IMPACTO DO OMBRO. ANÁLISE CRÍTICA DA DESCOMPRESSÃO SUBACROMIAL ENDOSCÓPICA}

\section{Dagoberto de Oliveira Campos}

Orientador: Prof. Dr. Cláudio Henrique Barbieri

Tese de Doutorado apresentada em 18/12/2002

A descompressão subacromial endoscópica apresenta-se como alternativa ao tratamento cirúrgico aberto convencional da síndrome do impacto. $\mathrm{O}$ objetivo deste trabalho foi realizar um estudo crítico da técnica endoscópica visando analisá-la como forma de tratamento, avaliar prospectivamente os resultados obtidos e, investigar as condições potencialmente capazes de influenciar nos resultados. Realizou-se a descompressão endoscópica do manguito rotador em 42 pacientes (43 ombros), os quais foram avaliados clinicamente nas fases pré e pós-operatórias, assim como submetidos ao tratamento cirúrgico, exclusivamente pelo autor deste estudo. Os critérios iniciais para a exclusão de pacientes consistiram na coexistência de rupturas completas do manguito rotador ou do tendão da porção longa do bíceps, de instabilidade glenoumeral e de capsulite adesiva. Os pacientes foram divididos em 3 grupos, conforme o tipo de atividade desempenhada. O grupo I era constituído por 17 pacientes, cujas atividades profissionais exigiam o uso do braço predominantemente acima do nível do horizonte; o grupo II, por 15 pacientes (16 ombros), cujas funções eram predomi- nantemente abaixo do nível do horizonte; e o grupo III, formado por 10 pacientes que executavam apenas atividades cotidianas, sem vínculo empregatício. O teste da injeção de anestésico de Neer, realizado na fase préoperatória em todos os pacientes, revelou ser importante no prognóstico dos resultados obtidos. A descompressão subacromial endoscópica apesar de eficiente como método de tratamento, demonstrou complexidade na sua implementação. A possibilidade de inventariar o espaço articular confere a ela condições exclusivas em relação aos procedimentos restritos ao espaço subacromial. A avaliação dos resultados foi realizada com base no protocolo de pontuação da Universidade da Califórnia (UCLA), cuja variação total média entre as fases pré e pós-operatórias revelou diferença altamente significante, corroborado sujetivamente por um elevado índice de satisfação individual. O desbridamento das lesões parciais do manguito rotador, em pacientes com atividades que não exigem esforços acima do nível do horizonte, mostrou-se eficaz como forma de tratamento. A avaliação dos resultados revelou que o período de tempo para o retorno pleno às atividades pessoais e profissionais mostrou-se prolongado. Conclui-se que a descompressão endoscópica do manguito rotador, embora tecnicamente complexa, é uma alternativa confiável e aprimorada para o tratamento da síndrome do impacto.

\section{OTORRINOLARINGOLOGIA}

\section{CRICOTIREOIDOSTOMIA:AVALIAÇÃO DE UM INSTRUMENTO CIRÚRGICO}

\section{Guido Antonio Marques Bighetti}

Orientador: Prof. Dr. Rui Celso Martins Mamede

Dissertação de Mestrado apresentada em 25/10/2002

A cricotireoidostomia tem se mostrado um método cirúrgico eficiente nas emergências médicas, quando o suporte ventilatório se impõe como medida extrema para preservar a vida.

A falta de um instrumento adequado ao pro- cedimento pode provocar complicações, imediatas ou tardias, nos pacientes a ela submetidos.

Neste trabalho, foi testado um instrumento cirúrgico para realizar a cricotireoidostomia. Esse instrumento, o cricotireóstomo, consiste em um tubo metálico, cilíndrico e curvo, com uma haste horizontal e um mandril de ponta cortante.

Assim construído, foi usado em seis pacientes em iminente risco de morte. A experiência mostrou que o modelo inicial do cricotireóstomo era limitado e neces- 
sitava de adaptações. Foram feitas então algumas modificações, como o fechamento do orifício acessório de ventilação, o aumento do comprimento e da superfície de corte da extremidade distal do tubo e do mandril e o uso da sonda de Foley como alternativa para impedir, quando necessário, a entrada de sangue no conduto laringotraqueal.

Um instrumento adequado pode diminuir signi- ficativamente as complicações imediatas da cricotireoidostomia (sangramento, falso trajeto, lesão das paredes laríngeas), tão comuns quando se usa bisturi ou faca.

O modelo final do cricotireóstomo mostrou-se capaz de, ao penetrar na laringe, promover a ventilação do paciente até mesmo na ocorrência de sangramento.

\section{PATOLOGIA}

\section{ASSOCIAÇÃO ENTRE INFECÇÃO VIRAL PELO EPSTEIN-BARR E EXPRESSÃO DE P63 e P53 NO CARCINOMA MAMÁRIO}

\author{
Alfredo Ribeiro da Silva \\ Orientador: Prof. Dr. Sérgio Zucoloto \\ Tese de Doutorado apresentada em 23/08/2002
}

Recentemente verificou-se correlação entre infecção viral pelo Epstein-Barr (EBV) e o desenvolvimento do carcinoma mamário, mas o mecanismo pelo qual isso ocorre não está claro. O gene p63 é um análogo do gene supressor tumoral p53 cujo papel nas neoplasias necessita ser melhor investigado. Este trabalho tem por objetivo verificar a possível associação do EBV com o p63 e p53, assim como a relação do p63 com o p53, no carcinoma mamário. Oitenta e cinco carcinomas mamários foram submetidos ao método imuno-histoquímico com os anticorpos anti-EBVEBNA1, anti-p63, anti-actina muscular (1A4), anti-p53, anti-receptor de estrógeno (RE) e anti-receptor de progesterona (RP). Os carcinomas positivos para o p63 também foram submetidos à dupla marcação imunohistoquímica utilizando-se o p63 com o 1A4, citoceratina 7 (CK7) e 34ßE12. Os dados clinicos e histopatológicos foram obtidos dos prontuários médicos (idade, menopausa, estadiamento patológico, tamanho tumoral e acometimento linfonodal). O p63, assim como o 1A4, marcou uma camada única de céulas circundando os ductos e ácinos de tecido mamário normal. No carcinoma intraductal o p63 mostrou positividade contínua em apenas 5 dos 12 casos avaliados. Nos carcinomas, o EBV e p53 foram expressos em $37,64 \%$ e $21,17 \%$ dos casos, respectivamente, enquanto o p63 foi expresso apenas em carcinomas pouco diferenciados $(11,76 \%$ do total). Houve correlação entre a expressão do EBV e do p63 (p 0,0005), mas não entre o EBV e o p53 (p 0,1018). Apenas um dos carcinomas positivos para o p63 co-expressou p53. As células neoplásicas positivas para o $\mathrm{p} 63$ co-expressaram o 1A4 e o 34ßE12, mas não a CK7. Houve correlação do EBV com tipo histológico, sendo mais freqüente no carcinoma ductal pouco diferenciado. $\mathrm{O}$ p63 correlacionou-se com o estadiamento patológico, tamanho tumoral, grau histológico, acometimento linfonodal e negatividade para RE. Concluindo, existe correlação entre a expressão do EBV e do p63, mas não do p53, no carcinoma mamário. O p63 marca especificamente as células mioepiteliais no tecido mamário normal, mas não pode ser usado como um marcador confiável para detectar micro-invasão nos carcinomas intra-ductais. O p63 raramento é expresso em carcinomas invasores, sendo um marcador de indiferenciação tumoral. Nos carcinomas ductais, as células malignas positivas para o p63 possuem imunofenotipo semelhante às células mioepiteliais, sugerindo que os tumores positivos para o p63 se originam de células progenitoras mamárias primárias que sofrem diferenciação divergente para células ductais e mioepiteliais durante a expansão clonal. Os dados do presente estudo não favorecem um papel direto do p63 na tumorigênese mamária. Entretanto, o p53 raramente é co-expresso com o p63, sugerindo que o p63 possa atuar indiretamente como um oncogene por inibir o p53. Essa hipótese também poderia explicar porque o p63 correlacionou-se com vários fatores de mau prognóstico. 


\section{EXTRAÇÃO E QUANTIFICAÇÃO DE DNA DE CÉLULAS OBTIDAS POR IMPRINTS E RASPA- DOS DE FÍGADO}

\author{
Camila Nunes de Morais Ribeiro \\ Orientador: Prof. Dr. Luiz Cesar Peres \\ Dissertação de Mestrado apresentada em 26/07/2002
}

As anomalias congênitas estão presentes em cerca de $30 \%$ das necropsias pediátricas realizadas no HCFMRP-USP e já representam a primeira causa de morte pós-neonatal na cidade de Ribeirão Preto, constituindo-se em um verdadeiro problema de saúde pública. A definição diagnóstica destes casos, fundamental para permitir ações no âmbito médico-hospitalar bem como das políticas do setor, é muitas vezes difícil, motivo pelo qual diferentes tipos de investigação devem ser utilizados. Um destes recursos é a análise do DNA, seja por PCR ou outras técnicas moleculares, que pode ser obtido de diferentes fontes e formas de fixação. No entanto, várias dificuldades surgem quando se utilizam tecidos fixados rotineiramente em formol, incluidos ou não em parafina, que se constituem nas formas mais comuns de tecidos disponíveis para exame nos Departamentos de Patologia. O objetivo do presente trabalho foi desenvolver um protocolo simplificado e de baixo custo para a coleta e fixação de células oriundas de tecido hepático de necropsias pediátricas com o intuito de se determinar se o DNA extraído apresentava-se em quantidade e qualidade adequadas, contornando os problemas da fixação em formol ou inclusão em parafina. Para tanto, foram colhidos imprints (grupos I) e raspados (grupos R) de fígado de 15 casos de necropsias pediátricas fixados em etanol 95\% (grupos 195 e R95), por dez minutos e em metanol:ácido acético (3:1), por 45 segundos (grupos IMA e RMA). O material obtido de uma única lâmina de cada caso dos quatro grupos foi submetido à extração de DNA com Wizard® Genomic DNA Purification Kit, Promega, que foi quantificado. Posteriormente, o DNA de cinco casos de cada grupo foi submetidos à amplificação por PCR multiplex do gene AZF. Os resultados mostraram que houve grande variação da quantidade de DNA extraído em todos os grupos, de $20 \mathrm{ng} / \mu \mathrm{L}$ a $8640 \mathrm{ng} / \mu \mathrm{L}$, com media de $1071,33 \mathrm{ng} / \mu \mathrm{L}$ para o grupo $195,717 \mathrm{ng} / \mu \mathrm{L}$ para IMA, $4127,33 \mathrm{ng} / \mu \mathrm{L}$ para R95 e $1774 \mathrm{ng} / \mu \mathrm{L}$ para RMA. Analise estatística não paramétricas de Kruskal Wallis apontou diferença estatisticamente significante entre eles, sendo que o melhor foi o raspado fixado em etanol 95\%. No entanto, a média de todos os grupos foi superior à quantidade necessária para PCR ou Southern Blot. Da mesma forma, não houve diferenças qualitativas avaliadas pela amplificação por PCR entre os diferentes materiais e fixadores. Conclui-se que, apesar dos raspados fixados em etanol $95 \%$ serem comparativamente melhores do que os outros, os imprints fixados em etanol 95\% também são uma boa fonte de DNA, apresentando maiores facilidades de fixação do que os raspados. Os imprints permitem ainda a avaliação citológica e FISH pela não superposição de células, sendo portanto uma fonte mais versátil do que os raspados. Desta forma, os imprints de fígado fixados em etanol 95\% deverão ser incorporados ao protocolo de investigação de anomalias congênita humanas no HCFMRP-USP.

\section{RADICAIS LIVRES, GLUTATIONA E ALFA TOCOFEROL NO FÍGADO E NA MUSCULATURA ESQUELÉTICA, APÓS ESFORÇO FÍSICO AGUDO EM RATOS SEDENTÁRIOS}

\section{José Alexandre Bachur}

Orientador: Prof. Dr. Sérgio Zucoloto

Dissertação de Mestrado apresentada em 07/10/2002

No estresse oxidativo, resultante do desequilibrio entre os radicais livres (RL) gerados e a capacidade dos sistemas antioxidantes, o nível da Peroxidação Lipidica (PL), avaliada pela concentração de malondealdeído (MDA), geralmente é maior, podendo comprometer a integridade celular. Embora alguns estudos sugiram que os RL, sejam deletérios às estruturas celulares, outros atribuem a estes radicais a propriedade de atuarem inicialmente como elementos chaves na indução de alguns processos celulares adaptativos. No presente estudo, objetivou-se analisar as concentrações médias de MDA, de glutationa reduzida (GSH) e de vitamina $\mathrm{E}$, no fígado e no músculo esquelético de ratos sedentários, submetidos ao esforço físico agudo realizado em água, com duração de 50' e 100', sob as intensidades baixa, média e alta, respectivamente relativas às sobrecargas corpóreas (SCC) de $0 \%, 3 \%$ e $5 \%$ do peso corporal. Para tanto, foram utilizados 38 ratos machos da raça Wistar, divididos nos grupos A (esforço físico por 50'), B (esforço físico por 100') e C (grupo controle). Os grupos A e B foram subdivididos em I, II e III representando 
respectivamente as intensidades baixa, média e alta. Os animais foram sacrificados sob anestesia induzida pelo éter sulfúrico, com a subsequente retirada de fragmentos de figado e de músculo gastrocnêmio para estudos morfológicos e bioquímicos através da dosagem das concentrações de MDA, GSH e vitamina E.

À microscopia óptica, não houve lesões dignas de nota no fígado e no músculo esquelético. Porém, observou-se no fígado que, independentemente da sobrecarga corpórea que, a PL é maior aos 50' em relação ao grupo controle e ao período de 100'. No músculo gastrocnêmio, a PL também foi maior aos 50 ' em todas as intensidades. Aos 100', com 3\% de SCC a PL manteve-se semelhante ao grupo controle enquanto que, nas situações onde o esforço físico foi realizado sem SCC ou com 5\% de SCC, a PL foi maior. Houve consumo maior de GSH aos 50' tanto no fígado quanto no músculo esquelético. Aos 100', nas três diferentes intensidades, as concentrações médias de GSH no fígado, mantiveram-se semelhantes a do grupo controle. No músculo gastrocnêmio, o consumo de GSH manteve-se maior ao longo dos 100', somente no esforço de baixa intensidade. $\mathrm{O}$ consumo de vitamina $E$ no fígado foi maior nas situações de média e alta intensidades aos 50' e aos 100'. No músculo gastrocnêmio, foi maior somente nas situações de média e alta intensidades aos 100'.

Estes dados permitem, concluir que, os primeiros 50' de esforço físico agudo, independentemente da intensidade de sua realizaçao, se caracteriza como um período crítico devido ao intenso stresse oxidativo, tanto no fígado quanto no músculo esquelético. Nestes tecidos, os sistemas antioxidantes atuam de maneira sinérgica, sendo o GSH primário em relação à vitamina E. A correlação deste sinergismo antioxidante a intensidade e duração do esforço fisico realizado, sugere que, os RL gerados possam agir como sinalizadores dos sistemas biológicos.

\section{MITOSE E APOPTOSE EM ESTADOS PROLIFERATIVOS ENDOMETRIAIS COM A VALIAÇÃO IMUNOHISTOQUÍMICA PARA B CL2, KI 67 E RECEPTORES DE ESTRÓGENO E PROGESTERONA}

\section{Margarida Maria Fernandes da Silva Moraes Orientador: Prof. Dr. Edson Garcia Soares \\ Dissertação de Mestrado apresentada em 28/10/2002}

Com o objetivo de apreciar o valor da contagem de mitoses e corpos apoptóticos em condições endometriais de proliferação epitelial benígnas e malígnas, foram selecionadas 87 pacientes com estados de proliferação endometrial que variavam desde o normal até adenocarcinoma endometrioide bem diferenciado (grau I). As idades variaram de 23 a 89 anos (média de 52,40 anos).

Os casos foram assim distribuidos: 14 casos de endométrios normais, 12 de disfuncionais, 10 hiperplasia simples, 13 de adenocarcinoma bem-diferenciado endometróide e 38 casos de polipos endometriais sem atipia. A distribuição normal, para todas as circunstâncias, foi avaliada pelo teste de Kolmogorov-Smirnov. Os testes paramétricos foram usados em condições de distribuição normal e os não paramétricos (KruskaWallis, Wilcoxon e Mann-Whitney) para as condições com distribuição que diferia da normal.

A contagem de mitoses e corpos apoptóticos foi feita em 1000 células, em 10 campos de grande aumento (400x). Da mesma maiera foram estudadas as situações de imunomarcação em relação à expres- são de bcl-2, dos receptores hormonais para estrógeno (RE) e progesterona (RP) e da proteína ki-67. Foi possível apreciar uma clara diferença na frequencia de corpos apoptóticos $(\mathrm{p}<0.0001)$ para adenocarcinoma em comparação com as outras alterações benignas (teste de Kruskall-Wallis). Uma correlação inversa entre bcl-2 e apoptose pode ser demonstrada em relação às doenças proliferativas benignas e malignas. $\mathrm{O}$ grau mais alto de expressão de ki-67 foi detectado na hiperplasia simples, assim como a expressão do bcl-2 e receptores para estrógeno e progesterona. A quantidade de receptores esteróides nos adenocarcinomas foi a mais baixa de todas, e também foram os mais baixos, nestas lesões, os valores de expressão de ki67 e bcl-2. A contagem de mitose não foi significante para separação entre lesões benignas e malignas, neste material. No entanto, houve uma indicação de que a contagem de corpos apoptóticos pode ser utilizada como elemento de diferenciação entre estes grupos de lesões. Os dados não são conclusivos, mas representam hipóteses que podem ser averiguadas em estudos subsequentes, com maior amostragem. Portanto, pode ser interessante orientar os patologistas cirúrgicos a começar a olhar para a apoptose como uma nova arma no diagnóstico diferencial do endométrio, como tem sido mostrado para outros órgãos e tecidos. 


\title{
DETERMINAÇÃO DE UM PROTOCOLO DE INVESTIGAÇÃO DE ANOMALIAS CONGÊNITAS ATRAVÉS DA HIBRIDAÇÃO IN SITU FLUORESCENTE (FISH) EM IMPRINTS CELULARES DE FÍGADO
}

\section{Patricia Leite de Godoi Adachi}

Orientador: Prof. Dr. Luiz Cesar Peres

Dissertação de Mestrado apresentada em 05/12/2002

A frequiência de anomalias congênitas como causa de mortalidade infantil tende a crescer proporcionalmente, na medida em que as causas de morte evitáveis, tais como prematuridade e suas conseqüências, infecções e desnutrição, podem ser melhor controladas em função da melhoria geral da saúde da população e do próprio sistema de saúde. No Hospital das Clínicas da Faculdade de Medicina de Ribeirão Preto, as anomalias congênitas representam cerca de um quarto dos casos das necropsias pediátricas, sendo que muitas não têm sua etiologia definida com os recursos disponíveis, pois a cultura celular para a análise de cariótipo, apesar de ter grande valia para o estudo das anomalias congênitas, nem sempre tem sucesso, ora porque os tecidos não são mais cultiváveis, ora por contaminação bacteriana ou fúngica. Por outro lado, muitas vezes a citogenética convencional não é capaz de detectar certas alterações estruturais, como as microdeleções, que devem então ser investigadas com técnicas moleculares. Uma das possibilidades neste sentido é a utilização da Hibridação in situ fluorescente (Fluorescent in situ hybridization - FISH), que pode ser realizada tanto em células em metáfase como em interfase. Apesar de tecnicamente possível, a utilização de tecidos fixados em formol e emblocados em parafina tem muitas limitações, o que motivou a busca de um novo método de análise celular adequado e de baixo custo, representado pelo uso de touch preparatives ou imprints. O objetivo deste trabalho foi determinar um protocolo simplificado e de baixo custo para a investigação de anomalias congênitas no exame post mortem, através da técnica de FISH, em imprints celulares de fígado. Para tanto, foram colhidos imprints de 11 casos de necropsias, fixados em dois diferentes fixadores: metanol-ácido acético (3:1), por 45 segundos, e etanol $95 \%$ por 10 minutos. Antes de proceder à técnica de FISH, foi realizado um prétratamento com ácido-acético a 70\%, por 2 minutos. A técnica de FISH foi realizada utilizando-se sondas alfa-centroméricas dos cromossomos 13/21, 18 e X. Os resultados mostraram que a utilização dos imprints de fígado para a técnica de FISH foi adequada, não havendo diferenças em relação ao sexo, idade e tempo de morte dos indivíduos. Além disso, os imprints são fáceis e rápidos de serem coletados e fixados, apresentando núcleos em número suficiente para a análise interfásica, separados, íntegros e em monocamada, o que propiciou uma análise relativamente rápida e bastante confiável. Quanto aos fixadores, não houve diferença entre os dois utilizados.

Portanto, o emprego de imprints de fígado fixados em etanol $95 \%$ constitui uma forma de preparação celular adequada para análise citogenética molecular (FIS) e tal protocolo poderá ser adotado na investigação de anomalias congênitas no exame post mortem pelo Departamento de Patologia da FMRP-USP

\section{PEDIATRIA}

\begin{abstract}
ESTUDO DA VELOCIDADE DE CRESCIMENTO E CONCENTRAÇÕES SÉRICAS DE FATOR DE CRESCIMENTO INSULINA-SÍMILE (IGF-I) E DA PROTEÍNA CARREADORA DE IGF (IGFBP)-3 EM PACIENTES COM DEFICIÊNCIA DE HORMÔNIO DE CRESCIMENTO EM REPOSIÇÃO HORMONAL
\end{abstract}

Renata Ribeiro de Moraes

Orientador Prof. Dr. Carlos Eduardo Martinelli Jr.

Dissertação de Mestrado apresentada em 22/07/2002
Durante a puberdade ocorre aumento da secreção do hormônio de crescimento (GH), com conseqüente aceleração da velocidade de crescimento e das 
concentrações de IGF-I e IGFBP-3. Acredita-se que o aumento de secreção de GH se deva à ação de esteróides sexuais e que o aumento de IGF-I seja secundário, principalmente, à alteração na secreção de $\mathrm{GH}$. O tratamento com GH recombinante proporcionou melhora importante da estatura final dos pacientes com deficiência de GH. Atualmente utiliza-se a dose de $0,1 \mathrm{U} / \mathrm{kg} / \mathrm{dia}$, independente da idade ou estágio puberal do paciente. Desta forma não se mimetiza o aumento fisiológico de GH que ocorre na puberdade. Este estudo teve como objetivo avaliar se a dose de reposição de rhGH atualmente utilizada seria suficiente para proporcionar aos pacientes com DGH velocidade de crescimento e concentrações séricas de IGF-1 e IGFBP-3 semelhantes as de indivíduos normais no mesmo estágio puberal.

Avaliou-se a velocidade de crescimento, estágio puberal e concentrações séricas de IGF-I e IGFBP3 em 34 pacientes com DGH em reposição com rhGH (40 avaliações-período). Os pacientes foram divididos de acordo com o estágio puberal: 15 eram pré-púberes (G1), 10 em puberdade inicial (G2/G3), e 15 em puberdade tardia (PT). O grupo PT foi subdividido em subgrupos G4 (5 avaliações-período) e G5 (10 avaliações-período). Foram calculados os escores de desvio padrão (EDP) da velocidade de crescimento (EDP VC), do IGF-I (EDP IGF-I) e da IGFBP-3 (EDP IGFBP-3) em relação à idade cronológica (IC), idade óssea (IO) e idade estimada para o estágio puberal (EP).

A velocidade de crescimento analisada para o estágio puberal (EDP VC EP) foi nos pacientes prépuberes igual a $1,09 \pm 2,88 ; 2,20 \pm 3,21$ nos pacientes em puberdade inicial e $\neg 4,28 \pm 1,69$ nos em estágios puberais tardios, havendo diferença entre o grupo PT e os demais. Considerando-se o EDP VC IO, o menor valor foi observado no subgrupo G4 $(-4,27 \pm 3,17)$ havendo diferença significativa entre este e os demais grupos.

As concentrações séricas de IGF-I dos pacientes quando comparada aos controles em estágio puberal semelhante foi menor nos grupos G2/G3 (154,8 $\pm 101,1$ vs. $328,1 \pm 108,1 \mu \mathrm{g} / \mathrm{L})$ e PT $(344,2 \pm 220,1$ vs. $443,1 \pm 57,04 \mu \mathrm{g} / \mathrm{L})$. Considerando-se apenas o subgrupo G4 o valor medio de IGF-I foi 190,6 $\pm 165,7$ $\mathrm{ng} / \mathrm{ml}$ para os pacientes e $453,8 \pm 26,72 \mu \mathrm{g} / \mathrm{L}$ para os controles. O grupo G2/G3 e subgrupo G4 apresentam tambem menor EDP IGF-I IO $(-0,91 \pm 0,95$ e $-1,87 \pm$ 1,12 , respectivamente) que os demais grupos. As concentrações séricas de IGFBP-3 foram menores que às dos controles em todos os estágios puberais quer considerando-se os valores absolutos quer o EDP IC. Entretanto, não foi observada diferença significativa entre a relação molar IGF-I/IGFBP-3 entre pacientes e controle nos diferentes estágios puberais.

A observação de menor VC coincidente com concentrações mais baixas de IGF-I em determinadas fases da puberdade sugere que as concentrações de IGF-I refletem melhor que a relação molar IGF-I/ IGFBP-3 o fenômeno que se processa ao nível da cartilagem de crescimento. Nossos dados permitem concluir que os pacientes com DGH em reposição com a dose usual de rhGH não alcançam velocidade de crescimento e concentrações séricas de IGF-I e IGFBP-3 semelhantes às da população normal durante a puberdade, sugerindo que a dose de rhGH deva ser titulada individualmente principalmente durante a puberdade.

\section{SAÚDE NA COMUNIDADE}

\section{ESTUDO DA DISTRIBUIÇÃO DOS MARCADORES SOROLÓGICOS DAS HEPATITES B E C ENTRE OS DOADORES DE SANGUE DO HEMOCENTRO DE RIBEIRÃO PRETO, SP}

\section{Vanderléia Bárbaro Valente}

Orientador: Prof. Dr. Afonso Dinis Costa Passos

Dissertação de Mestrado apresentada em 18/12/2002

Este estudo, que envolveu todos os doadores de sangue (25.891) que compareceram pela primeira vez ao Hemocentro de Ribeirão Preto, de junho de 1996 a junho de 2002, teve os seguintes objetivos: 1) Estudar a positividade de marcadores sorológicos das hepatites $\mathrm{B}$ e $\mathrm{C}$ em testes da triagem dos doadores. 2) Analisar o fluxo dos doadores positivos para os marcadores das hepatites B e C ao Ambulatório de Hepatites (AH) do Hospital das Clínicas da Faculdade de Medicina de Ribeirão Preto. 3) Estimar a prevalência de 
infecção atual ou pregressa pelos vírus das hepatites B e C entre os doadores, através da análise dos resultados de testes confirmatórios para essas doenças. 4) Avaliar a importância da determinação da transaminase glutâmico-pirúvica (TGP) como marcador indireto de infecção pelos vírus das hepatites B e/ou C. Foram levantados dados registrados no Hemocentro, no Núcleo de Vigilância Epidemiológica (NVE) e no AH, coletando-se informações referentes ao doador, ao tipo de doação e ao resultado de teste da triagem sorológica (HBsAg, anti-HBc, anti-HCV, TGP, anti-HIV, antiHTLV, doença de Chagas e sífilis). Foram estudados ainda: os resultados dos testes de repetição - realizados no Hemocentro - dos doadores positivos para os marcadores das hepatites $\mathrm{B}$ e $\mathrm{C}$ na triagem sorológica; o comparecimento ao NVE; e a confirmação, no AH, dos resultados para esses marcadores. A população dos doadores foi composta majoritariamente por homens $(83,6 \%)$ e indivíduos de 26 a 45 anos de idade
$(64,0 \%)$. Predominaram as doações vinculadas $(85,4 \%)$, e as maiores motivações foram solicitação e estímulo familiar ou de amigos. Os valores da prevalência, nos testes da triagem sorológica, foram iguais a $0,63 \%\left(\mathrm{IC}_{95 \%}: 0,54-0,72\right)$, para o HBsAG e $1,15 \%$ $\left(\mathrm{IC}_{95 \%}: 1,02-1,28\right)$, para o anti-HCV. O total de doadores positivos que deveriam ser avaliados no $\mathrm{AH}$, sofreu uma perda de 55,5\% entre os suspeitos de ter hepatite B e de $58,7 \%$ entre os suspeitos de ter hepatite $\mathrm{C}$, totalizando 266 doadores perdidos quanto ao acompanhamento. Os valores da prevalência, nos testes confirmatórios, foram iguais a $0,22 \%\left(\mathrm{IC}_{95 \%}: 0,16\right.$ $0,28)$, para a hepatite $\mathrm{B}, \mathrm{e} 0,31 \%\left(\mathrm{IC}_{95 \%}: 0,24-0,38\right)$, para a hepatite $\mathrm{C}$. As co-positividades entre os valores de TGP e os marcadores de hepatites, nos testes de triagem sorológica, foram de $8,8 \%$, para o vírus $\mathrm{C}$, e de $0,5 \%$, para o vírus $B$, indicando que a determinação dessa enzima não auxilia na seleção de doadores em banco de sangue.

\section{SAÚDE MENTAL}

\section{INSERÇÃO DO TERAPEUTA OCUPACIONAL EM UM HOSPITAL GERAL UNIVERSITÁRIO - SUA PARTICIPAÇÃO EM UM SERVIÇO DE CONSULTORIA PSIQUIÁTRICA}

\section{Heloisa Cristina Figueiredo Frizzo}

Orientadora: Profa. Dra. Maria Auxiliadora Campos

Dissertação de Mestrado apresentada em 15/07/2002

O presente estudo objetiva resgatar a história da implantação da assistência em Terapia Ocupacional no Hospital das Clínicas da Faculdade de Medicina de Ribeirão Preto da Universidade de São Paulo (HCFMRP-USP) com ênfase na inserção da terapeuta ocupacional no Serviço de Consultoria Psiquiátrica. Para a consecução dos objetivos propostos utilizou-se a pesquisa documental e a história oral. Os resultados apontam que até inicio de 1998, o HCFMRP-USP contava apenas com três vagas para terapeutas ocupacionais, (psiquiatria [02], ortopedia [01]. Desde de 2000, vem contando com 15 profissionais. Esta expansão pareceu decorrente e da influência da presença da Terapia Ocupacional através de estagiários, aprimorandos e profissionais voluntários, nas enfermarias e nos serviços especializados e da valorização da abordagem multidisciplinar e das competências sugeridas pelo Sistema Único de Saúde para os hospitais gerais. No período contemplado por este estudo, novembro de 1996 a outubro de 1997, foram atendidas em Terapia Ocupacional pela Consultoria Psiquiátrica 84 pessoas, o que correspondeu a 97 pedidos de interconsulta (ICP) e 53\% do total solicitado. Destas $20,6 \%$ foram à óbito, fato este que aponta para a gravidade dos casos atendidos. A maioria das solicitações de interconsulta foi proveniente da nefrologia/ UTR, neurologia, nutrologia, pediatria e ortopedia. Os principais motivos de ICP foram relacionados a sintomas psiquiátricos dos pacientes e a dificuldades vivenciadas pela equipe e no manejo de situações. Os resultados são sugestivos de que havia espaço para a inserção do terapeuta ocupacional neste hospital geral, embora algumas dificuldades tenham ocorrido. Sua presença amplia as possibilidades de intervenção tanto a nível curativo como preventivo, além de otimizar a qualidade da intervenção hospitalar, o que contribui para uma assistência que contempla não apenas a doença e sim a pessoa em sua totalidade. 


\section{ADAPTAÇÃO PARA O PORTUGUÊS DE MÉTODO DE AVALIAÇÃO DE ESTADOS SUBJETI- VOS DE CONSCIÊNCIA QUE ACOMPANHAM O RECONHECIMENTO PARA USO EM PA- CIENTES COM ESQUIZOFRENIA}

Marcos Aurélio Martins Ribeiro

Orientador: Prof. Dr. Luiz Alberto Bechelli Hetem

Dissertação de Mestrado apresentada em 29/11/2002

A memória, função cognitiva que não apenas representa e organiza a história de um individuo, mas também influi seu modo de perceber, sentir, pensar e reagir, não é mais considerada fenômeno unitário. Uma série de evidências tem mostrado que é composta por muitos sistemas e processos, e que o reconhecimento pode ser acompanhado por dois estados subjetivos de consciência qualitativamente diferentes: consciência autonoética, a qual caracteriza a rememoração consciente, e consciência noética, relacionada com sentimentos de familiaridade.

O objetivo deste estudo é descrever o processo de adaptação para o Português de um método experimental para investigação dos estados de consciência que acompanham o reconhecimento. Inicialmente é introduzida a evolução histórica desta abordagem e uma revisão da literatura sobre os diversos testes a que foi submetido e que tornaram válido. A seguir, apresentase revisão sucinta sobre as alterações de memória na esquizofrenia, incluindo os estudos em que se empregou este método experimental de auto-avaliação dos estados de consciência que acompanham a rememoração em pacientes com esquizofrenia.

O trabalho prático consistiu no desenvolvimento do material (lista de palavras e instruções que per- mitem manipulação do nível de processamento das informações por ocasião da fase de aprendizagem), da tradução/adaptação das instruções originais para o português e da aplicação do material em voluntários sãos e pacientes com esquizofrenia. A manipulação do nível de processamento de informações consistiu em solicitar, na fase de aprendizagem, que o sujeito formasse frases ou contasse as letras das palavras apresentadas. O efeito nível de processamento é fenômeno bem documentado em voluntários sãos. Sua expressão, no presente estudo, seria maior rememoração consciente (avaliada por resposta "eu me lembro") para as palavras para as quais se solicitou que se formasse frases do que para as quais se pediu que contassem as letras. Além disso, não deveria haver mudança digna de nota na proporção de reconhecimentos baseados em sentimento de familiaridade (avaliado pelas respostas "eu sei"). O procedimento foi aplicado primeiramente em seis voluntários sãos, nos quais reproduziuse nitidamente o efeito nível de processamento. Num segundo momento, foi aplicado em seis pacientes com esquizofrenia, que compreenderam perfeitamente as instruções e foram capazes de realizá-lo com solicitado. Neles também evidenciou-se o efeito nível de processamento.

Os resultados indicam que o método adaptado para o português é passível de utilização, inclusive em pacientes com esquizofrenia, permitindo assim o estudo das alterações de memória associadas a este transtorno mental.

\section{TOCOGINECOLOGIA}

\section{INDUÇÃO DA APOPTOSE EM TUMORES DE MAMA SOB QUIMIOTERAPIA NEOADJUVANTE: COMPARAÇÃO ENTRE DOIS ESQUEMAS TERAPÊUTICOS}

\section{Daniel Guimarães Tiezzi}

Orientador Prof. Dr. Jurandyr Moreira de Andrade

Dissertação de Mestrado apresentada em 30/08/2002

A quimioterapia de indução é uma opção atualmente aceita para o tratamento do câncer de mama localmente avançado. Estudos demonstram uma taxa de resposta objetiva em torno de 60 a $80 \%$ e uma forte relação entre a resposta objetiva e a sobrevida global. As taxas de apoptose e a expressão do gene p53 parecem ser indicadores da resposta e podem ter relação com a resistência tumoral aos agentes antiblásticos e radiação ionizante. O objetivo deste trabalho foi o de verificar as alterações na porcentagem de células em 
apoptose após exposição aos agentes quimioterápicos mais utilizados no tratamento neoadjuvante do carcinoma localmente avançado da mama. Outro objetivo é o de relacionar as alterações na taxa de apoptose com a resposta clínica e a expressão da proteína p53. Materiais e Métodos: foram avaliadas 49 pacientes com câncer de mama localmente avançado submetidas à quimioterapia neoadjuvante. O grupo FEC $(n=26)$ foi tratado com 5-fluoruracil, epirrubicina e ciclofosfamida e o grupo TE $(n=23)$ tratado com docetaxel e epirrubicina. A resposta clínica objetiva foi observada em $69,2 \%$ no grupo FEC e em $91,3 \%$ no grupo TE ( $p=$ 0,07). Foram avaliados o Índice Apoptótico (IA) e a expressão da proteína p53 antes e após a quimioterapia de indução e suas relações com a resposta clínica. O IA foi estimado através da contagem de células em apoptose, morfologicamente identificadas em lâminas coradas com hematoxilinaeosina, em relação ao número total de células neoplásticas aferidas. Aexpressão da proteína p53 foi avaliada através de reação imunohis- toquímica com anticorpo monoclonal. Resultados: o IA médio nas pacientes com resposta objetiva antes da quimioterapia, foi de 0,86 no grupo FEC e 0,74 no grupo TE e, após a quimioterapia, os valores foram de 1,9 e 11,5 respectivamente $(p=0,0005$ e $p=0,0002)$. Nas pacientes sem resposta clínica, não se observou diferença significante $(\mathrm{p}=0,64)$. $\mathrm{O}$ aumento de 0,03 no índice apoptótico após a quimioterapia associa-se com a resposta clínica com sensibilidade de $94,4 \%$, especificidade de $71,4 \%$ e acurácia de $89,3 \%$ (OR 45,0 IC $95 \%$ 5,1 a 395). Não se observou relação entre a expressão da proteína p53 com a resistência à indução da apoptose $(p=0,93)$ e com a resposta clínica observada $(\mathrm{p}=0,69)$. Conclusão: o aumento da porcentagem de células em apoptose está fortemente relacionada à resposta clínica à quimioterapia neoadjuvante no câncer de mama localmente avançado. A expressão da proteína p53 não foi um indicador importante na resistência ao tratamento neoadjvante nem associa-se com a indução da apoptose in vivo.

\section{EFEITOS DA METFORMINA NA AVALIAÇÃO CLÍNICA E METABÓLICA EM MULHERES COM SÍNDROME DOS OVÁRIOS POLICÍSTICOS (SOP)}

\section{Laura Ferreira Santana}

Orientadora: Profa. Dra. Rosana Maria dos Reis Dissertação de Mestrado apresentada em 14/11/2002

A Síndrome dos Ovários Policísticos (SOP) ou anovulação crônica hiperandrogênica apresenta mecanismos fisiopatológicos complexos, sendo a resistência insulínica e hiperinsulinemia os principais fatores envolvidos na sua etiopatogenia. A metformina é uma biguanida que promove a melhora da sensibilidade à insulina e seu uso vem sendo estudado no tratamento da SOP. Acredita-se que essa droga promova melhora sintomática e possa prevenir complicações a longo prazo, como diabetes mellitus, contudo há controvérsias quanto à sua efetividade no tratamento da SOP. OBJETIVO: avaliação clínica e metabólica da metformina em mulheres com SOP. PACIENTES E MÉTODOS: foram selecionadas 23 mulheres com SOP, com idade de 27,20 \pm 5,02 anos (média \pm desviopadrão), sendo que 21 delas concluíram o estudo. As pacientes foram tratadas com metformina $(1.500 \mathrm{mg} /$ dia). durante 8 semanas. Foram realizadas avaliações clínicas com ênfase no padrão menstrual e nas medidas antropométricas peso, IMC, circuferência da cintura e da relação cintura-quadril (CQ), antes e após o tratamento. As avaliações hormonais e metabólicas dos possíveis efeitos da metformina foram feitas atra- vés da realização de GTT com $75 \mathrm{~g}$ de dextrose, com dosagens de glicose e insulina: perfil lipídico com dosagens de colesterol total, HDL-colesterol, triglicérides e cálculo de LDL-colesterol: dosagens dos androgênicos: testosterona, androstenediona, sulfato de dehidroepiandrosterona (S-DHEA). Foram ainda realizadas dosagens de SHBG e de IGF-1 antes e após a terapêutica. A análise estatística: a verificação da normalidade foi realizada utilizando-se o teste de Kolmogorov-Smirnov. Para a comparação de dados foi utilizado o teste " $t$ " pareado, com nível de significância de 5\%. RESULTADOS: com o tratamento com metformina foi possível observar a presença de menstruações espontâneas em $81 \%$ das mulheres. Não ocorreu diferença com relação ao peso e ao IMC. Encontrou-se diferença significativa no padrão de distribuição de gordura corporal com diminuição da medida da cintura e da relação $\mathrm{CQ}$, respectivamente de $89,36 \pm 15,23 \mathrm{~cm}$ para $87,71 \pm 15,35 \mathrm{~cm}$ e de $0,85 \pm 0,06$ para $0,82 \pm 0,07$. Foi possível observar diminuição da insulina de jejum e do índice $\mathrm{I} / \mathrm{G}$ que foi de $0,25 \pm 0,19$ para $0,18 \pm 0,11(\mathrm{p}<0,005)$, bem como melhora no QUICKI de $0,33 \pm 0,03$ para $0,35 \pm 0,04$. Ocorreu diminuição nos níveis séricos de colesterol total de $181,70 \pm 38,09 \mathrm{mg} / \mathrm{dL}$ para $167,70 \pm 30,06 \mathrm{mg} / \mathrm{dL}$ e de LDL-colesterol de $119,80 \pm 33,06 \mathrm{mg} / \mathrm{dL}$ para $97,71 \pm 23,94 \mathrm{mg} / \mathrm{dL}$ e aumento dos níveis séricos de 
HDL-colesterol de $39 \pm 8,05 \mathrm{mg} / \mathrm{dL}$ para $50,43 \pm 10,81$ $\mathrm{mg} / \mathrm{dL}$. Foram evidenciadas reduções dos níveis séricos de testosterona que foram de $63,19 \pm 50,32 \mathrm{ng} / \mathrm{dL}$ para 50,32 $\pm 13,98 \mathrm{ng} / \mathrm{dL}$. Não foram observadas diferenças com relação aos níveis séricos de SHBG, de IGF-1 e de triglicérides. Os principais efeitos colaterais relatados foram gastrointestinais (náuseas, vômitos e diarréia) e diminuíram após a segunda semana.
CONCLUSÕES: os resultados favoráveis da utilização da metformina obtidos neste trabalho como ocorrência de menstruações espontâneas, alterações no padrão de distribuição da gordura corporal, diminuição nos níveis séricos de testosterona, melhora no perfil lipídico e diminuição na insulinemia nos permitem concluir que o tratamento com essa droga traz benefícios a mulheres com SOP, com boa tolerabilidade.

\section{EFEITO DAS DROGAS ANTIRETROVIRAIS SOBRE AS TAXAS DE FERTILIDADE DE RATAS WISTAR}

\section{Ernesto Antonio Figueiró Filho}

Orientador: Prof. Dr. Geraldo Duarte

Dissertação de Mestrado apresentada em 03/12/2002

A avaliação dos agentes anti-retrovirais utilizando modelos experimentais permite testar os efeitos farmacológicos e adversos destes farmacos sobre o organismo materno e fetal. O objetivo do presente estudo foi avaliar experimentalmente os efeitos de drogas anti-retrovirais isoladas e em associação sobre as taxas de fertilidade em ratas prenhes expostas a estes farmacos, bem como o efeito perinatais nas crias. $\mathrm{O}$ estudo foi realizado no Biotério do Departamento de Clínica Médica da FMRP-USP, utilizando ratas fêmeas prenhes adultas da raça Wistar, pesando entre 200 e $230 \mathrm{~g}$. As drogas utilizadas nos experimentos foram a azidotimidina (AZT), lamivudina (3TC) e nelfinavir (NFV), com as dosagens respectivas de $25 \mathrm{mg}, 12,5$ $\mathrm{mg}$ e $97,5 \mathrm{mg} / \mathrm{dia}$, administradas isoladamente ou em associação. No total foram avaliadas sete grupos, incluindo o controle. O início da experimentação foi o dia zero da prenhez de todos os animais, independente do grupo. A forma de sacrificio dos animais foi por decapitação após 7, 14 e 21 dias de prenhez, seguida das etapas experimentais descritas.

A cesariana foi realizada imediatamente após a decapitação do animal. Uma vez aberto o útero, foram contados os fetos vivos e mortos, os quais foram retirados para anotação do sexo, pesagem dos fetos vivos e respectivas placentas. Em seguida, os cornos uterinos foram dissecados e, por observação direta, anotada a presença de reabsorções precoces e tardias (abortamentos). O número de sítios de implantação foi obtido pela soma de fetos vivos, fetos mortos e reabsorções. Em seguida, os ovários foram removidos para contagem dos corpos lúteos. Os dados obtidos foram submetidos a estudo estatístico através dos testes "t" de Student e ANOVA para variáveis paramétricas e dos testes de Mann-Whitney e de KruskalWallis para variáveis não-paramétricas. Foram consideradas diferenças estatisticamente significativas quando o valor de " $p$ " foi menor que 0,05 . Conclusões: não houve alterações significativas nas taxas de perdas préimplantação e da eficiência de implantação de ratas tratadas com anti-retrovirais isoladas e em associação. Houve aumento significativo nas taxas de perda pós-implantação nos grupos de ratas tratadas com antiretrovirais isolados e em associação. Observou-se também, redução significativa nas taxas de viabilidade fetal e número de fetos por ninhada nos animais que receberam as drogas isoladamente e associadas e houve redução do peso materno e dos fetos nos grupos tratados com 3TC, AZT+3TC e AZT+3TC+NFV. Apesar de experimental, este estudo sinaliza para a necessidade de se pesquisar outros fármacos anti-retrovirais com menor potencial histotóxico e que possam, com segurança, serem utilizados por gestantes portadoras da infecção pelo virus da imunodeficiência humana.

\section{VALORES DOS ÍNDICES DE RESISTÊNCIA, PULSATILIDADE, VELOCIDADE SISTÓLICA MÁXIMA, VELOCIDADE DIASTÓLICA FINAL E TEMPO DE ACELERAÇÃO DA ARTÉRIA CE- REBRAL MÉDIA EM FETOS DE GESTANTES CONSIDERADAS CLINICAMENTE NORMAIS AO LONGO DA GESTAÇÃO}

\section{Antonio Gadelha da Costa}

Orientador: Prof. Dr. Francisco Mauad Filho

Dissertação de Mestrado apresentada em 09/12/2002
Foi realizado estudo observacional prospectivo e longitudinal no qual 33 fetos de gestantes normais foram avaliados entre 22 e 38 semanas de gestação, 
com o objetivo de determinar os valores dos índices de resistência, pulsatilidade, velocidade sistólica máxima, velocidade diastólica final e tempo de aceleração da artéria cerebral média fetal entre 22 e 38 semanas de gestação. A idade gestacional foi determinada pela data da última menstruação e/ou pelo exame ultra-sonográfico do primeiro trimestre. Os exames ultra-sonográficos com Doppler foram feitos por um único observador que utilizou um aparelho modelo HEWLETT PACKARD - IMAGE POINT 1800, com transdutor multifreqüencial. Para a aquisição do traçado Doppler da artéria cerebral média, o indicador de amostra foi calibrado para um volume de amostra de $1 \mathrm{~mm}$ e colocado na artéria cerebral média anterior o mais próximo possível da calota craniana.
O ângulo de insonação foi mantido entre $5^{0}$ e $19^{0}$ e o filtro foi ajustado na freqüência de $50-100 \mathrm{~Hz}$. Observou-se comportamento parabólico para o índice de resistência e pulsatilidade, com menores valores nos extremos das idades gestacionais avaliadas. A velocidade sistólica máxima aumentou progressivamente ao longo da gestação. A velocidade diastólica final teve aumento progressivo a partir de 26 semanas até o termo. O tempo de aceleração msotrou aumento significativo apenas entre 26 e 30 semanas. Concluiu-se que as curvas de normalidade construídas mostraram comportamento semelhante à maioria das curvas descritas na literatura, porém, com valores diferentes, contribuindo, desse modo, para a determinação dos valores normais de cada índice estudado na nossa população.

\section{ESTUDO COMPARATIVO DO EMPREGO DO GnRH AGONISTA E ANTAGONISTA EM FERTI- LIZAÇÃO IN VITRO}

\section{Pedro Luiz Rosan}

Orientador: Prof. Dr. Rui Alberto Ferriani

Dissertação de Mestrado apresentada em 18/12/2002

Objetivo: Confirmar a capacidade de $3 \mathrm{mg}$ do Cetrorelix dose única, em prevenir a ocorrência de luteinização precoce.

Modelo do Estudo: Estudo prospectivo controlado.

Paciente(s): Pacientes inférteis submetidas a estimulação ovariana para FIV.

Intervenção (s): Uma dose única de Cetrolix 3

$\mathrm{mg}$ foi administrada na fase folicular tardia (10 pa- cientes). O Leuprolide foi escolhido como grupo controle (10 pacientes). A estimulação ovariana foi feita com HMG.

Resultado(s): Nenhum pico de LH ocorreu depois da administração do Cetrorelix. O número de oócitos e embriões, a porcentagem da taxa de fertilização e gravidez e o número de ampolas de HMG administrada foram similar para ambos os grupos. A tolerância do Cetrorelix foi excelente.

Conclusão(s): O Cetrorelix em protocolo de dose única preveniu o pico de $\mathrm{LH}$ em todas as pacientes estudada. É comparado satisfatoriamente com o protocolo longo e pode ser um protocolo de escolha em FIV. 